\title{
A History of Research to Develop Guidance Systems to Divert Juvenile Salmonids, Oncorhynchus spp., from Turbines at Federal Hydroelectric Dams on the Mainstem Columbia and Snake Rivers, U.S.A.
}

\author{
JOHN G. WILLIAMS and MICHAEL H. GESSEL
}

\section{Background}

Pacific Northwest's Columbia River drains a watershed of 680,000 $\mathrm{km}^{2}$, and historical flows in the lower river ranged from 1,400 to 28,300 $\mathrm{m}^{3} / \mathrm{s}$, with the peak flows primarily resulting from glacial and snow melt (Williams and Tuttle, 1992). It also historically produced the largest number of Chinook salmon, Oncorhynchus tshawytscha, in the world (Netboy, 1980). Chapman (1986) estimated the peak combined adult return to the river of all salmonids, Oncorhynchus spp., in the late 1800's was approximately $8.9 \mathrm{M}$ fish, comprised of 0.6 $\mathrm{M}$ spring, $2.5 \mathrm{M}$ summer, and $1.3 \mathrm{M}$ fall Chinook salmon; $2.6 \mathrm{M}$ sockeye salmon, O. nerka; $0.6 \mathrm{M}$ coho salmon, O. kisutch; $0.6 \mathrm{M}$ steelhead, $O$. mykiss; and $0.7 \mathrm{M}$ chum salmon, $O$. keta. Craig and Hacker (1938) detailed the tremendous decline in adult returns from the late 1800 's into the

John G. Williams and Michael H. Gessel are retired from the Northwest Fisheries Science Center, Seattle, WA 98112, National Marine Fisheries Service, NOAA, U.S. Department of Commerce. Corresponding author is John G. Williams, Affiliate Professor, University of Washington, School of Aquatic and Fishery Sciences, Seattle, WA 98195 (jgw3@uw.edu).

doi: https://doi.org/10.7755/MFR.80.2.3

ABSTRACT-Eight large Federal hydropower dams were constructed between the 1930 's and 1970's on the mainstem lower Columbia and Snake Rivers, U.S.A. The dams included fishways that enabled effective upstream passage of adult salmonids to Snake River basin spawning areas, but they lacked any facilities for protection of juvenile salmonids migrating downstream to the ocean. Prior to completion of the dam complex, early studies on mortality of juvenile salmon passing through turbines suggested that Snake River salmon stocks 1930's and ascribed the majority of declines to overfishing, habitat destruction, and damming of tributaries for water withdrawal and small-scale hydropower.

The first mainstem dam (Fig. 1) on the Columbia River was completed at Rock Island, Wash., in 1933 and contained one fish ladder for upstream migrant adult salmon. This dam and the proposed dams to follow added another factor to consider when developing actions to limit the declines in fish stocks: the need to have adequate fish passage for the multitudes of fish runs that migrated up the river before turning into tributaries.

By the time Rock Island Dam was completed, the primary focus was on Bonneville Dam because of its planned location on the lower Columbia River (Fig. 1). Without effective fish passage measures in place at the time of its completion, it would potentially block and eliminate all salmon stocks and species in the river above it (Griffin, 1935).

Griffin (1935) noted that adult fish passage facilities would need to work immediately when the dam became operational because no time existed to conduct experiments to determine what type of facilities would work best.

could not survive the cumulative mortalities to populations of fish that would have to pass downstream through turbines at all eight dams. This led to a more than 30-yr field effort conducted primarily by NOAA's National Marine Fisheries Service personnel to devise, test, and recommend for installation effective screening systems for turbine intakes at dams to decrease mortality of downstream migrating juvenile salmonids. This paper provides a history of the extensive research to accomplish this goal.
At most, nearly all migratory salmon stocks in the river had only 4 or 5 adultreturn year classes, so that even 1 or 2 yr without effective passage would seriously deplete stocks of fish. Thus, prior to construction of Bonneville Dam, tremendous efforts went into design of fish lifts, fish ladders, and collection channels with large amounts of flow. All were directed toward attracting returning adult salmon to the passage facilities that provided pathways to pass fish above the dam. Despite the concerns about fish passage at Bonneville Dam and designs of fish ladders to address them, nearly concurrent construction of Grand Coulee Dam (completed in 1941) on the upper Columbia River was begun, and due to its height (167 $\mathrm{m})$, no fish facilities were considered for installation at the dam.

After completion of Bonneville Dam (Fig. 2) in 1938, studies immediately began to evaluate its effect on adult fish passage. In the adult ladders, 1 or 2 pools were modified to add a white board on the floor. When fish passed into the pool and over the board, personnel located above the pool could identify and count, by species, the fish passing up the ladder. The fish counts, rates of passage, and comparison of counts to upstream and downstream fisheries indicated that the ladders worked well (at least for salmon) (Holmes and Morton, 1939). Griffin (1935) speculated correctly that wing walls to divert downstream adult salmon and juvenile migrants to fish ladders and away from the power channel would not work. Several sluiceways installed near the spillway to attract and pass juvenile and adult fish downstream also failed and were subsequently abandoned. 


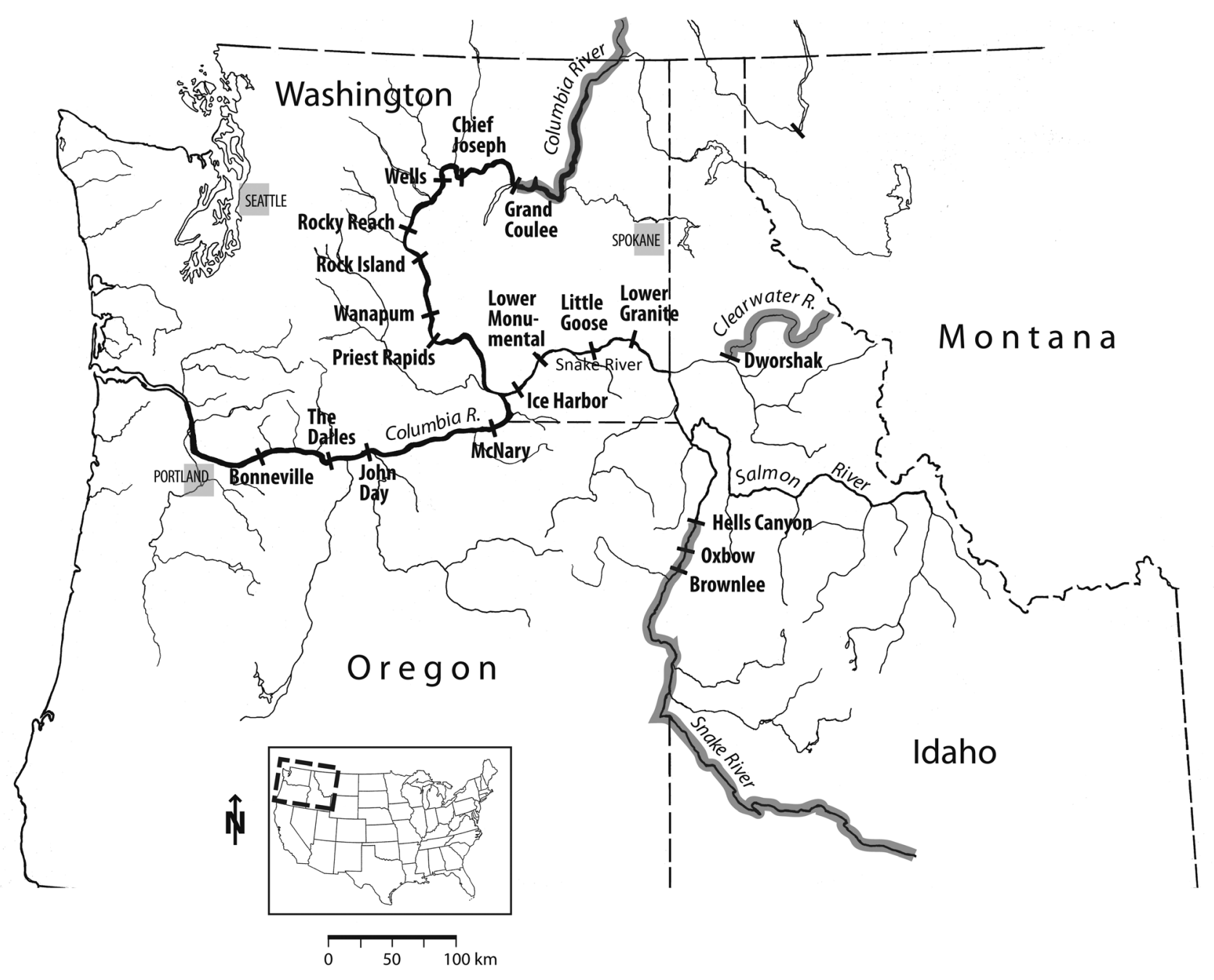

Figure 1.-Mainstem Columbia River Basin dams. Shaded areas indicate dams with no upstream fish passage facilities and extirpation of salmon runs. Chronological order of dam construction: 1933 - Rock Island; 1938 - Bonneville; 1941 - Grand Coulee; 1953 - McNary; 1955 - Chief Joseph; 1957 - The Dalles; 1958 - Brownlee; 1959 - Priest Rapids; 1961 - Ice Harbor, Rocky Reach, Oxbow; 1963 - Wanapum; 1967 - Hells Canyon, Wells; 1968 - John Day; 1969 - Lower Monumental; 1970 - Little Goose; 1974 - Dworshak; 1975 - Lower Granite; 1982 - Bonneville Dam Second Powerhouse.

While it was relatively easy to count adult fish moving upstream through the fish ladders at Bonneville Dam and relate passage to estimated river flows, the sheer size of Bonneville Dam and the size of the individual turbines made observing fish passing downstream through the dam nearly impossible, except for a small number of juveniles collected in surface collection traps (Gauley et al., 1958). Lower Columbia River flow during the peaks of the downstream migration generally ranged from $4,000-5,000 \mathrm{~m}^{3} / \mathrm{s}$ in low- flow years and up to $10,000-14,000$ $\mathrm{m}^{3} / \mathrm{s}$ in high-flow years (Raymond, 1979).

The Bonneville powerhouse is 182 $m$ wide and contains 10 Kaplan $^{1}$ turbine units, each about $15 \mathrm{~m}$ wide and which can pass up to about $375 \mathrm{~m}^{3} / \mathrm{s}$ of flow. The spillway is another $365 \mathrm{~m}$ wide. Thus, the total linear distance at the dam through which downstream migrants can pass is so large that sam-

${ }^{1}$ Mention of trade names or commercial firms does not imply endorsement by the National Marine Fisheries Service, NOAA. pling the area was not initially attempted. Because a large proportion of spill was expected to occur during periods of peak migration, it was expected that that large numbers of salmonid smolts (size range of 75-165 $\mathrm{mm}$ fork length) would pass through the spillway (with unknown effects) during periods when discharge exceeded powerhouse capacity (Griffen, 1935).

Without direct observations of downstream migrating fish, studies of the effects of turbines and spill on downstream juvenile salmon were begun 


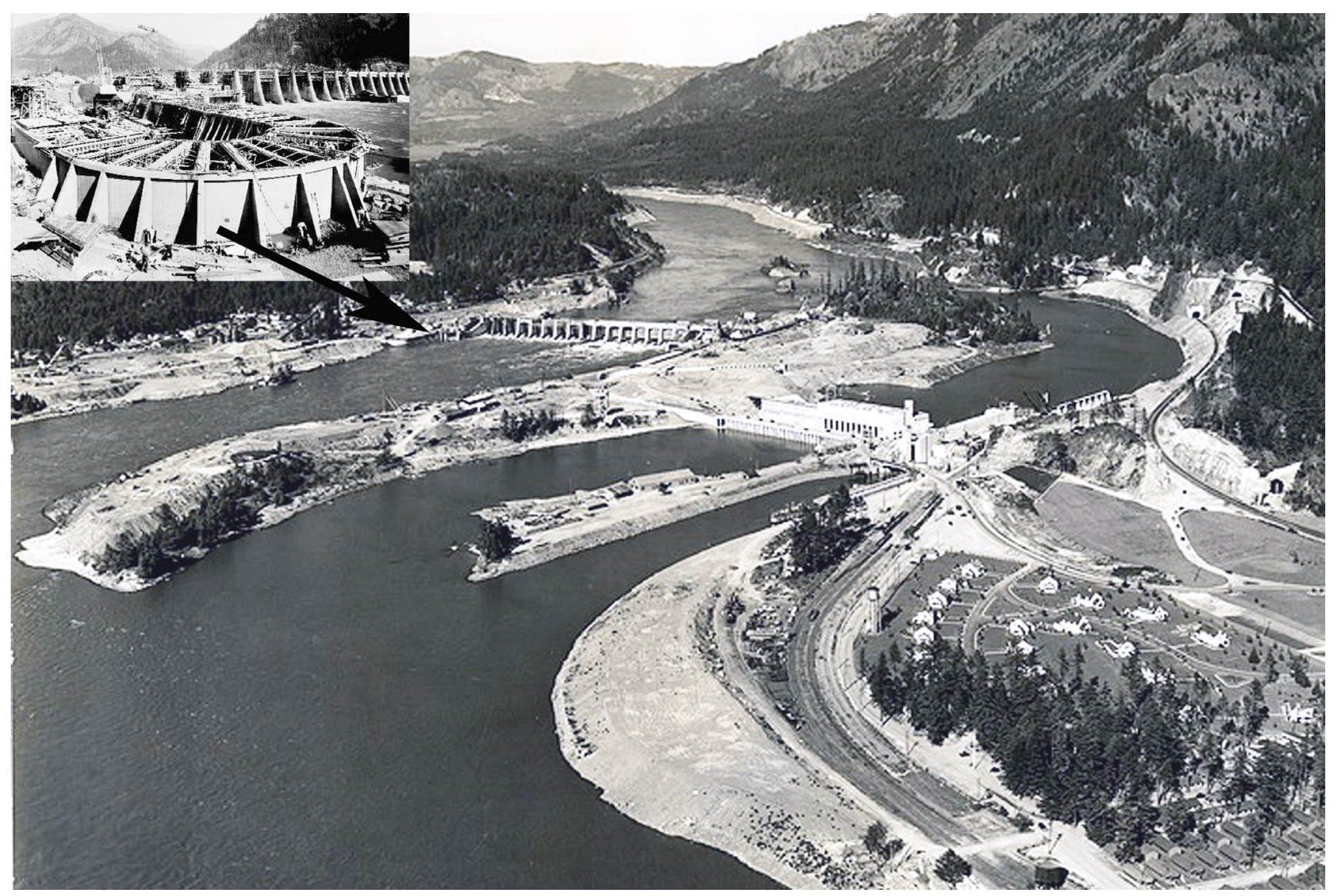

Figure 2.- Aerial view of Bonneville Dam First Powerhouse, spillways, and fish ladders near completion.

using large numbers of juvenile Chinook salmon taken from the Bonneville Hatchery. Fins were clipped and fish were released through hoses into the turbines and spillways (treatments) and tailrace (control) over several years beginning in 1938 (Holmes ${ }^{2}$ ). Adult returns to the hatchery from the different groups were compared in subsequent years.

Notes from the work indicated a bias in return rates may have existed due to different combinations of fin clips used to mark juvenile fish. Adults of juveniles with pectoral clips returned at lower rates than some other fin-clip

${ }^{2}$ Holmes, H. B. 1952. Loss of salmon fingerlings in passing Bonneville Dam as determined by marking experiments. Unpubl. in-house rep., 62 p. U.S. Dep. Inter., Fish Wildl. Serv, Bur. Commer. Fish. Portland, Oreg. [on file at NOAA, NWFSC Library, Seattle.] combinations. Nonetheless, in general, based on adult returns, juvenile fish released into turbines had mortality rates 5-6 times higher than juvenile fish that passed downstream through spillways.

At the end of WWII, with the U.S. economy improving, plans for many additional dams in the Columbia River basin were made. Often, justification for new dams relied more on political support for construction than on a direct need for additional power production (Dietrich, 1995). Five additional dams were constructed on the mainstem Columbia and Snake Rivers in the 1950's, eight in the 1960's, two in the 1970's, and an additional powerhouse was added to Bonneville Dam in the early 1980's (Fig. 1).

Of the dams built in the 1950's, Chief Joseph did not have fish pas- sage facilities because construction of Grand Coulee Dam 15 yr earlier, just $82 \mathrm{~km}$ upstream, had blocked all fish passage. Brownlee Dam on the Snake River also had no upstream passage facilities; thus, none were included at Hells Canyon and Oxbow dams when they were constructed. This led to extinction of native runs above Hells Canyon on the Snake River.

In the 1950's and 1960's, considerable research was conducted on upstream passage through ladders at experimental facilities located within laboratories at Bonneville Dam and those results led to improvements in adult passage facilities at dams already in place as well as development of new configurations subsequently installed as new dams were built (Collins et al., 1963; Gauley and Thompson, 1963; Monk et al., 1989). 

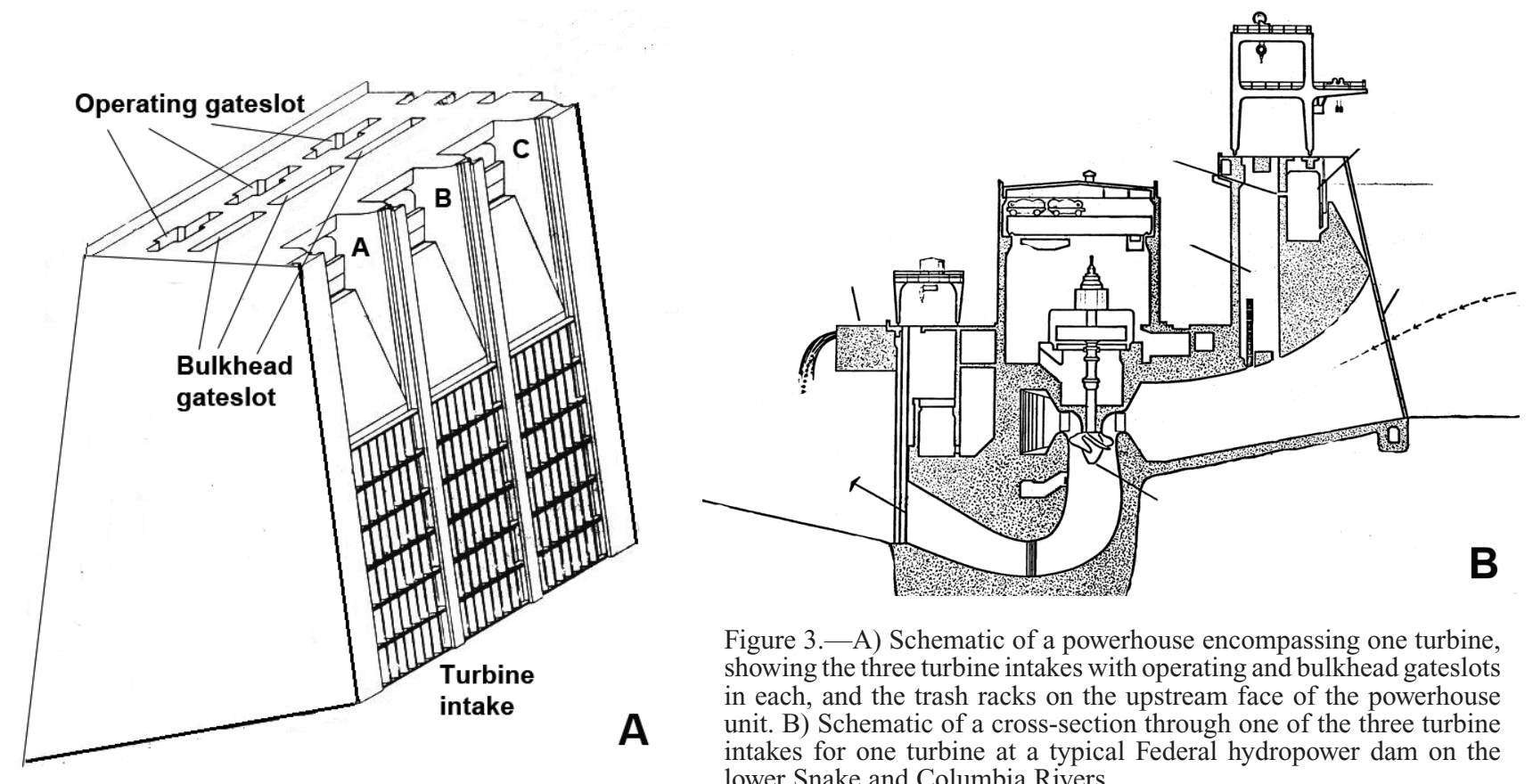

Figure 3.-A) Schematic of a powerhouse encompassing one turbine, showing the three turbine intakes with operating and bulkhead gateslots in each, and the trash racks on the upstream face of the powerhouse unit. B) Schematic of a cross-section through one of the three turbine intakes for one turbine at a typical Federal hydropower dam on the lower Snake and Columbia Rivers.

After the completion of McNary Dam in the early 1950 's, a more rigorous evaluation was made to estimate the effects of passage through turbines and spill on juvenile salmonids (Schoeneman et al., 1961). Results of this research were similar to the earlier Bonneville Dam studies_-juvenile fish passing through spillways survived at about 98\%; whereas, fish that passed through turbines survived at about $89 \%$.

These survival study results provided great concern about how well salmon stocks in the upper Columbia and Snake River basins would survive once all planned dams in the lower mainstem rivers were constructed. Dams constructed after Bonneville Dam had greater numbers of turbine units; thus, a greater percentage of river discharge would go through the turbines. Discharge was envisioned to occur through spillways only under the highest flows at most new dams. With at least eight mainstem dams that juvenile fish would need to pass, direct passage survival through turbines as fish passed eight dams was expected to lead to less than $40 \%\left[(0.89)^{8}=0.39\right]$ survival of juveniles migrating from the Snake River to below Bonneville Dam.
In the late 1950's, the Bureau of Commercial Fisheries (BCF) founded a field station in Weiser, Idaho, with the charge to begin studying the effects that Brownlee Dam on the Snake River would have on passage of juvenile and adult salmon and steelhead above and below the dam. When the first studies indicated deleterious effects would occur, a broader mandate was given in 1961 by Interior Secretary Stuart Udall. He originated a Fish Passage Program (FPP) to investigate problems of fish passage at high-head dams and develop solutions for the proposed dams in the mainstem of the lower Snake River (Trefethen, 1968).

Other BCF investigations on adult and juvenile fish passage at dams that were already underway were rolled into this larger FPP mandate. A subpart of these investigations was research to alleviate mortality of juvenile salmonids that entered turbine intakes at dams. While the research began in earnest in the early 1960's, earlier studies in the 1940's and 1950's provided some of the initial information needed on which to plan studies on fish movement in the river and into turbines. Here, we provide the history of more than $30 \mathrm{yr}$ of research begun in the 1960's that led to the development of screening and bypass systems for juvenile salmonids at Federal Columbia River hydropower dams.

\section{Dam Structure}

To understand how the research to develop guidance systems evolved requires an understanding of the basic structure and configuration of turbine intakes at the powerhouses of Federal dams on the lower Columbia and Snake Rivers; all of which were designed, built, and are operated by the U.S. Army Corps of Engineers (USACE). Each powerhouse on the lower Snake River has six turbine units. On the lower Columbia River, the number of turbine units varies among powerhouses: 8 at Bonneville Dam Second Powerhouse, 10 at Bonneville Dam First (the original) Powerhouse, 22 at The Dalles Dam, 16 at John Day Dam, and 14 at McNary Dam.

All powerhouses have vertical Kaplan turbines. The size of individual turbine bays at all dams is relatively the same; however, turbine output varies depending on the decade of turbine installation, the hydraulic head of the 
dam, and power production when operated within $1 \%$ of peak efficiency.

The flow through each turbine generally ranges between 280 and 595 $\mathrm{m}^{3} / \mathrm{s}$ when operated within $1 \%$ of peak efficiency. Newer dams generally have turbines with higher discharge capabilities. Due to the size of the turbines, structural limitations require that at the upstream face of the dam each individual turbine requires three turbine intake entrances through which water flows toward the turbine (Fig. 3a.) Water flows through trash racks with horizontal spaces of about $1 / 4 \mathrm{~m}$ width that limit large objects from entering the turbines.

While all entrances have the same dimension, because of the flow pulled through the turbine by spinning blades, the proportion of flow into the three entrances varies. About 33\% of the flow goes into the middle entrance $(\mathrm{B}$ : intake in figure), while (looking downstream), the entrance to the left (A: intake in figure) passes about $36 \%$ of the flow and the one on the right about $31 \%$. Since the entrances all have the same cross-sectional area, the velocity of water into the three turbine intakes also varies in direct proportion to the percentage of flow into the intake. Water flowing through the three turbine intakes converges into a single mass downstream of the three operating gateslots. It then flows through the wicket gates and over the turbine blades (sometimes called the runner) and discharges into the tailrace.

Powerhouses at Columbia River dams are not solid masses of concrete. Above each of the three turbine intakes is a large gatewell with two rectangular openings at the deck level and at the turbine ceiling intake level (Fig. 3b.). These openings create two vertical slots that in plan-view are about $6 \mathrm{~m}$ wide $\times 2 \mathrm{~m}$ deep. In the upstream slot (called the "bulkhead gateslot" in this paper) channel indents exist on the long axis into which it is possible to place concrete bulkheads to block flow into the turbine. The downstream slot provides the space for an operating gate and is referred in this paper as the "operating gateslot."

Bonneville (first powerhouse)

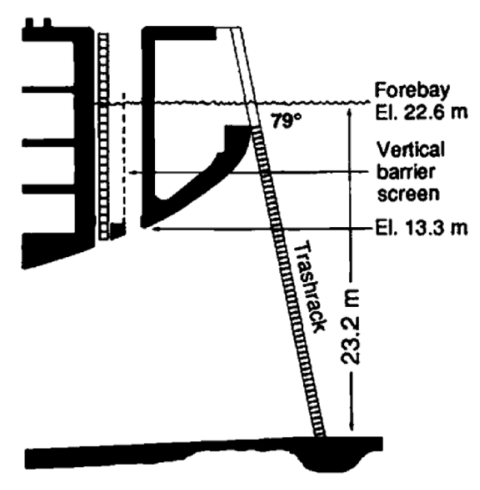

\section{The Dalles}

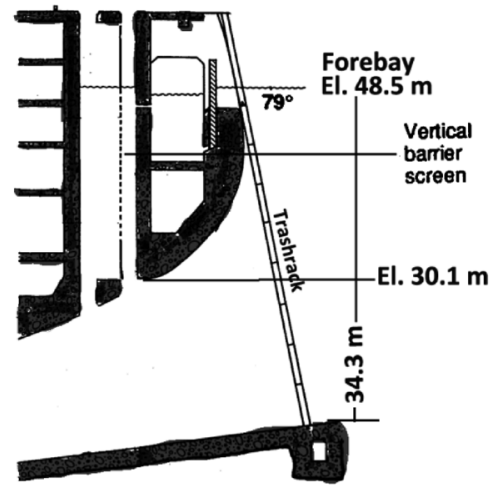

McNary

Ice Harbor
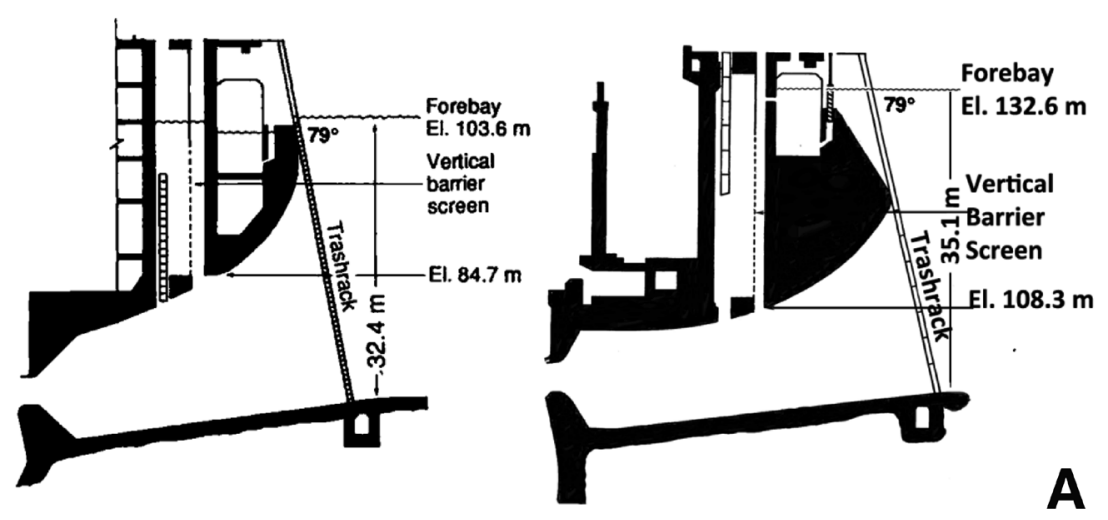

Figure 4.-A) Schematic cross-sections through the four powerhouses constructed with an ice and trash sluiceway across the forebay side (earliest powerhouses of the Federal hydropower dams on the lower Snake and Columbia Rivers). B) (facing page) Schematic cross-sections through the five powerhouses constructed without an ice and trash sluiceway across the forebay side (most recent powerhouses of the Federal hydropower dams on the lower Snake and Columbia Rivers).

At most dams each operating gateslot of each turbine intake contains a hydraulically controlled, or cabled operating gate that in case of an emergency can be lowered quickly to the bottom of the intake to stop water flow into the turbine. If no barriers exist in the bulkhead gateslot, water enters the gatewell to the level (or nearly that) of the forebay. When the turbine is operating and neither gateslot has a barrier, a small percentage of water entering the turbine intake passes up into the gatewell via the bulkhead gateslot and exits the gatewell via the operating gateslot.

The size of the structural masses of concrete at the bottom and top of the gatewell vary between powerhouses (Fig. 4.) The vertical height of the gatewell and porosity of vertical barrier screens (discussed below) influences the amount of water flowing into the gatewell when the turbine is operating.

In addition to different sized gatewells, the profile of the turbine intake ceilings at the nine Federal hydropow- 


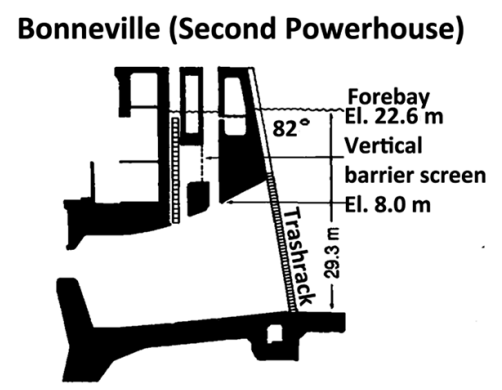

Lower Monumental

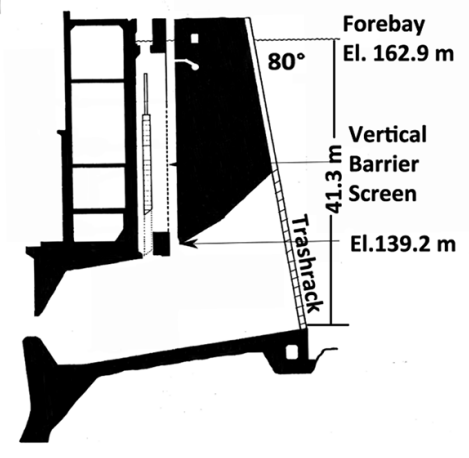

Lower Granite

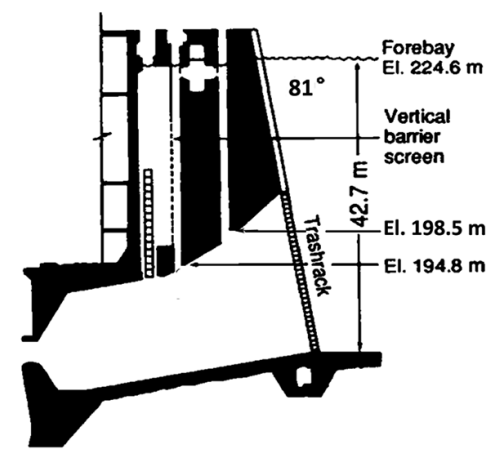

er dams on the lower Snake and Columbia Rivers has two general shapes (Fig. 4). The powerhouses constructed at Bonneville First Powerhouse, The Dalles, McNary, and Ice Harbor dams in the 1930's to early 1960's have ice and trash sluiceways built into the upstream side of the powerhouse and the ceilings of the turbine intakes curve upward from the bulkhead gateslot to a point relatively close to the forebay water level and just below the ice and trash sluiceway. The powerhouses constructed at Lower Granite, Little Goose, Lower Monumental, John Day,
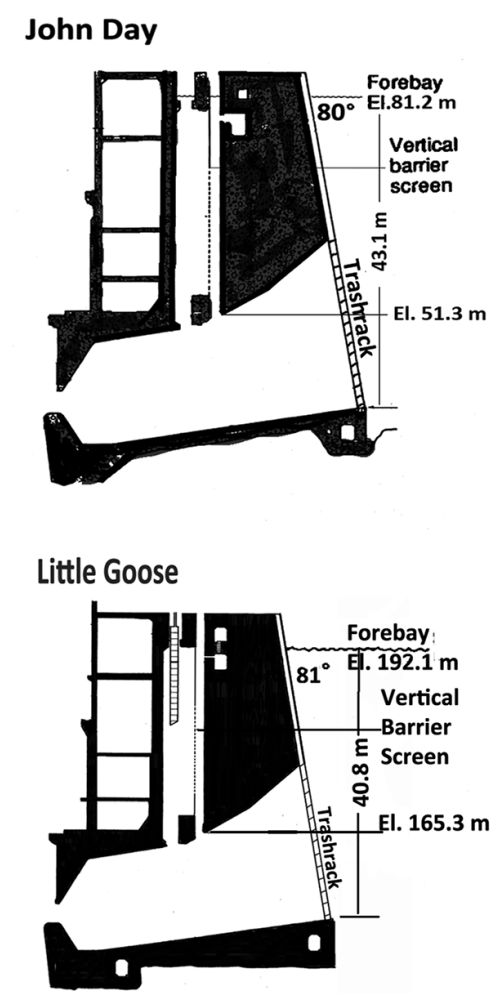

\section{B}

and Bonneville Second Powerhouse dams from the late 1960 's to 1980 's have no ice and trash sluiceways above the turbine intakes; they have flat and relatively steep faces on the upstream side of the dams, and relatively flat turbine intake ceilings that intercept the forebay reservoir at a water depth of approximately $10 \mathrm{~m}$ below the forebay level.

Phase 1: Early Research on Juvenile Fish at Dams, 1946-68

Research in 1947-48 at Bonneville Dam determined the vertical distribu- tion of juvenile salmon entering the forebay based on data collected from nets fished across the powerhouse from the surface to about $17 \mathrm{~m}$, in 3 $\mathrm{m}$ increments $\left(\right.$ Burner $\left.^{3}\right)$. While the results had variability and indicated that juvenile salmonids could be captured at any depth, they indicated that fish were more often near the surface. Studies conducted concurrently with traps in the auxiliary water systems between 1946 and 1953 determined that migrants tended to pass in greatest numbers at dusk and dawn (Gauley et al., 1958).

An auxiliary observation from the early years of collecting juveniles at Bonneville Dam was that during periods of high river discharge (about early April to late June) woody debris and small salmon were entrapped in the top of the gatewells of operating turbine units. Since little water flowed into gatewells compared to the volume flowing into turbine intakes, this observation suggested that fish possibly entered the gatewell while trying to swim toward the surface and avoid the bulk of water flowing deeper into the turbine unit. This led to directed research in 1959 to quantify the numbers of smolts in gatewells at Bonneville Dam (Long $\left.{ }^{4}\right)$. At Bonneville Dam in one 5-day period, nearly 6,500 fish were removed from one gatewell. The research was replicated at McNary Dam in 1961. Fish were removed from gatewells in test units with a large dipnet (Bentley and Raymond, 1968), sorted by species, and counted. Over 9,500 fish were removed from gatewells at McNary Dam in a 13-day period. Research-

${ }^{3}$ Burner. C. J. 1949. Vertical distribution of downstream migrating Chinook salmon fingerlings in the Bonneville forebay, with a note upon the rate of migration. Unpubl. in-house rep. U.S. Dep. Inter., Fish Wildl. Serv, Bur. Commer. Fish. Portland, Oreg. [on file at University of Washington Allen Library (SH222.W32 B87).]

${ }^{4}$ Long, C. W. 1964. Occurrence of fingerling salmonids in turbine intake gatewells. Rep. No. 50, In Collins, G. B., and C. H. Elling (Editors), Fishpassage research program review of progress 1964 , 7 p. Volume IV, Rep. of the Accelerated Fish-Passage Research Program to the Bur. Commer. Fish., Seattle. [avail. at https://www.nwfsc.noaa.gov/ assets/4/6692_10242016_132412_Long.1964FPR-IV-50.pdf]. 


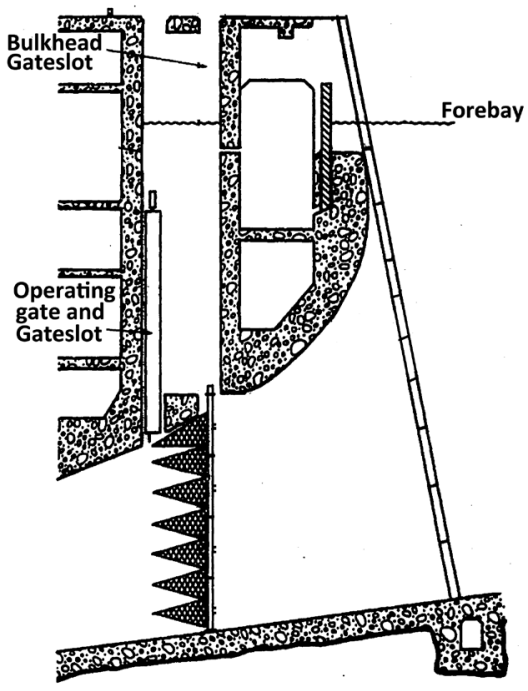

Figure 5.- Schematic of a typical fyke-net configuration to determine vertical distribution of fish entering a turbine intake. In early years three columns of nets were generally used to cover the entire intake area. In later years, only the center column contained nets. Various net dimensions were used in some years to better define the vertical distribution that was potentially intercepted by various screen lengths. Nets were generally placed in the bulkhead gateslot, but were sometimes placed in the operating gateslot, particularly when testing extended-length screens.

ers concluded that since fish naturally moved into gatewells from the turbine intakes, efforts should begin to find means to increase the number of fish entering gatewells, determine a means to keep them in the gatewells so that they would not pass back into the turbine intake, and develop a method to divert fish from the gatewells to a nonturbine route past the dam.

Also in this decade, research on screening methods to divert juvenile migrant fish was conducted at the Tracy Pumping Station on California's Sacramento River (Bates and Vinsonhaler, 1957). Results of this research indicated that horizontal traveling screens did not attain high diversion percentages but they suggested the possibility that screens with a traveling mesh could divert fish from a turbine intake.
In 1960 and 1961, Long (1968) used fyke nets placed vertically within turbine intakes (Fig. 5) to study the temporal and vertical distribution of fish in turbine intakes at McNary and The Dalles dams. Recoveries of fish indicated that if the majority of salmonids were in the upper one-third of the intake, they would most likely pass through turbines near the hub so that improving passage conditions near the hub might increase turbine survival, and that the use of deflection and bypass techniques near ceiling intakes might deflect a high percentage of fish entering the turbine intake. He also confirmed earlier findings from sluiceway studies at Bonneville Dam that most juveniles passed into the turbines between dusk and dawn. Related to the studies to determine vertical distribution of fish at McNary Dam, additional research was conducted to see if lights in the forebay at the dam would change the vertical distribution of fish passing into the turbine intake (Long ${ }^{5}$; Fields ${ }^{6}$ ). The research by Long ${ }^{5}$ indicated they did not. Another behavioral study evaluated an electrical curtain as a means to possibly move fish away from deleterious passage routes (Pugh et al., 1970), but results from the 1962 research indicated that electrical screens did not have much feasibility to guide salmonids in water velocities greater than $0.3 \mathrm{~m} / \mathrm{s}$. In addition to the fact that river velocities often exceeded this rate, it seemed infeasible to develop an electric array in the large forebay expanses at dams on the Columbia or Snake Rivers.

${ }^{5}$ Long, C. W. 1964. Effect of lighted conditions at a surface bypass on the vertical distribution of fingerling salmonids in a turbine intake (summary). Rep. No. 51, In Collins, G. B., and C. H. Elling (Editors), Fish-passage research program review of progress 1964, $4 \mathrm{p}$. Volume IV, Rep. of the Accelerated Fish-Passage Research Program to the Bur. Commer. Fish., Seattle. [avail. at https://www.nwfsc.noaa.gov/ assets/4/6690_10242016_142536_Long.1964FPR-IV-51.pdf ].

${ }^{6}$ Fields, P. E. 1966. Final report on migrant salmon light guiding studies (contr. rep. D.A.-45-108 CIVENG-63-29) at Columbia River dams, 267 p. Rep. to Fisheries Engineering Research Program, U.S. Army Engineer Division, North Pacific Corps of Engineers, Portland, Oreg.
Several years later, Monan et al. (1969) found that juvenile Chinook and coho salmon migrated in higher proportions in the outer one-third of the river than in the middle one-third, and generally the majority were in the upper one-third of the water column. As with early studies at Bonneville Dam, fish were detected from the surface to the bottom of the river. More importantly related to potential juvenile bypasses, the fish were also mixed with a large amount of debris. The authors concluded that to collect most juvenile salmonids arriving at a dam would require straining nearly the entire water mass, and it would require a method capable of coping with large quantities of debris.

By 1964, the general consensus among BCF researchers was that they would, in the short-term, follow a dual path on addressing passage of fish through turbines at dams. The first was to determine if it were possible to improve survival through turbines by altering operations, and if successful, determine if altered operations were feasible when needs of power were considered. The second was to determine the feasibility of using screens, behavioral devices, or a combination of both that would attract or divert fish into the gatewells as fish passed into the turbine intakes, all the while dealing with the debris load in the river during the migration period.

Based on the earlier vertical distribution research at The Dalles and McNary Dams (Long, 1968), in 1964, the first proposal was made to use diversion screens within turbine intakes to divert fish into gatewells at dams $\left(\right.$ Long $\left.^{7}\right)$. Four different potential means to increase the percentage of juveniles entering the gatewell were proposed: 1) raise the operating gate to increase the flow into the gatewell

${ }^{7}$ Long, C. W. 1964. Increasing the percentage of fingerlings entering intake gatewells - a proposal. Rep. No. 56, In Collins, G. B., and C. H. Elling (Editors), Fish-passage research program review of progress 1964, 3 p. Volume IV, Rep. of the Accelerated Fish-Passage Research Program to the U.S. Bur. Commer. Fish., Seattle. [avail. at https://www.nwfsc.noaa.gov/ assets/4/6691_10242016_150033_Long.1964FPR-IV-56.pdf]. 
through the bulkhead gateslot, 2) lower the operating gate into the turbine intake to block the path of fish passing near the turbine intake ceiling, 3) insert a screen down the bulkhead gateslot that would extend into the turbine intake, and 4) place a screen on the front of the trash rack to divert fish higher into the water column.

To obtain basic information for the design of a suitable fish guiding device, the $\mathrm{BCF}$ constructed a model at the Fisheries-Engineering Research Laboratory at Bonneville Dam that simulated a segment of a turbine intake and gatewell. Equipment tested in this structure included baffles, expanded metal plates to modify flows and fish behavior, and a diversion screen (VanDerwalker, 1970; Marquette and Long, 1971).

Between 1962 and 1968, BCF also conducted field research at Bonneville Dam (Long and Marquette ${ }^{8}$ ) and at Ice Harbor Dam (Long et al. ${ }^{9}$ ) to determine the effect of turbine passage on juvenile fish and whether it looked feasible to manipulate turbines to alter survival. Results from the 1968 Ice Harbor Dam studies indicated significant mortality from predation for fingerlings that ended up in the backroll area of the tailrace after they had passed through turbines (Long et al. ${ }^{9}$ ). Thus, BCF researchers concluded that even if turbines were made sufficiently safe, the best approach to protect fish would be a system to bypass fish around turbines in order to avoid high predation on fish exiting turbines. Therefore, all efforts turned toward de-

\footnotetext{
${ }^{8}$ Long, C. W., and W. M. Marquette. 1964. Program of research on fingerling passage problems associated with Kaplan turbines, 1962-64. Rep. No. 43, In Collins, G. B., and C. H. Elling (Editors), Fish-passage research program review of progress 1964, 22 p. Volume IV, Rep. of the Accelerated Fish-Passage Research Program to the U.S. Bur. Commer. Fish., Seattle. [avail. at https://www.nwfsc.noaa.gov/ assets/11/6697_10242016_124820_Long.and. Marquette.1964-FPR-IV-43.pdf ]

${ }^{9}$ Long, C. W., R. F. Krcma, and F. J. Ossiander. 1968. Research on fingerling mortality in Kaplan turbines-1968. Fingerling Passage Program, Prog. Rep. Bur. Commer. Fish., Seattle, 7 p.[avail. at https://www.nwfsc.noaa. gov/assets/26/7335_07232012_125411_Long. et.al.1968.pdf ].
}

veloping systems to divert fish away from turbine intakes into gatewells at dams.

Consensus of researchers was to try a diversion screen. Long and Krcma (1969) developed an initial proposal to install and test a "juvenile salmonid bypass system" at Ice Harbor Dam. They envisioned putting self-cleaning traveling screens down the bulkhead gateslots that would protrude into the flow within the turbine intake and divert juveniles into gatewells (Fig. 3 ). The rationale for a self-cleaning screen was based on the large amount of debris that entered the reservoir at Ice Harbor Dam and built up along the face of the dam. Although the dam had an ice and trash sluiceway to facilitate moving ice and trash to the tailrace of the dam, the debris nonetheless had already shown a propensity to move into gatewells. Near the top of each gatewell, a submerged orifice would connect to the ice and trash sluiceway which discharged through a chute into the tailrace of the dam.

The orifice placement was based on research at Ice Harbor Dam in 1965 where the optimum placement of an elliptical $56 \mathrm{~cm} \mathrm{x} 46 \mathrm{~cm}$ orifice was submerged $1.5 \mathrm{~m}$ deep and located in the corner of a gatewell (Liscom, 1971), plus additional research on prototype $15.2 \mathrm{~cm}$ diameter orifices installed in the center intakes of Turbine Units 5, 8, and 11 at McNary Dam and tested in 1968 (Bentley and Raymond, 1969).

Efficiency of the orifices to pass fish out of gatewells was called orifice passage efficiency (OPE). It was initially determined by comparing the number of fish removed from the gatewells with and without orifices. A hinged dip basket (Bentley and Raymond, 1968), sometimes called a butterfly dip basket because with the two sides open the basket looked somewhat like it had butterfly wings, was used to remove fish from the gatewells.

At McNary Dam, the combined OPE of all salmonids was generally greater than $80 \%$. Based on these results, prior to the 1969 migration season a single $15.2 \mathrm{~cm}$ diameter orifice was installed $0.5 \mathrm{~m}$ from the north corner in the remaining gatewells for the 14 turbine units at the McNary Dam and in all of the gatewells for all operating turbine intakes at Ice Harbor Dam. The research also led to installation of $15.2 \mathrm{~cm}$ diameter orifices at John Day (1969), Lower Monumental (1969), and Little Goose (1971) dams (Smith and Farr, 1975). The newer dams did not have integral ice and trash sluiceways, so the orifices emptied into conduits mined within the dams that channeled water to a release site in the tailrace of the dam.

With the exception of the initial preliminary orifice research (Bentley and Raymond, 1969; Liscom, 1971), most concepts in the juvenile bypass proposal were untested. Thus, the Long and Krcma (1969) proposal contained basic questions that the research would need to address:

1) Would the traveling screens guide a sufficient proportion of the population entering the turbine intake? [Guidance rate-subsequently called "fish guidance efficiency" (FGE)],

2) Were screens structurally safe to put into the intake and would they work well mechanically for the duration of the juvenile migration? [Mechanical reliability],

3) Would traveling screens impinge fish and if impinged, would they come off the rotating screen as the screen face reached the entrance to the gatewell? [Effect of screens on fish descaling]. In the 1960 's, BCF researchers had devised a methodology and a standard to assess if a salmon was considered "descaled." The result was that a fish missing scales on $10 \%$ of its body was considered descaled. The methodology to determine descaling was detailed in a report by Basham et al. (1982). In this paper, all references to descaled fish or descaling rates of fish relied on this same methodology,

4) What percentage of fish would survive? [Survival of fish in gatewells],

5) Would fish diverted into the gatewell readily find the submerged orifices and pass into the ice and trash sluiceway? (OPE), and 
6) Would predation increase for fish concentrated by a bypass system and released into the tailrace? [Survival of fish in tailrace].

\section{Phase 2: Initial Juvenile Bypass System Implementation and Evaluation, 1969-70}

The physical structure of the intake screens was based on earlier research to develop horizontal traveling screens to divert juvenile salmonids in irrigation canals (Bates et al., 1970; Bates and Vanderwalker, 1970). Wire mesh on the outside of the screen captured debris and as the mesh rotated to the back side of the screen, the water current washed it off. For turbine intakes, as the rotating screen reached the top of the frame adjacent to the gatewell, the direction of water velocity trended toward entering the gatewell and impinged fish could move off the screen or were washed off as the screen rotated to the back side of the frame.

Before testing a prototype screen at Ice Harbor Dam, tests were conducted in a scale model of an Ice Harbor Dam turbine intake using different variants of wire-mesh porosity on screens. The tests determined how flow disruption created by the guiding device set at a $45^{\circ}$ angle to the perpendicular frame affected hatchery fish released into the model. The screens with the least porosity diverted the most fish. For field tests, screens designed for turbine intakes were inserted vertically into the bulkhead slot, the screen was lowered into the turbine intake, pendant cables were pulled to raise the screen to a $45^{\circ}$ angle, and a hydraulic pump rotated cogged wheels which rotated the mesh around the screen $\left(\right.$ Farr $\left.^{10}\right)$. Each screen was quite large, with dimensions of approximately $6 \mathrm{~m}$ wide and $6 \mathrm{~m}$ in length (Fig. 6).

The initial test of a prototype submersible traveling screen (STS) oc-

\footnotetext{
${ }^{10}$ Farr, W. E. 1973. Traveling screens for turbine intakes of hydroelectric dams. U.S. Dep. Commer., NOAA, Natl. Mar. Fish.Serv., Northwest Fish. Cent., Seattle, unpubl. rep., 20 p. [avail. at https://www.nwfsc.noaa.gov/assets/ 26/7325_07232012_110859_Farr.1973.pdf].
}

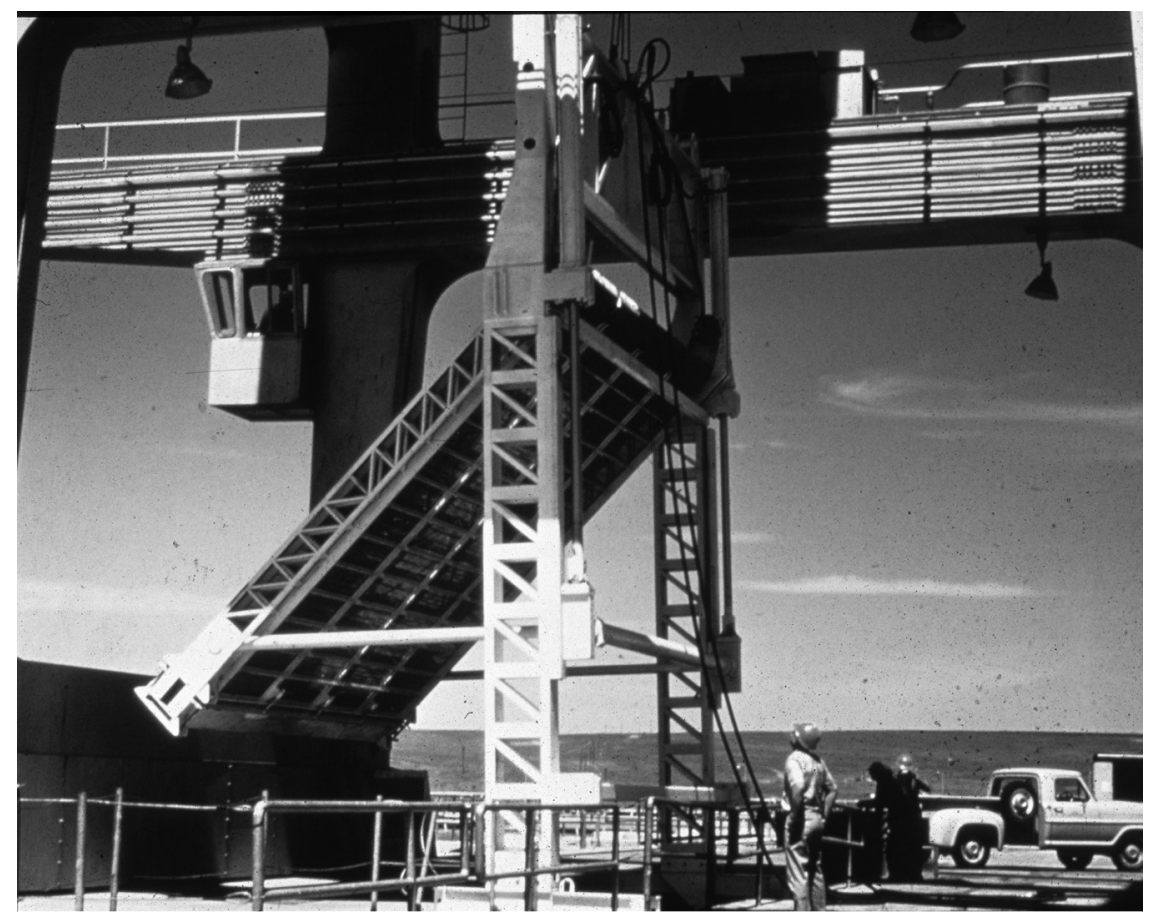

Figure 6.-Original submersible traveling screen (STS) used at Ice Harbor Dam and shown with the screen extended. While later variations of standard STS were tested with different screen materials and porosity, the overall dimensions of standard STS remained the same.

curred at Ice Harbor Dam in 1969. The primary objective of this study was to conduct mechanical tests with the device installed in an operating turbine to examine performance and to pinpoint potential problem areas. The testing was initially set for a 2 month window between early April and early June when juvenile spring-summer Chinook salmon and steelhead smolts migrated to the ocean from the Snake River. Late delivery and mechanical problems limited spring testing in 1969 to only a couple of days (Marquette et al. ${ }^{11}$ ).

Biological evaluation of the screen only occurred for two tests late in May. The effectiveness of the STS was based on a comparison of the number

\footnotetext{
${ }^{11}$ Marquette, W. M., F. J. Ossiander, R. Duncan, C. W. Long, and R. F. Krcma. 1970. Research on gatewell-sluice method of bypassing downstream migrant fish around low-head dams. Rep. to U.S. Army Corps Eng., Walla Walla District by U.S. Bur. Commer. Fish., Seattle, 32 p. [avail. at http://www.nwfsc.noaa.gov/assets/26/7146_07022012_135038_Marquette. et.al.1970.pdf ].
}

of fish removed by a hinged dip basket from the gatewells of two turbine intakes of Turbine Unit 3: one with the prototype STS (Gatewell B) and one without (Gatewell A). The tests were relative because without a barrier screen in the gatewell inserted between the bulkhead and operating gateslots, most of the fish diverted into the bulkhead slot swam out of the operating gateslot and back into the turbine intake. No obvious differences in the numbers of fish removed from gatewells in turbine intakes with or without an operating STS were found.

In the fall, the STS was operated only to evaluate mechanical reliability. The screen had a mechanical failure after 29 days. Additional tests were also conducted at McNary Dam in 1969 on the ability of fish to exit gatewells through $15.2 \mathrm{~cm}$ diameter orifices (Marquette et al. ${ }^{11}$ ). The tests indicated that a darkened gatewell that had a bright light on the downstream side of the orifice caused the least amount of retention of fish in the gatewell. Reten- 
tion within the gatewell over a $24 \mathrm{~h}$ period, however, was approximately $50 \%$ for Chinook juveniles. Little apparent mortality or descaling occurred on fish transiting the sluiceway after passing through orifices. Due to high flow conditions, no measure of survival of fish entering the tailrace was possible.

In 1970, the prototype STS was again tested at Ice Harbor Dam as were OPE tests (Long et al. ${ }^{12}$ ). More than three times as many juvenile Chinook salmon were dipnetted from the gatewell with the STS than the one without, but the numbers of steelhead were about the same. As in 1969, no barrier screen was in place within the gatewell to trap fish in the bulkhead gateslot. The greatest concern was that the percentage of fish remaining in the gatewell was much higher at Ice Harbor Dam than was found at McNary Dam the year before. Researchers concluded that a barrier screen was needed in the gatewell between the operating and bulkhead gateslots to contain fish in a confined area so that they would more readily have contact with the orifice. As for the lack of diversion of steelhead by the prototype screen, it was decided that in order to determine potential causes, research tests would require the inclusion of fyke nets below the STS to provide the ability to compare the number of fish passing above the screen with the number passing below.

The construction and operation of mainstem dams on the lower Snake and Columbia Rivers in the 1960's and early 1970 's led to a substantial decline of salmon and steelhead populations from the Snake River basin (Raymond, 1979). Thus, in addition to research to develop screening systems for turbines as a potential means to decrease mortality to downstream migrant smolts, research began on the feasibility of collecting salmonid smolts at dams and then transporting them past down-

\footnotetext{
${ }^{12}$ Long, C. W., R. F. Krcma, W. M. Marquette, and R. Duncan. 1970. Further research on a fingerling bypass for low-head dams (1970). U.S. Dep. Commer., NOAA, Natl. Mar. Fish. Serv., Seattle, unpubl. rep., 23 p. [avail. at http://www.nwfsc. noaa.gov/assets/26/7336_07232012_130019_ Long.et.al.1970.pdf ].
}

stream reservoirs and dams to avoid the cumulative mortality of migrants passing through multiple turbines in the hydropower system.

The first transportation studies were conducted during 1968-70 at Ice Harbor Dam. Juveniles were collected from gatewells by a dipnet, marked, and a portion were transported by truck to a release site below Bonneville Dam while the remainder were released at Ice Harbor Dam to continue their migration (Ebel et al., 1973).

Results from these initial studies indicated that marked and transported fish returned at higher rates than marked fish migrating downstream from Ice Harbor Dam. Because of these positive results, interest in collecting and transporting fish increased. Thus, over the next decade, the bulk of the juvenile bypass system research was focused on dams where transportation was considered a viable option: Little Goose and Lower Granite Dams on the lower Snake River and McNary Dam on the lower Columbia River.

\section{Phase 3: Development and Evaluation of

In 1971, BCF became the National Marine Fisheries Service (NMFS) under the National Oceanic and Atmospheric Administration (NOAA). All of the staff and field stations that conducted the earlier research remained the same and continued the ongoing efforts to address passage problems at dams. Evaluations of STS and orifice installations were moved upstream to Little Goose Dam with its completion in 1971 (Ebel et al. ${ }^{13}$ ). Rather than

${ }^{13}$ Ebel, W. J., H. L. Raymond, C. W. Long, W. M. Marquette, R. F. Krcma, and D. Park. 1971. Progress report on fish-protective facilities at Little Goose Dam and summaries of other studies relating to the various measures taken by the Corps of Engineers to reduce losses of salmon and steelhead in the Columbia and Snake Rivers. Report to U.S. Army Corps of Engineers, Walla Walla District by NOAA, Natl. Mar. Fish. Serv., Seattle, 40 p. [avail. at http://www.nwfsc.noaa. gov/assets/26/6607_08042010_082952_Ebel. et.al.1971a-rev.pdf ] one orifice per gatewell as was initially installed at McNary Dam, at Little Goose Dam two $15.2 \mathrm{~cm}$ diameter orifices were installed in each gatewell and each was bell-mouthed (larger diameter in the gatewell end constricting to a $15.2 \mathrm{~cm}$ diameter at the exit into the mined channel).

Three prototype STS were tested in Turbine Unit 2. This allowed screening all three intakes of one turbine unit, thus limiting the potential bias of fish moving between screened and unscreened intakes within the same operating turbine. Considerable mechanical failures of the STS during the spring migration period limited the number of feasible tests. For tests, in the center turbine intake (2B), a frame with 12 fyke nets attached was placed below the STS and a net (closure net) attached to the top of the backside of the STS frame (Fig. 7). The fyke-netframe nets were designed to capture fish diverted below the STS and the closure net to capture fish diverted above the STS (but not into the bulkhead gateslot). These latter fish were expected to include volitional migrants as well fish impinged on the STS mesh that were then dislodged as the mesh rotated to the backside of the screen.

To confine diverted fish into the bulkhead gateslots of the three turbine intakes, a vertical barrier screen (VBS) (Fig. 8) was installed between concrete masses at the top and bottom of the gatewell that separated the bulkhead and operating gateslots in each turbine intake (Fig. 3b). This configuration led to the design and construction of a new dip basket that would more efficiently remove fish diverted into bulkhead gateslots (Swan et al., 1979). For turbine units without the test STS, only one gatewell in one turbine intake had an installed VBS.

With VBS and STS installed in all turbine intakes of one turbine unit, and a new dipbasket to remove fish more efficiently from gatewells, the first formal procedures to measure the effectiveness of the STS to divert fish out of turbine intakes were developed. To conduct a test, the turbine unit was turned off and orifices in the three in- 

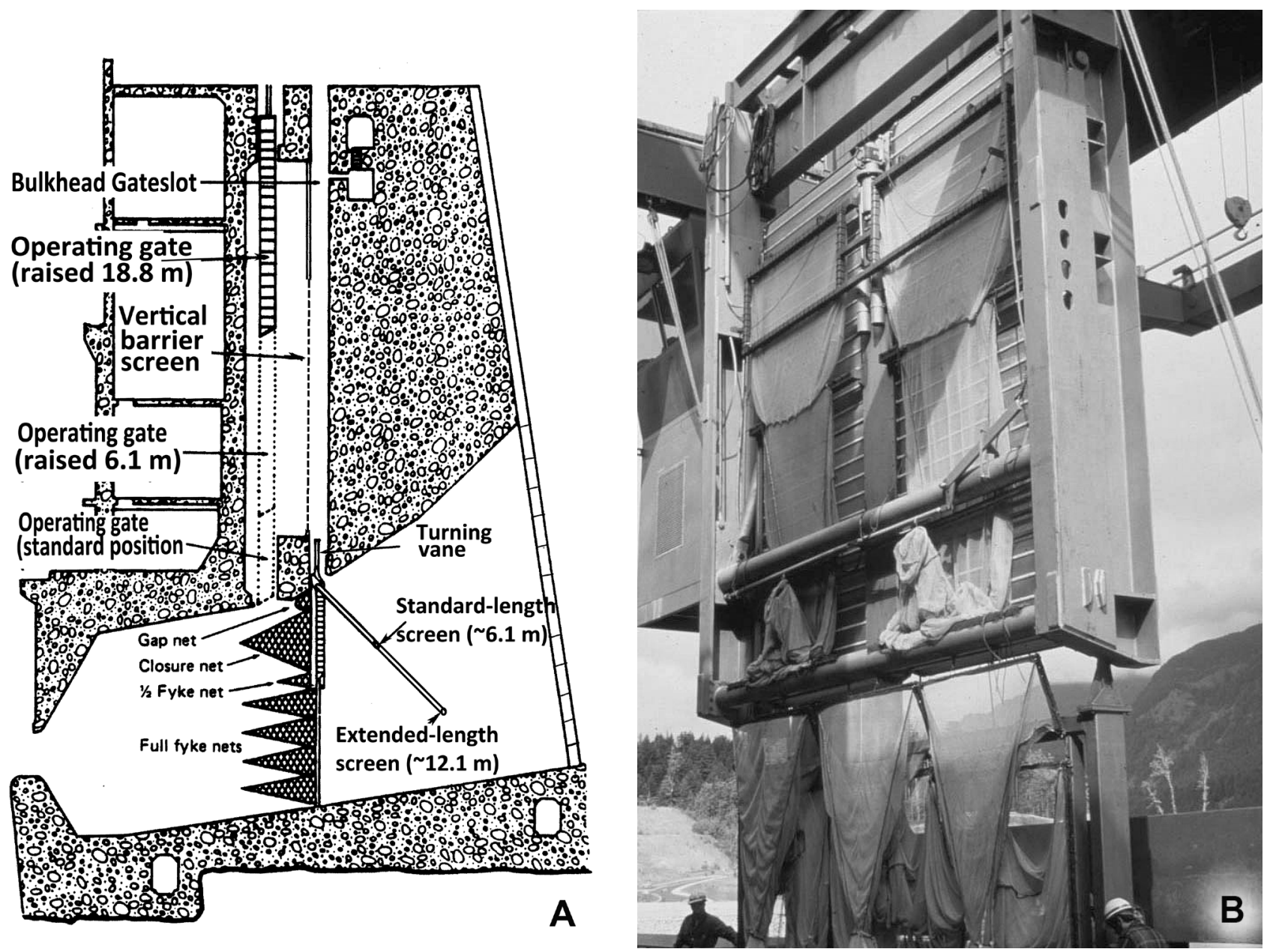

Figure 7.-A) Schematic of a turbine intake showing general configuration of a deployed standard or extended-length screen in a normal position. The identified turning vane at top of screen was not used in early years of testing. The fyke-net configuration was used for tests of standard screens. For nearly all extended screen tests, a fyke-net frame was inserted in the downstream operating gateslot. Operating gate shown in the 3 most common test configurations. B) Photograph of an STS with fyke nets behind the screen and on a portion of the fyke-net frame attached to the bottom of the STS ready to lower into the bulkhead gateslot.

takes closed. The STS with fyke-net frame attached was lowered into the center turbine intake and the dipbasket was used to remove all fish from the gatewell. The unit was then put into operation for a specified time.

To terminate a test, the turbine unit was shut off, a dipbasket removed all fish from the gatewell of the center intake, and the STS with fyke-net frame were then removed from the bulkhead gateslot. The fish captured in the fyke nets and in the closure net were counted by species, and the sum of these totals was added to the total number of fish by species removed from the gatewell. For each species and each test fish guidance efficiency (FGE) estimates were made. The FGE equaled the number of fish in the gatewell divided by the total number removed from the gatewell plus those captured in all nets.

In two tests conducted in late April, the FGE ranged from $81 \%$ to $97 \%$ for yearling Chinook salmon and steelhead, respectively $\left(\operatorname{Farr}^{10}\right)$. However, during the 1971 tests, periods of time existed when a relatively high number of fish removed from gatewells were descaled (greater than $10 \%$ of body scales missing). No obvious causes were found although it seemed possible that some fish were already descaled on arrival at the dam or became so after passing debris on the trash racks.

From the beginning of the field season, it was clear that fish accumulated in gatewells with and without VBS. Special screens to crowd fish toward the orifices were employed to speed removal of fish from gatewells, but retention of fish in the gatewells was still unacceptably high. In midMay clear plastic tubes that converted the bell-mouthed orifices to the nontapered type used at McNary Dam 


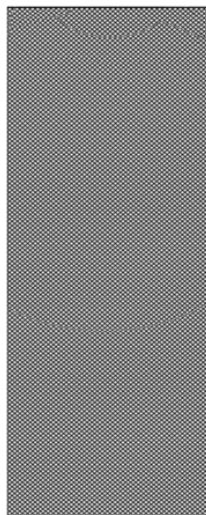

a.) Standard VBS

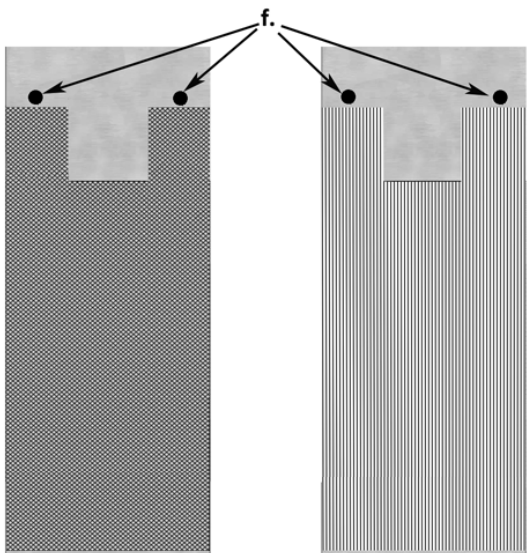

d.) Modified BFVBS

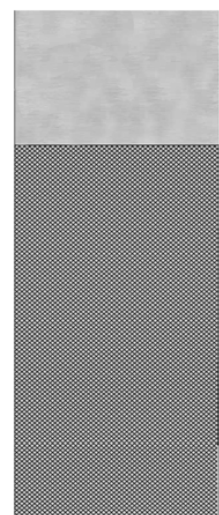

b.) Standard VBS with solid plates

e.) VBS1 and VBS2

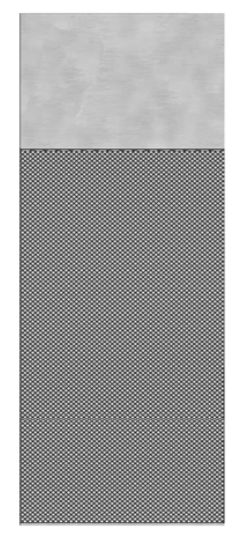

c.) Balanced flow
VBS (front side)

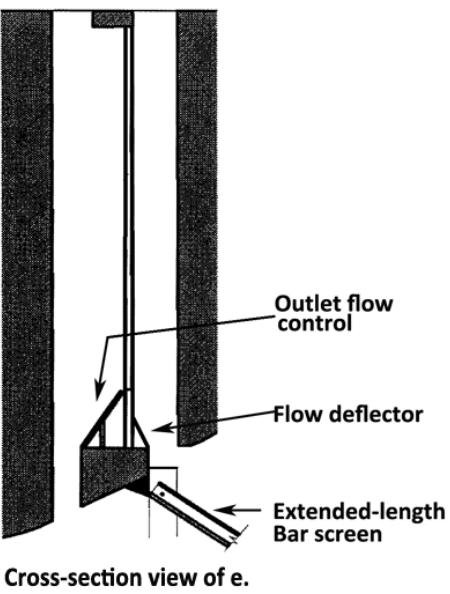

Figure 8.-Schematic of vertical barrier screen (VBS) configurations (not to scale) showing the side fish encounter when entering a bulkhead gateslot. Screens evolved over time to improve gatewell conditions. The original screens (a) had only a polyester mesh (1971-72). All VBS (b-e) had a solid panel added to the top beginning in 1973 (the size of panels varied depending on the gatewell hydraulics at the dam at which they were installed). Flow through mesh panels was balanced with the addition of perforated plate added to the downstream side of the VBS (c-e) beginning in 1982. The perforation pattern was based on gatewell hydraulics and varied among dams. These screens were termed balanced flow vertical barrier screens (BFVBS). Alteration of the solid panels on BFVBS (d) to provide additional screened flow in vicinity of orifices (f) installed through the upstream gatewell wall was first tested in 1984. Only half of the upper panel was modified if only one operating orifice existed in the gatewell. This new configuration was termed the modified-BFVBS. When testing extended length screens in 1994, VBS with upstream mesh replaced with wedge-wire screen were tested (e). [Note]: the bottom of the VBS (e) also had a deflector on the upstream side to smooth flow entering the gatewell, and a plate on the downstream side to control the overall flow into and out of the gatewell.

were inserted in gatewells with VBS. Each insert was equipped with a mercury vapor lamp so that when lit, the lamps provided illumination to the orifice exit. This change simulated the condition that worked so successfully at McNary Dam in 1969 (Marquette et al. $\left.{ }^{11}\right)$. Changing the orifices from a bell-mouthed configuration into a straight-tube configuration (Smith and Farr, 1975) improved OPE; however, when the two conditions that provided the best conditions for orifice passage at McNary Dam were tested at Little
Goose Dam, 22-41\% of fish were still in the gatewell after $24 \mathrm{~h}$; a value considerably less than satisfactory.

Because of the high FGE observed during the two 1971 STS tests, the STS related research for the next several years was directed toward the development of an STS that would reliably operate throughout a field season, specifically in the areas of the drive system, the drive chain, and different types of roller bearing material, while at the same time not injuring smolts or delaying their downstream passage. Further, because of concerns about mortality to fish captured in fyke nets and because the tests in 1971 had indicated high guidance, the majority of the tests in 1972 and 1973 did not use fyke nets underneath the STS. Instead, run-of-the-river migrants were captured either through gatewell dipping or purse seining in the forebay, marked by freeze brand, and then released through a hose (Fig. 9) into the test turbines for evaluation. While this approach eliminated the fyke-net mortality, it only provided a relative estimate of fish guidance.

During the 1972 field season, the three test STS at Little Goose Dam operated during the major period of downstream migration which was considerably longer than in 1971 , but collectively only $60 \%$ of the time (Ebel et al. $\left.{ }^{14}\right)$. Repeat of 1971 OPE tests with aluminum tubing inserts found that continued accumulations of fish in the gatewell occurred, presumably as a result from delays in fish passage through the submerged orifices and due, in part at least, to excessive turbulence in the gatewells. When turbines were shut down, turbulence in gatewells ceased and fish movement through orifices increased.

${ }^{14}$ Ebel, W. J., H. L. Raymond, C. W. Long, W. M. Marquette, R. F. Krcma, and D. Park. 1973. Evaluation of fish protective facilities at Little Goose Dam and review of other studies relating to protection of juvenile salmonids in Columbia and Snake Rivers, 1972. Progress report to U.S. Army Corps of Engineers, Walla Walla District by NOAA, Natl. Mar. Fish. Serv., Seattle, 52 p. [avail. at http://www.nwfsc.noaa. gov/assets/26/6610_08042010_084030_Ebel. et.al.1973c-rev.pdf ]. 


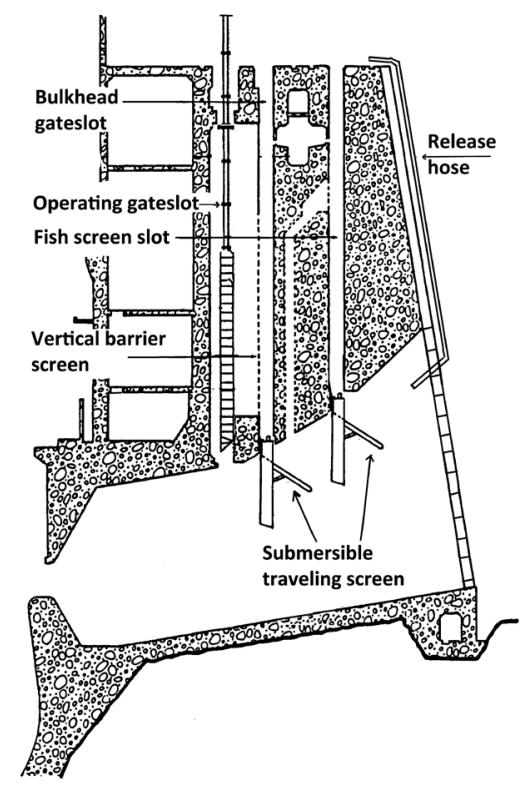

Figure 9.- Schematic of Lower Granite Dam turbine intake configuration. Release hoses were used at Little Goose and Lower Granite dams from 1972 to 1979 to evaluate FGE of STS.

Tests were conducted with a modified VBS to see if it would reduce gatewell turbulence and increase fish passage. The porosity of the VBS in gatewell 1B was decreased in two test series to change the flow pattern in the gatewell. In one set of tests, plywood sheets were attached to the upper $9.7 \mathrm{~m}$ and lower $4.8 \mathrm{~m}$ of screen, which left approximately $11 \mathrm{~m}$ of uncovered screen between the panels. For a second set of tests, only the upper $9.7 \mathrm{~m}$ of screen was covered. In the tests where both upper and lower portions of the screen were covered, it decreased flow into the gatewell by about one-half compared to conditions with an unmodified VBS. Turbulence in the gatewells was reduced, but the reduction of water inflow apparently resulted in decreased percentages of fish entering the gatewell.

When solid plates were installed only at the top of the VBS, flow entering the gatewell was not significantly reduced, while at the water surface gatewell turbulence was essentially eliminated along with an increased percentage of fish exiting through the orifices. Fish observed at the water surface of the gatewell were well distributed and swimming with much less effort than in adjacent control gatewells with unmodified VBS. Researchers recommended modifying all of the VBS at Little Goose Dam. A test of smaller STS mesh was also tried to see if it would decrease descaling, but the smaller mesh had decreased porosity which increased flow and turbulence in the gatewell. No change in descaling was seen.

In 1973, nine STS were installed at Little Goose Dam in the three operating turbine units (Ebel et al. ${ }^{15}$ ). While the screens initially worked without undue problems, high rates of descaling on fish in gatewells led to removal of six of the nine screens by 11 May. The remaining three STS were used to evaluate possible causes for the high descaling observed. Results of evaluations indicated that in gatewells with STS, an average of $13.9 \%$ of Chinook salmon smolts were descaled compared to $4.1 \%$ in gatewells without STS. Tests of different STS configurations indicated that the higher rates of descaling were related to the screenmesh size of STS and to the level of turbine unit operation; high loads (high turbine flow) caused increased gatewell turbulence and descaling.

Further, 1973 was a low-flow year, and the estimated survival of smolts migrating from Little Goose Dam to The Dalles Dam was quite low (Raymond, 1979). Based on the low survival of migrants in 1973 and the earlier results that indicated fish collected and transported from Ice Harbor Dam to a release site below Bonneville Dam had adult returns that were 50-300\% greater than fish that migrated through the river, efforts were no longer directed at developing effective release sites

${ }^{15}$ Ebel, W. J., R. F. Krcma, and H. L. Raymond. 1973. Evaluation of fish protective facilities at Little Goose Dam and review of other studies relating to protection of juvenile salmonids in Columbia \& Snake Rivers, 1973. Progress Report to U.S. Army Corps of Engineers, Walla Walla District by NOAA, Natl. Mar. Fish. Serv., Seattle, 52 p. [avail. at http://www.nwfsc.noaa. gov/assets/26/6611_08042010_084301_Ebel. et.al.1973-rev.pdf ]. of fish guided away from turbines. Instead, plans were made to transport all fish guided into gatewells from Snake River dams to a release site below Bonneville Dam.

In 1974, the STS guidance research at Little Goose Dam was focused on finding a screen mesh size in combination with or without a $48 \%$ porosity plate behind the mesh that would provide the highest guidance with acceptably low levels of descaling (Ebel et al. $\left.{ }^{16}\right)$. Field tests included combinations of different screen-mesh size and perforated plate behind the STS screen, lights placed in turbine intakes to potentially attract fish closer to the intake ceiling as a means to increase guidance and decrease descaling, and variable turbine loads.

The lowest descaling rates occurred with regular mesh backed by a $48 \%$ perforated porosity plate and at peak turbine efficiency. The same porosity plate when used with intermediate mesh (less strands of wire per surface area that created a higher surface velocity condition) led to higher descaling rates. The turbine intake water velocity increased by approximately $40 \%$ when the turbine was operated at full load. This led to lower recovery of fish in the gatewell and also higher rates of descaling. Lights on the turbine intake ceiling had no measurable effect on the percentage of fish recovered in the gatewell or the rate of descaling under full turbine load, but did lead to an approximately $10 \%$ increase in recovery under peak efficiency load.

Even with the release hose attached so that fish exited downstream of the trash racks, recovery of Chinook salmon released through the hose only ranged from approximately 50\% under full turbine load to $65 \%$ under peak turbine efficiency load. Steelhead des-

${ }^{16}$ Ebel, W. J., R. F. Krcma, D. Park, H. L. Raymond, E. Slatick, E. M. Dawley, and G. A. Swan. 1974. Evaluation of fish protective facilities at Little Goose Dam and review of other studies relating to protection of juvenile salmonids in the Columbia and Snake Rivers, 1974. Progress report to U.S. Army Corps of Engineers, Walla Walla District by NOAA, Natl. Mar. Fish. Serv., Seattle, 50 p. [avail. at http://www.nwfsc.noaa. gov/assets/26/6612_08042010_084732_Ebel. et.al.1974b-rev.pdf ]. 
caling rates were uniformly lower than for Chinook salmon while recovery rates in the gatewell were uniformly higher.

Although the research at Little Goose Dam from 1971-74 did not provide proven designs for fully operational STS systems, results appeared promising. In addition to the transportation results from Ice Harbor Dam, the early results from research at Little Goose Dam also indicated that juvenile fish transported in trucks from the dam to a release site below Bonneville Dam produced higher adult returns compared to fish that migrated through the dams in the hydropower system (Ebel, 1980). The combined results of these transportation studies and the lower survival of juvenile salmonid smolts that migrated in low-flow years increased the urgency to develop and install complete screening systems at Little Goose Dam and influenced the design of Lower Granite Dam.

Lower Granite Dam was somewhat different than at the other lower Snake River dams. To potentially avoid tying up bulkhead gateslots with an STS, a fish screen slot (FSS) was designed and built into the dam (Fig. 9.) It was envisioned to hold a STS, intercept juveniles close to the entrance to the turbine intake ceiling, and guide fish up the slot where they could pass through an orifice. The FSS had several potentially beneficial characteristics: 1) the cross sectional area of water entering the turbine intake is larger and the water velocity lower than at the entrance to the bulkhead gateslot, 2) the angle of flow approaching STS deployed in the FSS is more acute potentially lessening the chance of descaling, and 3) the ceiling of the intake on the upstream side of the FSS is cut off horizontally allowing a larger opening into the FSS than in the bulkhead gateslot with installed STS.

Similar to Little Goose Dam, the gatewell at Lower Granite Dam had a VBS with the upper $11 \mathrm{~m}$ containing a solid plate (Fig. 8b). In all turbine intakes, both the upstream wall of the bulkhead gateslot and the downstream wall of the FSS had two, 20.3 $\mathrm{cm}$ diameter orifices installed and they were modifiable to a $15.2 \mathrm{~cm}$ diameter orifice- the standard size installed at other dams. Water exiting the orifices flowed into a gallery constructed within the powerhouse structure. Although only one turbine unit was in operation at Lower Granite Dam in 1975, the majority of research related to development of STS was moved upstream to it from Little Goose Dam (Park et al. ${ }^{17}$ ). The basic design and mechanical operation of the STS had evolved to what was considered a workable piece of gear $\left(\right.$ Farr $\left.^{18}\right)$, but additional research was considered necessary to fine-tune the STS to make it both "fish friendly" and relatively maintenance free.

Research in 1975 tested STS in both the FFS and bulkhead gateslot. All screens had $48 \%$ porosity plates, two of them had regular mesh, and one screen had intermediate mesh. All tests were conducted at full turbine load. Run-of-river fish were captured from gatewells, marked, and released through hoses back into the turbine intake into an area about $1.5 \mathrm{~m}$ downstream from the trash rack and 1.5-2.0 $\mathrm{m}$ above the STS (Fig. 9.) Marked fish recovered from gatewells by dipnet provided relative recovery rates for different tests and fish were observed to determine fish condition.

The positive benefit of perforated plate backing observed at Little Goose Dam was confirmed at Lower Granite Dam in 1975. Overall average percent descaling for salmon in the bulkhead gateslots was $6.4 \%$, which was much reduced from the $21 \%$ rate recorded in previous years when there was no

\footnotetext{
${ }^{17}$ Park, D., E. M. Dawley, R. F. Krcma, C. W. Long, E. Slatick, J. R. Smith, and G. A. Swan. 1976. Evaluation of fish protective facilities at Little Goose Dam and Lower Granite Dams and review of other studies relating to protection of juvenile salmonids in the Columbia and Snake Rivers, 1975. Report to U.S. Army Corps of Engineers, Walla Walla District by NOAA, Natl. Mar. Fish. Serv., Seattle, 50 p. [avail. at http://www.nwfsc. noaa.gov/assets/26/6808_08092011_115116_ Park.et.al.1976-rev.pdf].

${ }^{18}$ Farr, W. E. 1976. Status of traveling screen development - 1976. NOAA, Natl. Mar. Fish. Serv., Northwest Alaska Sci. Cent., Seattle, 11 p. [avail. at http://www.nwfsc.noaa.gov/assets/ 26/7326_07232012_111319_Farr.1976.pdf].
}

perforated plate backing behind the screen. Nonetheless, the $6.4 \%$ descaling rate in the bulkhead slot was still considered unacceptable in the long term. Of the two mesh sizes, descaling was lower with the intermediate mesh compared to the regular.

The descaling rate of juvenile Chinook salmon and steelhead recovered from the FSS averaged about 20\%, nearly three times higher than the descaling rate of fish recovered from the bulkhead gateslot. The high descaling rate of fish in the FSS was thought to be related to the fixed $45^{\circ}$ angle of the STS and how the flow intercepted the screen face. Recommendations were made to construct a new STS that could operate at variable angles.

Additional guidance tests were conducted in fall 1975 using pre-smolt Coho salmon released through hoses in order to test two turbine loads, two mesh sizes for the screens, and plates inside the screen with two different porosities. Further, the water was clear enough to take videos of fish behavior in the area of the screens, and lights were placed at the entrance of the FSS to determine if illumination might increase guidance. It quickly became apparent that the hatchery Coho salmon did not behave the same as natural migrants nor have the same rate of descaling. They did provide some relative differences in descaling and led to the conclusion that the $33 \%$ porosity plate with the intermediate mesh size was the best combination to try in the future. The FSS continued to show large increases in descaling compared to the bulkhead gateslot. Design was in progress for screens adjustable to variable angles.

While the guidance work was not very successful, evaluation of the lighted, $20.3 \mathrm{~cm}$ diameter orifices indicated that few salmonid juveniles remained in the gatewell after $24 \mathrm{~h}$ of operation. Results were compared to passage through two $15.2 \mathrm{~cm}$ diameter orifices and the smaller orifices were again considered unacceptable because about twice as many fingerlings stayed in the gatewell compared to residual counts when two $20.3 \mathrm{~cm}$ diameter 
orifices were open. Exploratory tests indicated there was no preference for egress through the south vs. the north orifice. Further testing was deemed necessary to determine if a single 20.3 $\mathrm{cm}$ diameter orifice would be adequate for optimum passage.

In 1976, studies continued at Lower Granite Dam to evaluate standard and three new, variable-angle STS adjustable from $45^{\circ}$ to $65^{\circ}$ in $5^{\circ}$ increments and operated in either the FSS or the bulkhead slot (Park et al. ${ }^{19}$ ). The STS had two types of mesh and porosity: regular mesh backed by $48 \%$ porosity plates and an intermediate mesh backed by $33 \%$ porosity plates. Tests of both screen porosities and varying screen angles in the FFS and bulkhead gateslots found that the highest recovery rate of fish released from hoses occurred in the bulkhead slot with intermediate mesh size and 33\% porosity plates. The lowest recovery rate occurred in FSS with regular mesh and $48 \%$ porosity plate.

The new variable-angle screens had a number of mechanical problems that limited their use at times. Under the best conditions, the descaling rate on Chinook was only $3 \%$ compared to the $6 \%$ in 1975; however, steelhead descaling remained at about $6 \%$. When the screen was set at angles of $50^{\circ}$ or higher in the FSS, descaling of fish removed from the gatewell was similar to those recovered from the bulkhead gateslot. The lowest descaling rates tested under all conditions generally occurred with the $33 \%$ porosity plate behind the intermediate traveling mesh. Because of mechanical problems with the new adjustable screens, it was recommended that another year of testing was needed and that screens with lights should be tested.

\footnotetext{
${ }^{19}$ Park, D., J. R. Smith, E. Slatick, G. A. Swan, E. M. Dawley, and G. M. Matthews. 1977. Evaluation of fish protective facilities at Little Goose and Lower Granite Dams and review of nitrogen studies relating to protection of juvenile salmonids in the Columbia and Snake Rivers, 1976. Report to U.S. Army Corps of Engineers, Walla Walla District by NOAA, Natl. Mar. Fish. Serv., Seattle, 47 p. [avail. at https://www.nwfsc.noaa. gov/assets/26/7222_07092012_102141_Park. et.al.1977-rev.pdf ].
}

In 1976, further testing at Lower Granite Dam of new lighted $20.3 \mathrm{~cm}$ orifices confirmed the results obtained in 1975 - that the larger orifice worked much better than the originally installed $15.2 \mathrm{~cm}$ orifices at Little Goose Dam. Few fish remained in gatewells after $24 \mathrm{~h}$ with the former compared to $20-30 \%$ with the latter. Continued problems existed with descaling of fish collected at Little Goose Dam and much of it was thought related to fish delayed in gatewells due to inadequate orifice size. New studies were proposed to test different sized orifices in the downstream side of the gatewell (operating gate area), including mechanical controls to open and close them, prior to the spring 1977 outmigration.

In 1977, all three operating turbine units at Lower Granite Dam were screened, the first dam in the river to achieve this. Studies were planned to monitor the prolonged operation of STS equipped with intermediate mesh and $33 \%$ porosity plates in all bulkhead slots of Units 2 and 3 and to evaluate the condition of juvenile smolts within the bulkhead slots. Research was also directed at evaluation of the adjustable-angle traveling screens for guidance and descaling effects on natural migrant Chinook salmon smolts in relationship to optimum screen angle, percent open-area perforated plate, lighting condition, and to determine a preferred location for operation in either the bulkhead gateslot or the FSS (Park et al. $\left.{ }^{20}\right)$.

Similar to research results in 1976, even with new adjustable STS, screens placed in the bulkhead gateslots recovered more fish with lower descaling rates than screens placed in the FSS. An angle of $60^{\circ}$ in combination 33\% porosity screens provided conditions in which fish had the lowest rates of

\footnotetext{
${ }^{20}$ Park, D., J. R. Smith, E. Slatick, G. M. Matthews, L. R. Basham., and G. A. Swan. 1978. Evaluation of fish protective facilities at Little Goose and Lower Granite Dams and review mass transportation activities 1977. Report to U.S. Army Corps of Engineers, Walla Walla District by NOAA, Natl. Mar. Fish. Serv., Seattle, $60 \mathrm{p}$. [avail. at http://www.nwfsc.noaa. gov/assets/26/6809_08092011_115936_Park. et.al.1978-rev.pdf ].
}

descaling and the highest rates of recovery. Descaling rates in 1977 were much higher than in earlier years and the increase was attributed to the historic low flows and variable turbine operation (Williams and Matthews, 1995), not to the equipment tested. As in previous years, measures of fish guidance were based on recovery of fish released through hoses that had been inserted into the turbine intake.

New test orifices were not installed at Little Goose Dam as proposed because very low Snake and Columbia River discharge in the winter and early spring of 1977 required operation of all turbine units at Little Goose Dam for power generation; thus, delaying installation of the new orifices until mid-June - at which time smolts were no longer available to test the system. An evaluation of the system was rescheduled for 1978 .

By the start of the spring juvenile salmonid migration in 1978, STS had been installed in all six of the now operating turbine units at Lower Granite Dam (Park et al. ${ }^{21}$ ). The effectiveness of the STS was determined by periodically sampling juveniles from gatewells and measuring levels of descaling. The screens were presumed operating satisfactorily based on average descaling rates of $3 \%$ and $5 \%$ for steelhead and Chinook salmon, respectively, and because large numbers of fish were collected for transportation.

Evaluation of orifices at Little Goose Dam continued in 1978. The top two panels of the VBS were removed so that fish guided into the bulkhead slot would have access to the test orifices installed in the downstream wall of the gatewell (in the slot with the operating gate) (Park et al. ${ }^{20}$ ). Marked juvenile Chinook salmon and steelhead were released simultaneously into the bulkhead gateslot and along

${ }^{21}$ Park, D., J. R. Smith, G. M. Matthews, L. R. Basham, G. A. Swan, G. T. McCabe, T. R. Ruehle, J. R. Harmon, and B. H. Monk. 1979. Transportation activities and related research at Lower Granite, Little Goose, and McNary Dams 1978. Report to U.S. Army Corps of Engineers, Walla Walla District by NOAA, Natl. Mar. Fish. Serv., Seattle, 65 p. [avail. at http://www.nwfsc.noaa. gov/assets/26/6810_08092011_120249_Park. et.al.1979-rev.pdf ]. 
with natural-river migrants recovered $24 \mathrm{~h}$ later after passing through one of the orifice/light combinations tested. Test combinations included north and south $20.3 \mathrm{~cm}$ diameter orifices that were lighted or dark, north and south $25.4 \mathrm{~cm}$ diameter orifices that were lighted or dark, a single north $25.4 \mathrm{~cm}$ diameter orifice that was lighted, and a single south $30.5 \mathrm{~cm}$ diameter orifice.

During the tests, a special effort was made to maintain operating STS with a uniform full-turbine generating load of 155 megawatts. The test results, while not providing clear evidence for an optimum orifice arrangement did show that two lighted, $20.3 \mathrm{~cm}$ diameter orifices passed fish better than a single $25.3 \mathrm{~cm}$ or $30.4 \mathrm{~cm}$ diameter orifice. However, recovery rates of fish passing through orifices were low. This indicated that many fish passing over the top of the VBS passed down through the operating gateslot and back into the turbine rather than through the orifices. Further studies to test orifices drilled into the downstream wall of the gatewell were abandoned.

Measurements of flow direction within surface waters of gatewells indicated that different gatewells for turbine intakes $\mathrm{A}, \mathrm{B}$, or $\mathrm{C}$ (as noted earlier, each turbine intake has a different level of flow) had different flow directions. Because of continuing high descaling with the $15.2 \mathrm{~cm}$ diameter orifices, it was recommended to replace them with both a north and south $30.4 \mathrm{~cm}$ diameter orifice in each turbine intake gatewell.

In 1979 , the recovery rate of Chinook salmon and steelhead smolts captured, marked, and released in the forebay was only an estimated 31\% and $50 \%$, respectively, at Lower Granite Dam (Smith et al. ${ }^{22}$ ). This was a much lower proportion than the assumed FGE if the STS and orifices had worked correctly. Further, since

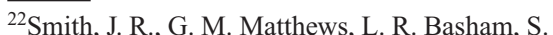
Achord, and G. T. McCabe. 1980. Transportation operations on the Snake and Columbia Rivers 1979. Report to U.S. Army Corps of Engineers, Walla Walla District by NOAA, Natl. Mar. Fish. Serv., Seattle, 27 p. [avail. at https://www.nwfsc. noaa.gov/assets/26/7274_07112012_095854_ Smith.et.al.1980.pdf ]
}

the fish descaling rate was low and similar to 1978 , it was assumed that the low collection rate was a result of the large level of debris in the forebay of the dam (Williams and Matthews, 1995, discuss debris issues). Some of the debris impinged on the trash racks in front of turbines and presumably altered the flow of water which, in turn, decreased STS effectiveness (Park et al. $\left.{ }^{21}\right)$. At Little Goose Dam, the old orifice system had been dismantled, but a new system was not yet installed. Fish collected by dipnet from gatewells had much higher descaling levels than fish collected at Lower Granite Dam. At the end of the season, inspection of STS after removal from gatewells indicated that 9 of 18 screens had not functioned properly. Some screen panels were torn and others were in such poor condition they could not have operated as designed. The higher descaling rates at Little Goose Dam were presumably from the poor condition of screening material on the STS.

\section{Phase 3: Development and Evaluation of Screening Systems and Orifice Bypass Installations in Turbine Intakes at Lower Columbia River Dams, 1975-79}

Although STS guidance systems had been chosen for Lower Granite and Little Goose dams on the Snake River, problems still existed with maintenance and operation of the screens. Further, efforts to evaluate and maintain runs of Snake River salmon and steelhead stocks were almost exclusively targeted at yearling spring and summer Chinook salmon and steelhead, though some coho and sockeye salmon stocks still existed in the basin. The majority of juveniles of these stocks migrated through the lower Snake River from early April to early June. It was only initially envisioned that STS would have to operate during this period of time.

Similar to the Snake River, yearling Chinook, coho, and sockeye salmon and steelhead smolts that originated from the mid- and upper Columbia River areas migrated through the lower Columbia River in the spring; but additionally, a large number of subyearling summer and fall Chinook salmon smolts migrated from early June through September. Thus, while initial evaluations of STS in the Snake River found operational problems and it appeared that it would be possible to develop and maintain STS systems that could operate continuously for a couple of months in the spring, it didn't appear at first glance that it would be feasible to operate STS as configured for the 5-mo smolt-migration period in the Lower Columbia River. In addition, in 1974 NMFS proposed several studies as a first step of a research program to develop a more effective and less costly fingerling protection system for the Bonneville Dam Second Powerhouse scheduled for construction in the late 1970's, with completion due in the early 1980's.

Fish passage studies to develop a design for downstream facilities at the new Bonneville Dam Second Powerhouse began in 1975 with new measurements of vertical distribution of fish passing through turbines at Bonneville Dam First Powerhouse (Long ${ }^{23}$ ). These studies were conducted because it was not certain that earlier vertical distribution measurements of smolts passing turbine intakes at The Dalles and McNary dams (Long, 1968) represented what might occur at the new Bonneville Dam Second Powerhouse with turbine intakes having much less submergence. A net frame with a single row of fyke nets was placed in the operating gateslot while a cover blocked the bulkhead gateslot (Fig. 5). A greater percentage of fish of all species were found in the upper $29 \%$ of the turbine intake at Bonneville Dam compared to 1960 and 1961 vertical distribution studies at McNary and The Dalles dams. These results suggested that something other than pressure affected the vertical distribution of fish

\footnotetext{
${ }^{23}$ Long, C. W. 1976. Final report on vertical distribution of fingerling salmonids in turbine intakes of the Bonneville First Powerhouse. Report to U.S. Army Corps of Engineers, Portland District by NOAA, Natl. Mar. Fish. Serv., Seattle, 11 p. [avail. at https://www.nwfsc.noaa.gov/assets/26/7134_07022012_114543_Long.1976. pdf].
} 
in the intake because the opening to the operating gateslot at Bonneville Dam was much shallower at $11.2 \mathrm{~m}$ (depth below forebay surface) compared to the other two dams at approximately 19.7 m (Fig. 3).

In 1976, studies continued to begin to address two major goals needed for the Bonneville Second Powerhouse: 1) develop designs and operating criteria for submerged orifices that would efficiently pass fingerlings from gatewells into a safe bypass, and 2) develop less costly and more efficient methods to guide fish away from turbines compared to the STS systems currently undergoing testing at Lower Granite Dam (Long and $\mathrm{Krcma}^{24}$ ). With respect to orifices, earlier studies at Snake River dams had shown that the effectiveness of orifices was related to orifice size and location, VBS configuration, and the amount of flow into the gatewell. The size and angle of turbine intake screens affected gatewell flow.

Conditions tested in the Snake River often led to poor OPE with high levels of descaling on fish remaining in gatewells, sometimes even with fish that passed through the orifices successfully. To address this, new criteria for orifices were developed to assess if orifices worked adequately. It was decided that orifices should pass $90 \%$ of fish of all salmonid species that enter gatewells within $24 \mathrm{~h}$. The OPE was determined by comparing the number of fish collected in a trap on the downstream side of the orifice compared to the number of fish dipnetted from the gatewell at the end of a test, plus the total collected in the trap (Fig. 10).

The Bonneville First Powerhouse gatewells were darkened and lights placed at the downstream side of test orifices. With regard to actual orifice placement, another important criteria was that the hydraulic head required

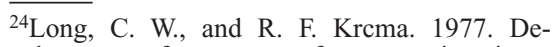
velopment of a system for protecting juvenile salmonids at the Second Powerhouse at Bonneville Dam - Progress 1976. Report to U.S. Army Corps of Engineers, Portland District by NOAA, Natl. Mar. Fish. Serv., Seattle, 15 p. [avail. at http://www.nwfsc.noaa.gov/assets/26/7136_07022012_115128_Long.and.Krcma.1977.pdf].
}

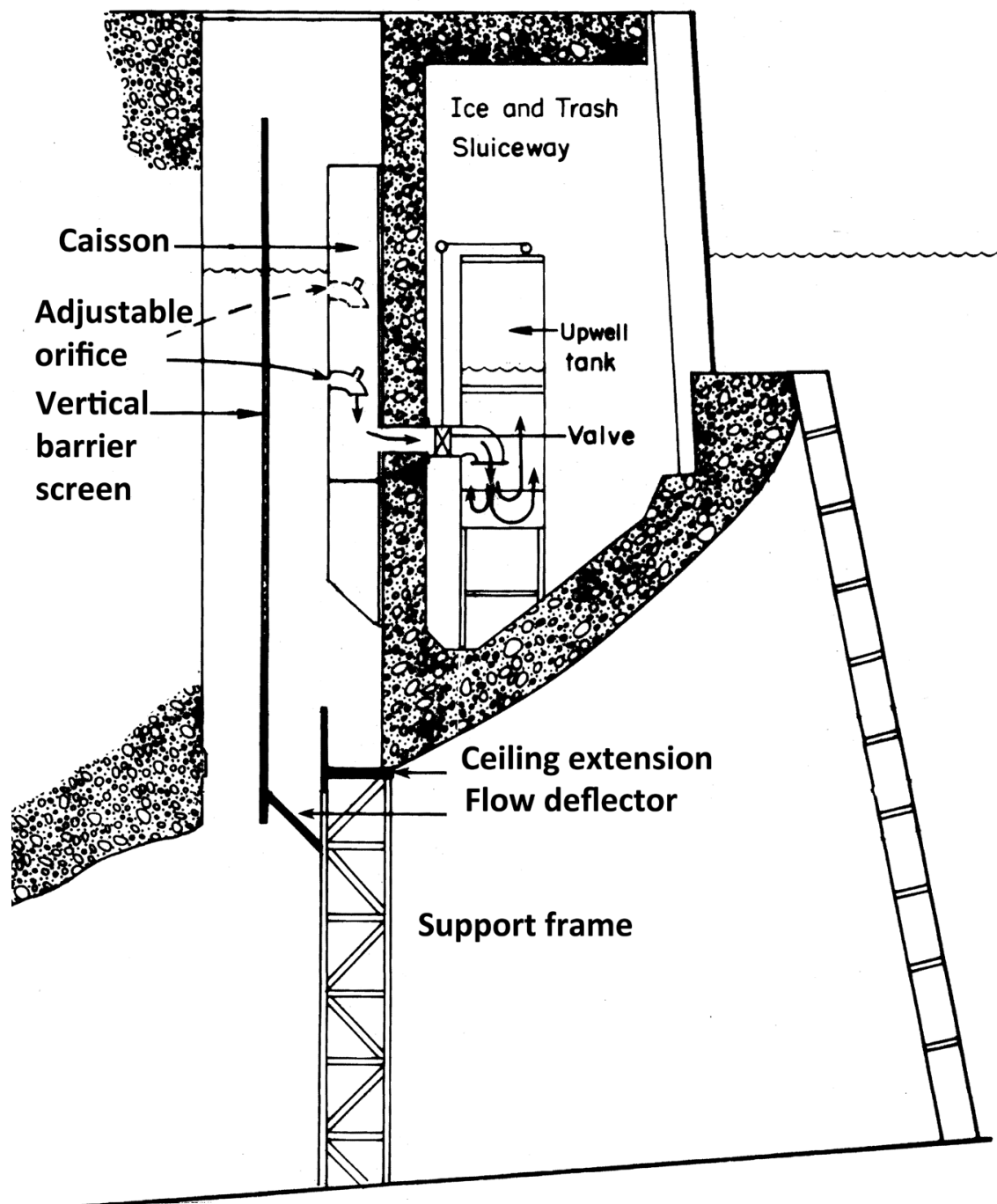

Figure 10.- Schematic configuration of orifice trap at Bonneville Dam First Powerhouse. A caisson was placed in one bulkhead gateslot to provide a configuration equivalent to what would occur within the bulkhead gateslot at the new Bonneville Dam Second Powerhouse. It also provided the ability to alter orifice head and placement. A flow deflector was installed to assure sufficient fish entered the gatewell for orifice testing. Ceiling extension added to also provide a configuration similar to the design of the bulkhead gateslot for the new Bonneville Dam Second Powerhouse.

to achieve adequate OPE should not exceed the submergence of the orifice because when the head must exceed submergence, construction of prototypes becomes much more difficult and costly. The test orifices were placed in a caisson at a distance from the VBS that would match the configuration in the new Bonneville Dam Second Powerhouse. Additionally, the VBS was blocked so that the open area was similar to what would exist at the Bonneville Dam Second Powerhouse. Orifices with diameters of 20.3, 25.4, 30.5 , and $45.7 \mathrm{~cm}$ diameter were tested with submergence from near the water surface to $2.4 \mathrm{~m}$.

Preliminary tests indicated that 20.3 $\mathrm{cm}$ diameter orifices could not meet the criteria, and the $45.7 \mathrm{~cm}$ diameter orifices far exceeded it. Efforts focused on testing variants of the 25.4 
and $30.5 \mathrm{~cm}$ diameter orifices. The $25.4 \mathrm{~cm}$ diameter orifices did not work well at submergences less than $\sim 1.2$ $\mathrm{m}$, while the $30.5 \mathrm{~cm}$ diameter orifices worked well with a submergence of as little as $\sim 0.75 \mathrm{~m}$. Testing was recommended for another year to determine if one or two $30.5 \mathrm{~cm}$ orifices were needed to meet the $90 \%$ passage criteria.

Also in 1976, studies began to evaluate the survival of fish that passed through the gatewell orifices into the ice and trash sluiceway, which emptied in the tailrace of McNary Dam (Sims and Johnsen ${ }^{25}$ ). This was needed because no detailed studies had determined the survival of fish entering the tailrace that had passed into the ice and trash sluiceway since the orifices were added in 1969. Test fish released at night into the north outfall at McNary Dam showed about a $50 \%$ increase in mortality over fish released into the north outfall during the day and over both day and night releases into the south outfall. The increased mortality may have related to increased predator activity generated by the availability of large numbers of fingerlings normally that exited the north outfall at night. Lighting on the deck may have also enhanced predator effectiveness in the area.

Finally, in 1976, the first studies were initiated at the NMFS Pasco Field Station to test alternatives to STS (Ruehle et al. ${ }^{26}$ ). An experimental oval flume was constructed with three pumps that provided the ability to create flows up to $2.4 \mathrm{~m} / \mathrm{sec}$. The flume was approximately $1 \mathrm{~m}$ wide, with a $48 \mathrm{~m}$ circumference and a water depth

\footnotetext{
${ }^{25}$ Sims, C. W., and R. C. Johnsen. 1977. Evaluation of the fingerling bypass system at John Day Dam and the fingerling bypass outfall at McNary Dam. Report to U.S. Army Corps of Engineers, Portland District by NOAA, Natl. Mar. Fish. Serv., Seattle, 16 p. [avail. at www.nwfsc.noaa. gov/assets/26/7258_07112012_084342_Sims. and.Johnsen.1977.pdf ].

${ }^{26}$ Ruehle, T. R., C. W. Long, and M. H. Gessel. 1978. Laboratory studies of a nontraveling bar screen for guiding juvenile salmonids out of turbine intakes. Report to U.S. Army Corps of Engineers, Walla Walla District by NOAA, Natl. Mar. Fish. Serv., Seattle, 14 p. [avail. at http://www.nwfsc.noa.gov/assets/26/6435_08122014_110849 Ruehle.et.al.1978.pdf ].
}

of about $2 \mathrm{~m}$. Tests were conducted on one of the $16 \mathrm{~m}$ long sides of the oval.

Two types of bar screens - a square bar and a triangular bar (Johnson wedge wire), with porosities of $33 \%$, $50 \%$, or $60 \%$-were tested under variable velocity conditions, at different angles to the flow, with variable configurations to a downstream vertical wall (simulating the opening to a bulkhead slot), and with differing amounts of debris. Fish without descaling were released upstream of the test configuration and observed through a clear Plexiglas window on the inside wall of the flume as they approached the screen, and they were subsequently collected to measure levels of descaling.

The researchers found no serious problems with a fixed screen causing descaling on fish. The optimum configuration that minimized fish descaling and accumulation of debris appeared to consist of a flat bar screen of $50 \%$ or greater porosity with a curved deflector at the terminal end. The screen angle to direction of flow should not exceed $20^{\circ}$ and the screen placement should position the terminal end above the downstream edge of the concrete wall that holds the VBS. The research results were sufficiently positive to justify field studies of a prototype bar screen in a turbine intake gatewell.

The first field study of bar screens in gatewells was conducted at Bonneville Dam First Powerhouse in 1977 (Krcma et al. ${ }^{27}$ ). The study utilized small bar screens (1.1 m long) (Fig. 11) with $0 \%, 35 \%$, or $65 \%$ porosity and fyke nets attached to a frame beneath the bar screen to collect unguided fish. The initial tests obtained FGE levels that ranged from $42 \%$ to $75 \%$ for all species. A bar screen with $0 \%$ open area guided significantly fewer fish than bar screens with $35 \%$ and $65 \%$ open area. Based on vertical dis-

\footnotetext{
${ }^{27}$ Krcma, R. F., C. W. Long, and C. S. Thompson. 1978. Research on the development of a fingerling protection system of low head dams-1977. Report to U.S. Army Corps of Engineers, Portland District by NOAA, Natl. Mar. Fish. Serv., Seattle, 32 p. [avail. at http://www.nwfsc.noaa. gov/assets/26/7109_06282012_123716_Krcma. et.al.1977.pdf]
}

tribution data from previous years, the 1977 FGE results suggested that nearly all the juvenile salmon that could be intercepted were in fact diverted into the gatewells. While the FGE levels were lower than found with STS at upriver dams, they were encouraging given the small size of the guiding device. Further, descaling levels and injury to guided fish were relatively low so that plans were made to continue studies at Bonneville Dam in 1978 as well as to construct a bar screen device that could be compared to the STS for testing at McNary Dam in 1978.

Orifice research at Bonneville Dam First Powerhouse in 1977 was directed at determining maximum efficiency and configuration of $30.5 \mathrm{~cm}$ diameter orifices. After many tests with one or two orifices, submergences between 0.9 and $3 \mathrm{~m}$, and with or without lights, it was found that between $75 \%$ and $89 \%$ OPE for all species was obtainable for orifices of 0.9 and $1.8 \mathrm{~m}$ submergence, respectively, in $24 \mathrm{~h}$ with one $30.5 \mathrm{~cm}$ diameter, backlit orifice with a darkened gatewell. Descaling rates of collected fish remained low even when large volumes of debris were experimentally placed in the gatewells with the fish. Based on these studies, it was decided that even though 90\% OPE was not obtained, since the quality of fish passing through the orifice and those that did not was high, $75 \%$ OPE in $24 \mathrm{~h}$ was a reasonable target.

Studies also continued in 1977 to determine potential outfall mortality at McNary and John Day Dams before the installation of screening systems (Sims and Johnsen ${ }^{28}$ ). Results suggested that the north outfall at McNary Dam did not lead to serious losses of fish, but that the outfall at John Day Dam was problematic because only a small number of fish exited to the tailrace (because no STS in turbine

\footnotetext{
${ }^{28} \mathrm{Sims}$, C. W., and R. C. Johnsen. 1978. Evaluation of the fingerling bypass system outfalls at McNary and John Day Dams. Report to U.S. Army Corps of Engineers, Portland District by NOAA, Natl. Mar. Fish. Serv., Seattle,13 p. [avail. at http://www.nwfsc.noaa.gov/assets/ 26/7259_07112012_084556_Sims.and.John sen.1978.p.pdf ]
} 


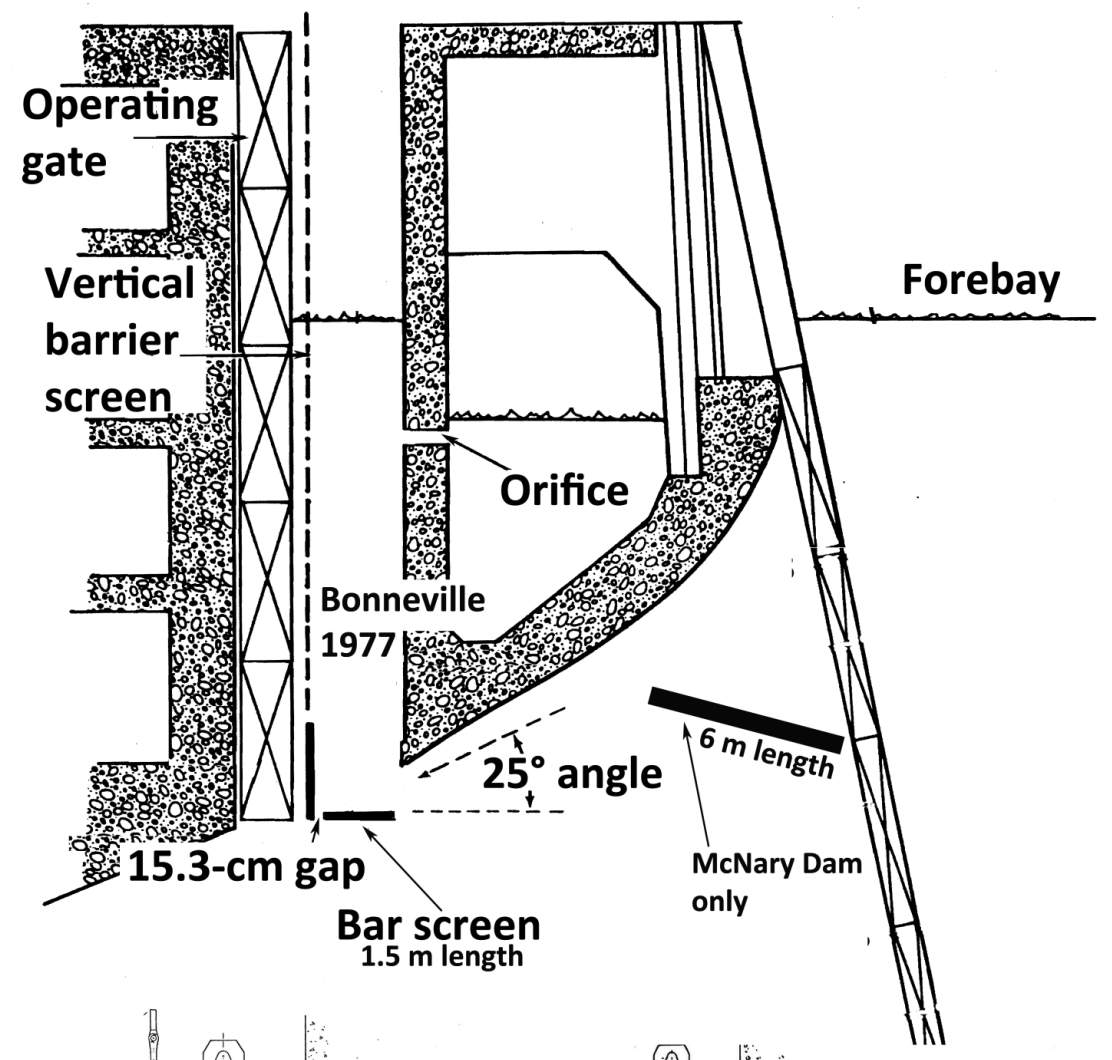

much lower FGE results. Researchers speculated that a longer bar screen that could intercept a greater percentage of the flow might provide significant increases in FGE, and they recommended that the USACE consider this for future studies.

Simultaneously to the Bonneville Dam studies, a two-part bar screen system was evaluated upriver at McNary Dam (Krcma et al. ${ }^{30}$ ). A bar screen similar to the one used at Bonneville Dam was inserted into the bulkhead gateslot and a deflecting screen was attached to the trash rack of the turbine intake (Fig. 11). The two-part guiding system was designed to intercept approximately the same amount of flow as STS. During FGE tests, the hydraulic gate in the operating gateslot was raised to increase the flow above the horizontal bar screen and into the bulkhead gateslot.

The support frame for the bar screen deflector also had fyke nets attached, which allowed the ability to measure FGE for each test condition. Additionally, a gap net was positioned at the downstream end of the bar screen to capture fish and/or debris that was intercepted but not diverted into the gatewell. Results of the bar screen tests found that FGE was higher during the day than during the night, but because tests were mostly conducted over a period that included day and night conditions, most data were a combination of overall guidance. A comparison was made between the 2-part bar screen FGE results and what was considered theoretically obtainable based on the vertical distribution data gathered in 1961. The 2-part system tended to guide considerably fewer sockeye and Chinook salmon than expected, but steelhead were guided at about the theoretical maximum. It was not easy

intakes and no VBS in gatewells), and they had high levels of mortality.

In 1978, three different bar screen configurations were tested at Bonneville Dam First Powerhouse, but none of the results were as good as those found in 1977, and all FGE results were considered inadequate (Krcma et al. $\left.^{29}\right)$. Further, no apparent causes were identified that could explain the

${ }^{29} \mathrm{Krcma}$, R. F., C. W. Long, C. S. Thompson, W. E. Farr, T. W. Newcomb, and M. H. Gessel. 1979. The development of an improved fingerling protection system for low head dams, 1978. Report to U.S. Army Corps of Engineers, Portland District by NOAA, Natl. Mar. Fish. Serv., Seattle, 40 p. [avail. at http://www.nwfsc.noaa.
gov/assets/26/6684_10152010_142909_Krcma. et.al.1979b-rev.pdf ].

${ }^{30}$ Krcma, R. F., W. E. Farr, and C. W. Long. 1980. Research to develop passive bar screes for guiding juvenile salmonids out of turbine intakes at low head dams on the Columbia and Snake Rivers, 1977-1979. Report to U.S. Army Corps of Engineers, Portland District by NOAA, Natl. Mar. Fish. Serv., Seattle, 28 p. [avail. at https://www.nwfsc. noaa.gov/assets/26/8975_11302016_111431_ Krcma.et.al.1980-SBS.pdf ] 
to get a perfect comparison to guidance with an STS. A very incomplete bypass system existed and only four turbines had VBS. However, some very cursory tests in turbine intake slot 4B with an STS indicated that across all species, overall FGE was approximately $68 \%$ compared to only $25 \%$ on similar days for the bar screen, and $7 \%$ in turbine intake 7B with no screens at all. The bar screen deflector increased descaling minimally, $1-1.5 \%$, when compared to fish removed from gatewells with no guidance device.

Based on the OPE results at Bonneville Dam in 1976-77, the two 15.2 $\mathrm{cm}$ diameter orifices in each turbine intake gatewell at McNary Dam were bored to a $30.5 \mathrm{~cm}$ diameter size. In 1978 , tests of one or two $20.3 \mathrm{~cm}$ diameter orifices (inserts placed into the $30.5 \mathrm{~cm}$ diameter orifices) were compared against one $30.5 \mathrm{~cm}$ diameter orifice. After testing, researchers recommended using one $30.5 \mathrm{~cm}$ diameter orifice in each gatewell because less debris could clog an orifice and overall guidance between the two smaller orifices and the larger orifice were similar.

For the 1979 testing season at McNary Dam, the USACE redesigned the gatewell deflector to increase the length to $4.9 \mathrm{~m}$ from the previous year's $2.5 \mathrm{~m}$, while the trash rack deflector remained the length used in 1978 (Fig. 11.) For tests, one bar screen and one trash rack deflector was installed in all three intakes of the test turbine. Tests evaluated three different screen porosities created by using different panels of wedge wire with different inter-spaces (Krcma et al. ${ }^{30}$ ).

Efficacy of different bar screen combinations was evaluated by comparing FGE of the bar screen results to FGE results with STS, levels of descaling, and swimming performance of a sample of fish removed from the gatewell. Descaling and swimming performance of fish volitionally entering adjacent gatewells without a guidance device were used as controls. The 2-part bar screen guidance system performed nearly the same as STS for most salmonid smolts, with the exception of sockeye and juvenile Chinook salmon $<70 \mathrm{~mm}$ in length. The guidance for bar screens of $52 \%$ and $62 \%$ porosity was consistently higher than the $35 \%$ porosity. However, bar screens with an interspace of $3.2 \mathrm{~mm}$ impinged excessive numbers of juvenile lamprey, Lampetra spp., and subyearling Chinook salmon of $<70 \mathrm{~mm}$ fork length if the angle-to-flow exceeded $45^{\circ}$. The percentage of descaled fish (all species) was low for both the bar screen and STS, and fish guided into gatewells by screens had similar descaling to fish recovered from gatewells without screening devices. Likewise, swimming stamina tests for all groups had similar results.

The conclusion drawn from the $3 \mathrm{yr}$ of bar screen studies were that passive bar screens provided a potentially viable method for guiding juvenile salmonids from turbine intakes, although their use was more limited than STS. Caveats for the bar screen were that they would potentially not work well if the vertical distribution of fish in the turbine intakes was too low, fish were too small, or ambient water velocities in turbine intakes were too high. Further, development of some method to remove accumulated debris from the screens was required, other than the costly method used in the test studies to back-flush the screens.

\section{Assessment of Bypass Development to Date, 1980}

In the Snake River, with the exception of the indirect estimate of low FGE at Lower Granite Dam in 1979a value attributed to debris on trash racks - it appeared the STS could guide more than $70 \%$ of migrants entering turbine intakes into gatewells. Descaling of fish in gatewells was attributed to problems with damaged mesh on STS and undersized orifices. Orifice sizes were increased at Lower Granite and Little Goose dams.

Somewhat discouragingly, however, as part of a 1980 study to estimate survival of juveniles passing dams on the lower Snake and Columbia Rivers, it was determined through deductive models that the estimated percent- age of the smolt run arriving at Lower Granite Dam that was collected by the STS/orifice systems was approximately $36 \%$ and $51 \%$ for Chinook salmon and steelhead smolts, respectively (Sims et al. ${ }^{31}$ ); levels that were considerably lower than the target of $70 \%$. Furthermore, these estimates were similar to those of 1979 , even though most of the debris that existed in 1979 had been removed. Thus, it didn't appear that debris on the trash rack in 1979 was the cause for the estimated low guidance. However, the results of the 1980 studies were not finalized until the winter of 1980-81, which was too late to plan for additional studies at Snake River dams in spring 1981.

Some of the lower guidance by screens was attributed to an incorrect construction of the upper framework on the new variable-angle STS such that the throat opening to the bulkhead gateslot was restricted (Fig. 12). While not affecting steelhead FGE to the same extent, it may have caused hydraulic conditions that impeded the collection of Chinook salmon. On a positive note, descaling rates of Chinook salmon smolts in gatewells at Lower Granite Dam were consistently low throughout the year. Steelhead descaling rates were somewhat higher, but it appeared much of it occurred upstream of the dam.

Nonetheless, the debris at lower Granite Dam did continuously cause issues with partial plugging of orifices. To alleviate this required close monitoring of orifices and frequently closing each orifice, back flushing to remove debris, and then reopening to obtain unobstructed flow. At Little Goose Dam, however, the newly installed $30.5 \mathrm{~cm}$ diameter orifices worked so well that in 1980 it was difficult to dipnet enough fish from

\footnotetext{
${ }^{31}$ Sims, C. W., J. G. Williams, D. A. Faurot, R. C. Johnsen, and D. A. Brege. 1981. Migrational characteristics of juvenile salmon and steelhead in the Columbia River Basin and related passage research at John Day Dam, Volumes I \& II. Report to U.S. Army Corps of Engineers, Portland District by NOAA, Natl. Mar. Fish. Serv., Seattle, 360 p. [avail. at https://www.nwfsc.noaa. gov/assets/26/7268_07112012_091428_Sims. et.al.1981.pdf ].
} 


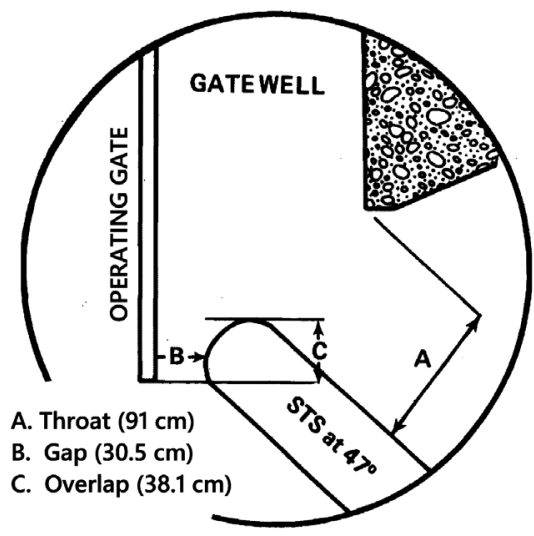

Figure 12.- Schematic showing the three critical dimensions of the upper part of a turbine intake screen lowered into the 'standard' position within the bulkhead slot at Bonneville Dam First Powerhouse. The three critical dimensions varied among dams as different dams had different ceiling intake and bulkhead slot configurations. When measured, guidance was lower than expected, often during the field research the screens were lowered to increase the throat area. This often then required putting in false ceilings to limit the gap opening or assure sufficient overlap existed to prevent fish passing over the screen, out through the gap, and into the turbine.

gatewells to get good measurements of descaling caused by STS (Smith et al. ${ }^{32}$ ).

Decisions were necessary on how to proceed with bypass system installation at dams. After $3 \mathrm{yr}$ of testing bar screen devices at Bonneville and McNary Dams, it was determined that more design and testing of bar screens would need to occur before it was possible to consider implementing them $\left(\mathrm{Krcma}\right.$ et al. $\left.{ }^{29}\right)$. This was not considered a near-term viable option. Thus, efforts were focused on the use of STS. Understanding the estimated poor FGE at Lower Granite Dam in 1980 was critical. A closer review of previous FGE

\footnotetext{
${ }^{32}$ Smith, J. R., G. M. Matthews, L. R. Basham, B. H. Monk, and S. Achord. 1981. Transportation operations on the Snake and Columbia River, 1980. Report to U.S. Army Corps of Engineers, Walla Walla District by NOAA, Natl. Mar. Fish. Serv., Seattle, 31 p. [avail. at https://www.nwfsc. noaa.gov/assets/26/7273_07112012_094308_ Smith.et.al.1981.pdf ].
}

results with a comparison to 1980 estimates suggested that most evaluations of potential STS effectiveness were potentially biased high.

The bias may have resulted from hose releases that did not adequately represent the natural migrant population, or differences in absolute recaptures of migrants (either marked or unmarked) migrating downstream and subsequently removed from gatewells with and without STS didn't represent the entire population entering a turbine intake. These concerns had always existed, but concerns about fish losses from using fyke nets took precedence. The review confirmed that more rigorous testing at Snake River dams was needed. On the other hand, the limited FGE research at McNary Dam with STS and fyke-net frames under the STS suggested that $70 \%$ or greater FGE for yearling salmonid migrants, with the exception of sockeye salmon, was obtainable with a STS. Because the Columbia River Fisheries Council had determined that developing a workable juvenile bypass system at John Day was a high priority, the USACE decided to move forward with development and installation of STS at dams in not only the Snake River, but also in the lower Columbia River, in addition to finishing installation of STS in all turbine intake gatewells at McNary Dam.

From a research standpoint, the review of data made it clear that despite increased mortality of migrants that would occur, to attain the information needed to make decisions on the effectiveness of STS would require more complete evaluations that compared numbers of fish that entered gatewells in turbine intakes with a guidance device to estimated numbers of fish that passed under the guidance device and were lethally captured in fyke nets attached below the device. This recommendation was presented to USACE and federal, state, and tribal fishery agencies. It was reluctantly accepted as necessary but with concern about fish losses due to sampling. Agreements were made to minimize fyke netting under STS to the extent pos- sible while still providing the information on FGE needed for management decisions.

Clearly, developing effective systems to divert fish from passing through turbines also required that the systems would minimize adverse effects on fish. Descaling of fish was a particular problem identified in some cases. It could occur from fish interactions directly with a screening device or after fish were diverted into gatewells and as a result of interactions with the VBS caused by turbulence. Turbulence varied with the screening types and the amount of flow going into the bulkhead slot. Finally, while the initial installation of $15.2 \mathrm{~cm}$ diameter orifices were based on some early work at Ice Harbor Dam suggesting that they would work sufficiently well, it soon became clear on evaluation of orifices at other dams that they did not. Smaller orifices did not pass fish out of gatewells nearly as effectively as larger diameter orifices. Further, the longer fish stayed in gatewells, the more interaction they had with debris and VBS; thus, leading to higher descaling rates. This led to concern about the overall time fish spent in gatewells. As a consequence, the basis for an effective orifice system was changed from not only having low descaling rates for fish within gatewells, but also that $75 \%$ or greater of fish entering a gatewell must pass through the installed orifices within 24 h (Ruehle et al. ${ }^{26}$ ).

\section{Phase 4: STS Evaluations and Orifice Research at Lower Columbia River Dams, 1981-85}

\section{McNary Dam}

In 1981, studies to develop a bypass system for John Day Dam commenced at McNary Dam and were conducted there for economic and practical reasons (Swan et $\mathrm{al}^{33}$ ). Much of the

${ }^{33}$ Swan, G. A., R. F. Krcma, and C. W. Long. 1982. Research to develop an improved fingerling protection system for John Day Dam, 1981. Report to U.S. Army Corps of Engineers, Portland District by NOAA, Natl. Mar. Fish. Serv., Seattle, 22 p. [avail. at http://www.nwfsc.noaa. 
needed equipment was already on site at McNary Dam, and it was possible to raise the operating gates at McNary Dam to simulate flow conditions into the gatewell that would occur at John Day Dam. While not exactly the same, the configuration of the two dams was at the time considered similar enough that results at McNary Dam would apply to John Day Dam

The average FGE (John Day condition with no operating gate) for yearling Chinook salmon and steelhead was $75 \%$ and $79 \%$, respectively, based on a series of tests with fyke nets mounted below the STS. Test orifices were located at submergences of 2.4 and $5.2 \mathrm{~m}$, with the deeper orifice simulating a John Day Dam configuration, the shallower one for McNary Dam. The OPE was unacceptable. In general, OPE was better for the McNary condition than for the John Day condition, but OPE only exceeded $75 \%$ for steelhead. Turbulence in the gatewell caused by increased water flow due to the lack of a stored operating gate was considered the probable reason for the low OPE.

Because of the poor OPE in 1981, in 1982 studies at McNary Dam to develop information for John Day Dam were focused on determining the information needed for orifice placement and operation (Krcma et al. ${ }^{34}$ ). Secondarily, FGE studies were conducted for a John Day condition (raised operating gate) and a McNary condition (stored operating gate) to evaluate subyearling Chinook guidance because the preliminary 1979 research at McNary Dam with the new variableangled STS indicated potentially unacceptable FGE for subyearling Chinook salmon migrating in the summer.

As part of the conditions tested, a new VBS designed by the USACE

gov/assets/26/7300 07162012091349 Swan. et.al.1982.pdf ].

${ }^{34} \mathrm{Krcma}$, R. F., M. H. Gessel, and F. J. Ossiander. 1983. Research at McNary Dam to develop and implement a fingerling protection system for John Day Dam. Report to U.S. Army Corps of Engineers, Portland District by NOAA, Natl. Mar. Fish. Serv., Seattle, 24 p. [avail. at http://www.nwfsc. noaa.gov/assets/26/7111_07022012_092423_ Krcma.et.al.1983.pdf ]. was installed into gatewells of the two turbines used for FGE tests. The new design created an overall VBS porosity of $15 \%$, attained by the addition of a perforated plate on the screen to balance the velocity of water through the screen to a uniform $15 \mathrm{~cm} / \mathrm{s}$. The polyester mesh screen had a spacing of 2.4 vertical and 2.4 horizontal, $1 \mathrm{~mm}$ strands per $\mathrm{cm}^{2}$. The screen was designated a balanced-flow vertical barrier screen (BFVBS). Compared to a standard VBS, it improved flow into and decreased the turbulence within the gatewell. It was hoped that the new BFVBS would improve conditions within the gatewell that would lead to higher OPE. The OPE tests included a range of submergences from 1.8 to 6.1 $\mathrm{m}$ and head over the orifice between 1.2 and $2.1 \mathrm{~m}$.

The OPE levels for gatewells equipped with BFVBS were generally acceptable throughout the range of orifice submergences and heads tested, provided the test duration was greater than $24 \mathrm{~h}$ and the orifices were backlighted. The OPE tests of $48 \mathrm{~h}$ duration did not cause a significant increase in descaling. Because flow conditions varied between gatewells and turbines, additional studies were recommended before determining where to place orifices (south or north side of gatewells). Sufficient data were collected to recommend installation of a single 30.5 $\mathrm{cm}$ diameter orifice at a depth of $4.8 \mathrm{~m}$ below full pool (summer conditions) which would provide a submergence of $2.1 \mathrm{~m}$ at the minimum pool level which often occurs during the spring migration. Gatewells should also have BFVBS.

The mean FGE for subyearling Chinook salmon was approximately 50\%, a value significantly lower than that measured on yearling Chinook salmon and steelhead $(75 \%$ and $85 \%$, respectively). Because there was high variability in results and debris buildup on barrier screens during subyearling Chinook salmon migrations, additional testing was recommended to attain more precise FGE estimates for subyearling Chinook salmon and its relationship to levels of debris on BFVBS, fish size, and fish condition. In addition, it was recommended that a provision for routine cleaning of BFVBS was needed to assure that debris obstruction did not negate the flow through the screens.

Finally, in 1982, intermittent operation of STS was tested to determine if it were possible to decrease wear on STS without impacting guided smolts (McCabe and $\mathrm{Krcma}^{35}$ ). Intermittent operation of STS did not increase impingement rates for yearling Chinook salmon and steelhead or descaling rates when compared to full-time operation. Approximately $1.3 \%$ of subyearling Chinook salmon was impinged on the STS during the non-operating phase. Even with this low mortality percentage, because millions of fall Chinook salmon enter the turbine intakes, it was deemed an unacceptable number of mortalities. It was concluded that during the early spring when juvenile steelhead trout and yearling Chinook salmon migrate, STS could be operated intermittently as tested because the large fish were not impinged.

The poor FGE results in 1982 for subyearling Chinook salmon led to more directed investigations between 18 July and 9 August during the 1984 summer outmigration (Krcma et al. ${ }^{36}$ ). Research results indicated that theoretical FGE varied considerably, but progressively decreased from a high of $77 \%$ in mid-July to a low of $56 \%$ in early August. Concurrently FGE for subyearling Chinook salmon was variable and unacceptably low for all tests. In the first three sets of tests, FGE was measured with a BFVBS, and in the last set with a VBS.

\footnotetext{
${ }^{35} \mathrm{McCabe}, \mathrm{G}$. T., and R. F. Krcma. 1983. Effects of intermittent operation of submersible traveling screens on juvenile, salmonids, 1982. Report to U.S. Army Corps of Engineers, Walla Walla District by NOAA, Natl. Mar. Fish. Serv., Seattle, 29 p. [avail. at http://www.nwfsc.noaa.gov/ assets/26/7173_07042012_101215_McCabe. and.Krcma.1983.pdf ].

${ }^{36}$ Krcma, R. F., G. A. Swan, and F. J. Ossiander. 1985. Fish guiding and orifice passage efficiency tests with subyearling Chinook salmon, McNary Dam, 1984. Report to U.S. Army Corps of Engineers, Walla Walla District by NOAA, Natl. Mar. Fish. Serv., Seattle, 29 p. [avail. at http://www.nwfsc.noaa.gov/assets/26/6685_10152010_150739_ Krcma.et.al.1984b-rev.pdf].
} 
In the first two sets of tests in midJuly, FGE averaged $34 \%$ and $39 \%$; they were conducted post-dusk. In the third set of tests in late July conducted pre-dusk, FGE averaged $46 \%$. The last set of tests from 7 to $9 \mathrm{Au}-$ gust was also conducted pre-dusk, but FGE only averaged $33 \%$. It appeared that the BFVBS increased the potential FGE, but no clear indications existed to explain the overall low FGE for subyearling migrants other than they passed into the turbine intakes at a lower level than yearling migrants in the spring. The BFVBS had been slightly modified by removing part of the solid panel at the top to provide more flow toward the orifice. This resulted in successful OPE tests. With the modified BFVBS, OPE averaged more than $75 \%$ within $24 \mathrm{~h}$ for all sets of tests.

\section{John Day Dam}

Based on research results from McNary Dam, the John Day Dam juvenile salmonid collection and passage system was rehabilitated and evaluations of it began in 1985 ( $\mathrm{Krcma}$ et al. ${ }^{37}$ ). The $54^{\circ}$ angled STS produced FGE of $72 \%, 41 \%$, and $86 \%$ for yearling Chinook salmon, sockeye salmon, and steelhead, respectively, while not causing excessive descaling. The FGE for subyearling Chinook salmon was a disturbingly low $21 \%$. When the FGE of subyearling Chinook salmon was compared to the percentage of fish captured in the vertical distribution fyke nets, only about $40 \%$ of the fish considered guidable were, in fact, guided. The comparison of FGE to the percentage of fish considered guidable was termed theoretical FGE (TFGE). The TFGE value and absolute FGE values were lower than expected based on results of testing the John Day conditions tested at McNary Dam in 1982.

\footnotetext{
${ }^{37} \mathrm{Krcma}$, R. F., D. A. Brege, and R. D. Ledgerwood. 1986. Evaluation of the rehabilitated juvenile salmonid collection and passage system at John Day Dam - 1985. Report to U.S. Army Corps of Engineers, Portland District by NOAA, Natl. Mar. Fish. Serv., Seattle, 25 p. [avail. at https://www.nwfsc.noaa.gov/ assets/26/6686_10152010_151929_Krcma. et.al.1986-rev.pdf ] .
}

Direct estimates of OPE were only obtained for yearling Chinook salmon and steelhead and they were $71.7 \% \pm$ $25 \%$ and $53.2 \% \pm 14.9 \%$, respectively. Indirect OPE estimates for yearling Chinook salmon (76.8\%) and sockeye salmon (78.4\%) exceeded the goal of $75 \%$, but subyearling Chinook salmon $(71.3 \%)$ and steelhead $(66.5 \%)$ were slightly below the goal. The tests in 1985 were conducted on a partially completed bypass system that led to a head on the orifices during OPE tests that was nearly double $(2.2 \mathrm{~m})$ the head that would exist on a completed bypass system.

Thus, OPE tests were repeated in 1986, however, results were similar to those obtained in 1985 (Brege et al. ${ }^{38}$ ). Additionally, since the FGE tests for subyearling Chinook salmon were only conducted over a 3-day period in 1985, in 1986 repeat evaluations of FGE over a longer period during the summer were also conducted with an overall average FGE of $35 \%$. The results were higher than in 1985 but still far below target values.

\section{Bonneville Dam First Powerhouse}

Although the decision had been made to move forward with STS at all dams, in 1981 at the Bonneville First Powerhouse one last effort to evaluate the feasibility of a possible alternative to STS was considered: To open gates on the ice and trash sluiceway to create a surface flow into the sluiceway that would attract fish into it as they approached the powerhouse rather than milling around in surface waters during daylight conditions before passing downward into the turbine intakes in the evening hours.

At Bonneville Dam First Powerhouse, adjustable-angle STS initially tested at McNary Dam in 1979 were evaluated in Turbine Unit 4 against

\footnotetext{
${ }^{38}$ Brege, D. A., D. R. Miller, and R. D. Ledgerwood. 1987. Evaluation of the rehabilitated juvenile salmonid collection and passage system at John Day Dam - 1986. Report to U.S. Army Corps of Engineers, Portland District by NOAA, Natl. Mar. Fish. Serv., Seattle, 37 p. [avail. at https://www.nwfsc.noaa.gov/ assets/26/8852_09142016_180754_Brege. et.al.1997.pdf ].
}

fish passing into the ice and trash sluiceway ( $\mathrm{Krcma}$ et al. ${ }^{39}$ ). The STS could be positioned at three elevations within the turbine intake in $\mathbf{1 5 . 2}$ $\mathrm{cm}$ increments, and the screen surface set to four different angles $\left(47^{\circ}, 53^{\circ}\right.$, $60^{\circ}$, and $65^{\circ}$ measured up from vertical). These two adjustments allowed considerable flexibility to change the throat opening, gap opening, overlap, and the percent of the total turbine intake flow intercepted by the STS in the operating position (Fig. 12).

As noted above, it was tested with a full array of fyke nets on a frame below the screen in order to provide good estimates of fish not guided into gatewells compared to those captured from the gatewell. Finally, TFGE was estimated based on recovery of fish from vertical distribution fyke nets. Research was also conducted to determine if it was possible to cycle orifices off and on ( $2 \mathrm{~h}$ and $1 \mathrm{~h}$ or $4 \mathrm{~h}$ and $2 \mathrm{~h}$ ) and obtain acceptable OPE compared to orifices operated continuously, with the intent to determine if the amount of debris and orifice clogging would decrease with less orifice operation.

Initially, all three STS's were set at the lowest elevation (13.3 m mean sea level) and at the smallest angle $\left(47^{\circ}\right)$. The standard test configuration had the three STS's in turbine Unit 4, with the bar screen device in an adjacent gatewell (either $3 \mathrm{C}$ or $5 \mathrm{~A}$ ). During the period 30 April-6 June, a total of 36 guidance tests were conducted. The results of these tests found FGE in excess of $70 \%$ for nearly all species when the STS was set at a $47^{\circ}$ angle and operated at the $13.3 \mathrm{~m}$ elevation.

The FGE was lowest for subyearling Chinook salmon $(71.5 \%)$ due primarily to loss through the gap (8.7\%) at the top of the screen. The quality of STS guided fish was acceptable, with only

\footnotetext{
${ }^{39}$ Krcma, R. F., D. DeHart, M. H. Gessel, C. W. Long, and C. W. Sims. 1982. Evaluation of submersible traveling screens, passage of juvenile salmonids through the ice-trash sluiceway, and cycling of gatewell-orifice operations at Bonneville First Powerhouse, 1981. Report to U.S. Army Corps of Engineers, Portland District by NOAA, Natl. Mar. Fish. Serv., Seattle, 25 p. [avail. at http://www.nwfsc.noaa.gov/ assets/26/7110_07022012_092050_Krcma. et.al.1982.pdf ].
} 
minor differences noted in descaling rates between test and control fish. Vertical distribution measurements of fish indicated TFGE ranged from $75 \%$ to $90 \%$.

Subyearling Chinook and sockeye salmon were generally more deeply distributed than steelhead. The FGE was generally 2-times greater compared to fish passing through sluicegates into the ice and trash sluiceway. Because it appeared that the adjustable-angle STS was a workable option, no additional research was scheduled for the next year, and the process of developing designs for installation of STS in all the turbines at Bonneville Dam First Powerhouse was started.

Unfortunately, OPE was less than $30 \%$ after $24 \mathrm{~h}$ of operation for all test and control conditions. After $72 \mathrm{~h}$ of operation, orifices that were operated continuously attained OPE levels of $85 \%$; however, OPE of cycled orifices changed little from values seen after $24 \mathrm{~h}$ of operation. None of the orifice results met the OPE target of $75 \%$ of fish leaving a gatewell within $24 \mathrm{~h}$ of entering, nonetheless, as part of the STS installation, $30.5 \mathrm{~cm}$ diameter orifices were drilled into all gatewells.

In 1984, OPE studies were again conducted. Because of debris loads in gatewells and concerns about potential plugging of orifices, comparisons were made between $30.5 \mathrm{~cm}$ diameter and $35.6 \mathrm{~cm}$ diameter orifices (Gessel et al. $\left.{ }^{40}\right)$. Target species were yearling and subyearling Chinook salmon. Tests were conducted in May, when yearling fish dominated the catch, and in June and July, when mostly subyearling chinook salmon were present. For yearling Chinook salmon, average OPE estimates were $70 \%$ for the $35.6 \mathrm{~cm}$ diameter orifice and $73 \%$ for the 30.5 $\mathrm{cm}$ diameter orifice, but there was no significant difference between the two.

\footnotetext{
${ }^{40}$ Gessel, M. H., R. F. Krcma, W. D. Muir, C. S. McCutcheon, L. G. Gilbreath, and B. H. Monk. 1985. Evaluation of the juvenile collection and bypass systems at Bonneville Dam - 1984. Report to U.S. Army Corps of Engineers, Portland District by NOAA, Natl. Mar. Fish. Serv., Seattle, 76 p. [avail. at https://www.nwfsc.noaa. gov/assets/26/6996_05212012_082052_Gessel. et.al.1985a.pdf ]
}

In the summer, the average OPE for subyearling Chinook salmon was $85 \%$.

In 1985, studies were repeated to determine if OPE differences existed between gatewells with VBS or BFVBS, and, to decrease variability of the results, only the $35.6 \mathrm{~cm}$ diameter orifices tested in 1984 were used (Gessel et al. $\left.{ }^{41}\right)$. The OPE did not vary based on VBS type and was higher than observed in 1984. For yearling Chinook salmon, OPE ranged from $82 \%$ to $93 \%$ and it exceeded $90 \%$ for all other yearling migrants. For subyearling Chinook salmon, OPE varied throughout the summer, ranging from $85 \%$ in early summer to $39 \%$ in late summer, with a weighted average of $64 \%$.

The most important finding was that orifices did not successfully pass fish from gatewells if the head over them was less than $75 \mathrm{~cm}$-a height that produced a velocity of water through the orifices of approximately $3.75 \mathrm{~m} / \mathrm{s}$. This was determined when an early morning inspection of the gatewells found that all of them contained 2,000-5,000 smolts. For power production purposes, water used from the reservoir had dropped the forebay level by approximately $60 \mathrm{~cm}$. This was within the normal operating range of the forebay, but it was outside what could occur with the new fish bypass system installed at Bonneville Dam. As a consequence, the operating rules for the forebay were changed to require the reservoir to stay within 30 $\mathrm{cm}$ of full pool during periods when downstream fish passage occurred. Orifice sizes at Bonneville Dam First Powerhouse were increased to $35.6 \mathrm{~cm}$ diameter.

\section{Bonneville Dam Second Powerhouse}

In 1982, the smolt collection system at Bonneville Dam Second Powerhouse was completed, and an evaluation of the system began in 1983

\footnotetext{
${ }^{41}$ Gessel, M. H., L. G. Gilbreath, W. D. Muir, and R. F. Krcma. 1986. Evaluation of the juvenile collection and bypass systems at Bonneville Dam 1985. Report to U.S. Army Corps of Engineers, Portland District by NOAA, Natl. Mar. Fish. Serv., Seattle, 103 p. [avail. at https://www.nwfsc.noaa.gov/assets/26/6998_05212012_083107_ Gessel.et.al.1986.pdf].
}

(Krcma et al. ${ }^{42}$ ). Guiding efficiency of the STS was disturbingly low for all species and all conditions tested. Research to assess changes to the STS, dam, and dam operations occurred over the next $6 \mathrm{yr}$ in an attempt to improve FGE (Gessel et al. ${ }^{40,} 41,43,44,45$, $\left.{ }^{46}\right)$. A summary of these efforts was previously published by Gessel et al. (1991).

Additionally, in 1983 initial research was conducted to determine OPE for the new system (Krcma et al. ${ }^{39}$ ). A series of four tests was conducted between 26 April and 3 May. The OPE was $66 \%$ for steelhead, $66 \%$ for yearling Chinook salmon, 64\% for coho salmon, 59\% for sockeye salmon, and $85 \%$ for subyearling Chinook salmon. Additional OPE testing was delayed until a more acceptable FGE was achieved.

\footnotetext{
${ }^{42}$ Krcma, R. F., M. H. Gessel, W. D. Muir, C. S. McCutcheon, L. G. Gilbreath, and B. H. Monk. 1984. Evaluation of the juvenile collection and bypass system at Bonneville Dam -- 1983. Report to U.S. Army Corps of Engineers, Portland District by NOAA, Natl. Mar. Fish. Serv., Seattle, 68 p. [avail. at http://www.nwfsc.noaa. gov/assets/26/7112_07022012_092841_Krcma. et.al.1984a.pdf].

${ }^{43}$ Gessel, M. H., L. G. Gilbreath, W. D. Muir, B. H. Monk, and R. F. Krcma. 1987. Evaluation of the juvenile collection and bypass systems at Bonnevillle Dam - 1986. Report to U.S. Army Corps of Engineers, Portland District by NOAA, Natl. Mar. Fish. Serv., Seattle, 54 p. [avail. at https://www.nwfsc.noaa.gov/ assets/26/7000_05212012_085026_Gessel. et.al.1987b.pdf ].

${ }^{44}$ Gessel, M. H., B. H. Monk, and J. G. Williams. 1987. Continuing studies to improve and evaluate the fingerling collection and bypass systems at Bonneville Dam. Report to U.S. Army Corps of Engineers, Portland District by NOAA, Natl. Mar. Fish. Serv., Seattle, 17 p. [avail. at https://www.nwfsc.noaa.gov/ assets/26/6999 05212012083425 Gessel. et.al.1987a.pdf ].

${ }^{45}$ Gessel, M. H., B. H. Monk, D. A. Brege, and J. G. Williams. 1989. Fish guidance efficiency studies at Bonneville Dam First and Second powerhouses - 1988. Report to U.S. Army Corps of Engineers, Portland District by NOAA, Natl. Mar. Fish. Serv., Seattle, 36 p. [avail. at https://www.nwfsc. noaa.gov/assets/26/7002 05212012085721 Gessel.et.al.1989a.pdf ].

${ }^{46}$ Gessel, M. H., D. A. Brege, B. H. Monk, and J. G. Williams. 1990. Continued studies to evaluate the juvenile bypass systems at Bonneville Dam 1989. Report to U.S. Army Corps of Engineers, Portland District by NOAA, Natl. Mar. Fish. Serv., Seattle, 34 p. [avail. at https://www.nwfsc. noaa.gov/assets/26/7003_05212012_091315 Gessel.et.al.1990.pdf ]
} 


\section{Phase 4: Research and Development to Improve FGE and OPE at Lower Granite Dam, 1982-85}

In 1982, following analyses and planning in 1980-81, FGE studies with fyke nets began at Lower Granite Dam, as well as additional OPE studies based on recent results of OPE studies at McNary Dam (Swan et al. ${ }^{47}$ ). To complement the FGE studies, new vertical distribution studies with fyke nets were conducted in turbine intakes to estimate the percentage of fish that passed above the area of flow that the STS was estimated to intercept and to develop TFGE estimates. For evaluation of actual FGE, a full array of fyke nets was placed below STS so that an absolute measure of FGE was determined. The results from studies indicated that the TFGE was $76 \%$ for Chinook salmon and $92 \%$ for steelhead, while the average FGE (over six test conditions) was an unacceptable $50.7 \%$ for Chinook salmon, but $73.5 \%$ for steelhead. The minimum acceptable FGE level was set at $70 \%$. The OPE of the $20.3 \mathrm{~cm}$ diameter orifices was unacceptable for Chinook salmon and steelhead; averaging $60.5 \%$ and $24 \%$, respectively.

Additionally, intermittent operation of STS was conducted at Lower Granite (as it was at McNary Dam in 1982) to determine if it were possible to decrease screen operation while not impacting fish quality. Early in the spring and summer run, intermittent STS operation-15 minutes off and $1.5 \mathrm{~min}$ utes on-was tested (McCabe and $\mathrm{Krcma}^{48}$ ). It did not increase impinge-

\footnotetext{
${ }^{47}$ Swan, G. A., R. F. Krcma, and F. J. Ossiander. 1983. Studies to improve fish guiding efficiency of traveling screens at Lower Granite Dam. Report to U.S. Army Corps of Engineers, Walla Walla District by NOAA, Natl. Mar. Fish. Serv., Seattle, 20 p. [avail. at http://www.nwfsc.noaa. gov/assets/26/7301 07162012091738 Swan. et.al.1983.pdf ].

${ }^{48}$ McCabe, G. T., and R. F. Krcma. 1983. Effects of intermittent operation of submersible traveling screens on juvenile, salmonids, 1982. Report to U.S. Army Corps of Engineers, Walla Walla District by NOAA, Natl. Mar. Fish. Serv., Seattle, 29 p. [avail. at http://www.nwfsc.noaa.gov/assets/26/7173_07042012_101215_McCabe.and. Krcma.1983.p̄df ]
}

ment rates for yearling Chinook salmon and steelhead or descaling rates when compared to fulltime operation.

Based on the 1982 studies, during the fall the USACE contracted a hydraulic model study of a turbine intake at Lower Granite Dam. The model study found that the STS deflected a larger than expected proportion of flow downward and theoretically caused the lower than expected FGE. As potential solutions, some additional hydraulic modeling indicated that raising the operating gate and lowering the STS could possibly reduce the flow deflection. An installation of at least one larger, $27.9 \mathrm{~cm}$ diameter orifice was recommended. This would provide flow with the equivalent of two $20.3 \mathrm{~cm}$ diameter orifices.

To avoid OPE bias between a north and a south orifice, it was recommended to modify a BFVBS by removing one solid plate at the top and replacing it with a porous one, with the intent to direct flow toward one orifice. While it appeared feasible to operate the STS without increasing problems for migrating fish during the spring, the practice was not accepted as a general guideline by fisheries agencies because of an inability to monitor STS continuously to determine if screening systems would begin to plug up over short time periods.

In 1983, several different conditions were tested to potentially improve FGE (Swan et al. ${ }^{49}$ ). The STS was tested in a standard and lowered $0.6 \mathrm{~m}$ position. The latter condition increased the throat opening from 0.9 to 1.5 $\mathrm{m}$, which allowed more flow to pass through the gap area. Results of testing indicated that lowering the screen had little to no effect on FGE. When the solid plate of the STS behind the traveling mesh was replaced with a perforated plate to increase the porosity of the STS, the gap net catch decreased,

\footnotetext{
${ }^{49}$ Swan, G. A., R. F. Krcma, and F. J. Ossiander. 1984. Research to develop an improved fingerling protection system at Lower Granite Dam. Report to U.S. Army Corps of Engineers, Walla Walla District by NOAA, Natl. Mar. Fish. Serv., Seattle, 27 p. [avail. at http://www.nwfsc.noaa. gov/assets/26/7302_07162012_092658_Swan. et.al.1984.pdf ].
}

which suggested more fish migrated above the screen and potentially fewer impinged on the screen. The different STS combinations were tested with the operating gate in the standard, 1.5 $\mathrm{m}$ and $6.1 \mathrm{~m}$ raised position.

Interestingly, FGE was higher for Chinook salmon when the migration was comprised of mostly Chinook salmon; likewise, FGE was higher for steelhead when the catch was comprised mostly of steelhead. This suggested some behavioral interaction between species may have resulted in different vertical distributions of the fish within the water column. While raising the operating gate increased flow into the bulkhead gateslot, and increased FGE significantly over the control condition, only the operating gate raised $6.1 \mathrm{~m}$ led to $\mathrm{FGE}$ levels $>70 \%$ for yearling Chinook salmon. All steelhead FGE levels were above $80 \%$ for all raised gate positions.

The OPE of a single $30.5 \mathrm{~cm}$ diameter orifice was tested with different combinations of plates on a balancedflow vertical barrier screen. Descaling rates of fish in gatewells were low in all the different screen and operating gate configurations. The single $30.5 \mathrm{~cm}$ diameter orifice had about the same OPE as the combined two $20.4 \mathrm{~cm}$ diameter orifices for Chinook salmon and steelhead. For the former, OPE averaged approximately $70 \%$, but for the latter only about $50 \%$. These values were below the minimum target of $75 \%$.

Based on the 1983 studies, it was recommended to permanently raise the operating gate $6.1 \mathrm{~m}$ or remove it entirely from the operating gateslot. However, it was clear that raising the gate increased flow turbulence in the bulkhead gateslot, and additional tests on the effects of the increased flow on OPE were needed.

In 1984, FGE at Lower Granite Dam was again tested, but this time with the operating gate raised $18.8 \mathrm{~m}$ (Swan et al. ${ }^{50}$ ). This height was hy-

\footnotetext{
${ }^{50}$ Swan, G. A., R. F. Krcma, and F. J. Ossiander. 1985. Development of an improved fingerling protection system for Lower Granite Dam - 1984. Final Report to U.S. Army Corps of Engineers,
} 
draulically essentially similar to removing the operating gate. A new trash boom was installed in the forebay of the dam and especially during high spill, it appeared to adversely impact FGE for Chinook salmon but not for steelhead whose measured FGE values consistently were above $80 \%$. In late April with spill of $40 \%$, however, FGE for Chinook averaged only $37 \%$. When spill decreased to $25 \%$ of flow in early May, FGE of Chinook salmon averaged $65 \%$. The BFVBS did not significantly affect FGE, however, the gatewell equipped with the BFVBS did provide significantly lower descaling rates and better OPE than a gatewell equipped with VBS. Further the modified BFVBS attained OPE for Chinook salmon and steelhead of $98 \%$ and $86 \%$, respectively, with a single $30.5 \mathrm{~cm}$ diameter orifice.

Because of uncertainty about the effect of the trash boom, a version of the 1984 FGE studies was repeated in 1985 in turbine intakes $4 \mathrm{~A}$ and $4 \mathrm{~B}$ along with simultaneous vertical distribution measurements in turbine intake 4C (Swan et al. ${ }^{51}$ ). The forebay trash boom was in place for the first set of tests (five replicates) in early April, removed for the next two sets of tests (four replicates each) in late April, and then reinstalled for the remainder of the season. The raised operating gate was also tested.

As in 1984, FGE of Chinook salmon increased throughout the season. In the first three tests it averaged approximately $40 \%$ and was unchanged between the conditions with the trash boom out compared to trash boom in place. Over the first three sets of tests, FGE, however, averaged only about $67 \%$ of the TFGE. The Chinook

Walla Walla District by NOAA, Natl. Mar. Fish. Serv., Seattle, 33 p. [avail. at http://www.nwfsc. noaa.gov/assets/26/7303_07162012_093734_ Swan.et.al.1985.pdf ].

${ }^{51}$ Swan, G. A., R. F. Krcma, and F. J. Ossiander. 1986. Continuing studies to improve and evaluate juvenile salmonid collection at Lower Granite Dam - 1985. Report to U.S. Army Corps of Engineers, Walla Walla District by NOAA, Natl. Mar. Fish. Serv., Seattle, $41 \mathrm{p}$. [avail. at https://www.nwfsc.noaa. gov/assets/26/7304_11142016_124843_Swan. et.al.1986-Smolt-collection-LGR̄.pdf] salmon FGE increased to an average of $69 \%$ through the end of the season and was $85 \%$ of the TFGE, with the exception of one test on 5 May when $40 \%$ spill occurred. On that date FGE dropped to $59 \%$. For steelhead, FGE over the first three tests averaged $71 \%$ and was $85 \%$ of the TFGE. It averaged $89 \%$ for the remainder of the tests through the end of the season and was $>90 \%$ of the TFGE, with the exception of 5 May. On that date FGE decreased to $69 \%$, although this was $100 \%$ of the TFGE.

In 1985, no difference existed in FGE between conditions with the operating gate raised 6.1 or $18.8 \mathrm{~m}$. Based on measurements of smoltification levels of Chinook salmon smolts sampled in mid-May from the gatewell and fyke nets under the STS, it was theorized that changes in levels of smoltification in fish influenced the vertical distribution of fish, and this in turn could potentially explain why FGE was lower early in the season but increased later in the season (Giorgi et al., 1988). There was a good correlation between TFGE and FGE, but the difference between the two indicated that up to $35 \%$ of yearling Chinook salmon were still deflected below the STS.

\section{Summary of Phase 4 Research and Problems Identified}

The most startling result was the abysmal FGE measured for fish at the new Bonneville Dam Second Powerhouse. This was particularly puzzling because the fish passage facilities were based on seemly successful designs and studies at McNary Dam. Yet, the two powerhouses do not have exactly the same turbine intake configurations. On hindsight, it seems clear that subtleties of the turbine intake, gatewell, vertical barrier screen, and STS gatewell/turbine intake configurations at McNary Dam were all particularly favorable to attaining acceptable FGE levels of yearling salmonid smolts; whereas, slight (or not so slight) changes in these configurations led to the particularly low FGE for Chinook salmon at the new Bonneville Dam Second Powerhouse.
While not as radical, the lower FGE measured at John Day Dam also did not match previous results attained at McNary Dam when it was operated to match a John Day Dam "configuration." It was therefore concluded that potentially each dam might have different FGE if measured with a "standard" STS and VBS. This complicated the efforts to develop guidance systems for fish because it appeared that all components of a bypass system would need to be tested specifically at each dam - even at those that appeared to have nearly the same turbine intake configurations.

Clearly, studies at lower Columbia River dams, with the exception of the 1981 studies at Bonneville Dam First Powerhouse, indicated STS would not extend far enough into turbine intakes to intercept a sufficient percentage of subyearling Chinook salmon to meet the minimum standard of $70 \%$. Research at Lower Columbia River dams and at Lower Granite Dam also indicated that the amount of flow into the gatewell affected the subsequent FGE of STS. Modifying porosity of STS and raising operating gates to increase flow into gatewells generally also increased FGE; however, it also increased turbulence within gatewells. The increased turbulence increased levels of descaling for fish guided into the gatewell and also affected OPE which led to the conclusion that $30.5 \mathrm{~cm}$ diameter orifices were the minimum size needed to assure good OPE.

Testing also suggested that in most cases a BFVBS provided the best conditions for fish in gatewells and improved OPE; particularly with the modified BFVBS that had the open screening near the orifices. It also seemed clear that to increase the percentage of fish intercepted by STS would require lower or longer STS. It was not clear what it would take to improve FGE for subyearling Chinook salmon because they migrated deeper through turbine intakes than yearling fish.

Not identified was why STS's were much less effective at intercepting 
subyearling Chinook salmon than other yearling salmon species and steelhead. It appeared that maximum FGE for subyearling Chinook salmon was approximately $65 \%$ even if the TFGE was near $100 \%$. This compared to STS efficiency levels that often exceeded $80 \%$ for yearling migrants. Research in the next $10 \mathrm{yr}$ was designed to address these issues.

\section{Phase 5: Addressing Inadequacies of STS FGE, 1986-89}

\section{Lower Columbia River Dams}

In 1986, more extensive testing of different options to increase FGE for subyearling chinook occurred at McNary Dam between 23 June and 1 August (Swan and Norman ${ }^{52}$ ). The research evaluated a lowered STS, a raised operating gate, and the trash rack deflector used in the bar screen research (Fig. 11). Results were compared to simultaneous vertical distribution measurements of fish passing through the adjacent turbine intake. The results of the vertical distribution tests indicated that the average TFGE for different test conditions representing dusk to darkness periods (when $85 \%$ of fish pass turbines) ranged from $50 \%$ to $74 \%$; with average FGE for different test conditions ranging from $21 \%$ to $61 \%$.

The highest effectiveness rate (FGE/ TFGE) during of these tests was $82 \%$, and it occurred with a lowered STS, raised operating gate, and a trash rack deflector. The lowered STS by itself did not significantly improve guidance. The trash rack deflector increased FGE whether the operating gate was raised or not, and the one series that only compared FGE between daylight and darkness hours found much higher guidance during the former compared to the latter: $69 \%$ versus $26 \%$.

The same test conditions were repeated in 1987, with the addition of

\footnotetext{
${ }^{52}$ Swan, G. A., and W. T. Norman. 1987. Research to improve subyearling Chinook salmon fish guidance efficiency at McNary Dam - 1986. Report to U.S. Army Corps of Engineers, Walla Walla District by NOAA, Natl. Mar. Fish. Serv., Seattle, 34 p. [avail. at https://www.nwfsc.noaa. gov/assets/26/7296_07122012_100641_Swan.

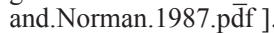

some limited testing on yearling migrants in the spring (Brege et al. ${ }^{53}$ ). In the one set of spring evaluations with a raised operating gate, trash rack deflector, and lowered STS, FGE for yearling migrants ranged from $83 \%$ to $86 \%$. The TFGE was $91 \%$, however, it was only measured on one day, and the effectiveness of the STS (FGE/ TFGE) was $87 \%$. For tests with subyearling Chinook salmon, no statistically significant differences in FGE were detected among any of the test conditions. The absolute FGE varied widely from a high of $78 \%$ to a low of $7 \%$ during the testing period.

In 1988, due to concern about low FGE of subyearling Chinook salmon at upper river dams (see next section), it was decided to evaluate FGE at Bonneville Dam First Powerhouse for summer migrants since the initial studies, conducted in 1981, had occurred in April and May, and the FGE for subyearling Chinook salmon was near or exceeded the $70 \%$ goal. Between 6 and 27 July, study results indicated that FGE and TFGE for subyearling Chinook salmon averaged only $11 \%$ and $21 \%$, respectively (Gessel et al. ${ }^{54}$ ). The abysmally low results of both FGE and TFGE plus the ongoing installation of modifications for the construction of a new navigational lock dictated a need for additional guidance tests.

In 1989, testing was conducted at Bonneville Dam First Powerhouse throughout the spring and summer salmon outmigration to monitor FGE and TFGE (Gessel et al. ${ }^{55}$ ). Results

\footnotetext{
${ }^{53}$ Brege, D. A., W. T. Norman, G. A. Swan, and J. G. Williams. 1988. Research at McNary Dam to improve fish guiding efficiency of yearling and subyearling Chinook salmon, 1987. Report to U.S. Army Corps of Engineers, Walla Walla District by NOAA, Natl. Mar. Fish. Serv., Seattle, 22 p. [avail. at https://www.nwfsc.noaa. gov/assets/26/8856_09162016_121950_Brege. et.al.1988b.pdf ].

${ }^{54}$ Gessel, M. H., B. H. Monk, D. A. Brege, and J. G. Williams. 1989. Fish guidance efficiency studies at Bonneville Dam First and Second powerhouses - 1988. Report to U.S. Army Corps of Engineers, Portland District by NOAA, Natl. Mar. Fish. Serv., Seattle, 36 p. [avail. at https://www.nwfsc. noaa.gov/assets/26/7002_05212012_085721_ Gessel.et.al.1989a.pdf ].

${ }^{55} \mathrm{Gessel}$, M. H., D. A. Brege, B. H. Monk, and J. G. Williams. 1990. Continued studies to evaluate the juvenile bypass systems at Bonneville Dam -
}

for summer tests were similar to 1988 with FGE at times $<10 \%$ for subyearling Chinook salmon migrants. More disconcerting was that mean FGE and TFGE estimates for yearling Chinook salmon were much lower than expected, $42 \%$ and $70 \%$, respectively, for a screen effectiveness of only $61 \%$. The FGE was substantially lower than the $70 \%$ measured in 1981 .

\section{Lower Snake River Dams}

In 1986, FGE studies were moved to Little Goose Dam to estimate FGE and determine the effectiveness of the STS because no direct measurements had been obtained with standard and raised operating gates, and also to determine if lower FGE occurred early in the season, as was seen at Lower Granite Dam the previous 2 yr (Swan et al. ${ }^{56}$ ). As was found at Lower Granite Dam in 1985, smoltification indices for yearling Chinook salmon sampled from gatewells (guided fish) were significantly higher than those recovered from fyke nets (unguided fish) (Giorgi et al., 1988). The FGE, however, did not vary appreciably throughout the testing. With the operating gate raised $6.1 \mathrm{~m}$, FGE averaged $74 \%$, a significant $(\mathrm{P}<0.005) \quad 13 \%$ increase from the $61 \%$ measured with the operating gate in the normal stored position.

No significant difference was detected between FGE when the operating gate was raised from $6.1 \mathrm{~m}$ to 18.8 $\mathrm{m}$. The estimated seasonal TFGE was $83 \%$ and based on FGE with the raised gate position, the seasonal effectiveness for yearling Chinook salmon was $88 \%$. The average FGE for steelhead was $79 \%$, which was $93 \%$ of the estimated TFGE. Descaling rates of year-

1989. Report to U.S. Army Corps of Engineers, Portland District by NOAA, Natl. Mar. Fish. Serv., Seattle, 34 p. [avail. at https://www.nwfsc. noaa.gov/assets/26/7003_05212012_091315 Gessel.et.al.1990.pdf ]

${ }^{56}$ Swan, G. A., A. E. Giorgi, T. Coley, and W. T. Norman. 1987. Testing fish guidance efficiency of submersible traveling screens at Little Goose Dam: Is it affected by smoltification levels. Report to U.S. Army Corps of Engineers, Walla Walla District by NOAA, Natl. Mar. Fish. Serv., Seattle, 69 p. [avail. at https://www.nwfsc.noaa. gov/assets/26/7307_11142016_122800_Swan. et.al.1987-FGE-STS-LGO-smolt.pdf ] 
ling Chinook salmon and steelhead were low, $2.1 \%$ and $0.7 \%$, respectively.

In 1986 evaluations of FGE with STS were also made at Lower Monumental Dam (Ledgerwood et al. ${ }^{57}$ ). As was found at Little Goose Dam, FGE for yearling Chinook salmon was higher with a raised operating gate compared to the standard position: $73 \%$ and $60 \%$, respectively. The FGE was, however, only $81 \%$ of the estimated 90\% TFGE. Of more concern were results for subyearling fall Chinook salmon released into the head of the Lower Monumental Dam reservoir from Lyons Ferry Hatchery. Similar to results found in the lower Columbia River, the mean FGE estimate in June was only $35 \%$ compared to an estimated $60 \%$ TFGE. This computes to an estimated STS efficiency of only $58 \%$.

In 1987, FGE tests were repeated at Little Goose Dam (Ledgerwood et $\mathrm{al}^{58}$ ). The FGE in the 3rd week of April averaged $55 \%$ for yearling Chinook salmon and $70 \%$ for steelhead (small sample sizes). By the 1st week in May, FGE had increased to an average of $70 \%$ for Chinook salmon and $87 \%$ for steelhead.

In 1987, tests at Ice Harbor Dam were also conducted to determine levels of FGE with STS and vertical barrier screen designs used at Lower Granite and Little Goose Dams (Brege et al. ${ }^{59}$ ). The STS was lowered, howev-

\footnotetext{
${ }^{57}$ Ledgerwood, R. D., G. A. Swan, and R. F. Krcma. 1987. Fish guiding efficiency of submersible traveling screens at Lower Monumental Dam - 1986. Report to the Walla Walla District, U.S. Army Corps of Engineers by NOAA, Natl. Mar. Fish. Serv., Seattle, 33 p. [avail. at https://www.nwfsc. noaa.gov/assets/26/7115_07022012_094107_ Ledgerwood.et.al.1987.pdf ].

${ }^{58}$ Ledgerwood, R. D., W. T. Norman, G. A. Swan, and J. G. Williams. 1988. Fish guiding efficiency of submersible traveling screens at Lower Granite and Little Goose Dams - 1987. Report to the Walla Walla District, U.S. Army Corps of Engineers by NOAA, Natl. Mar. Fish. Serv., Seattle, 34 p. [avail. at https://www.nwfsc.noaa.gov/assets/26/7116 07022012095029 Ledgerwood.

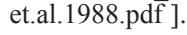

${ }^{59}$ Brege, D. A., G. A. Swan, and J. G. Williams. 1988. Fish guiding efficiency studies at Ice Harbor Dam, 1987. Report to U.S. Army Corps of Engineers, Walla Walla District by NOAA, Natl. Mar. Fish. Serv., Seattle, 20 p. [avail. at https://www.nwfsc.noaa.gov/assets/ 26/8853_09142016_181850_Brege.et.al.1988. pdf ].
}

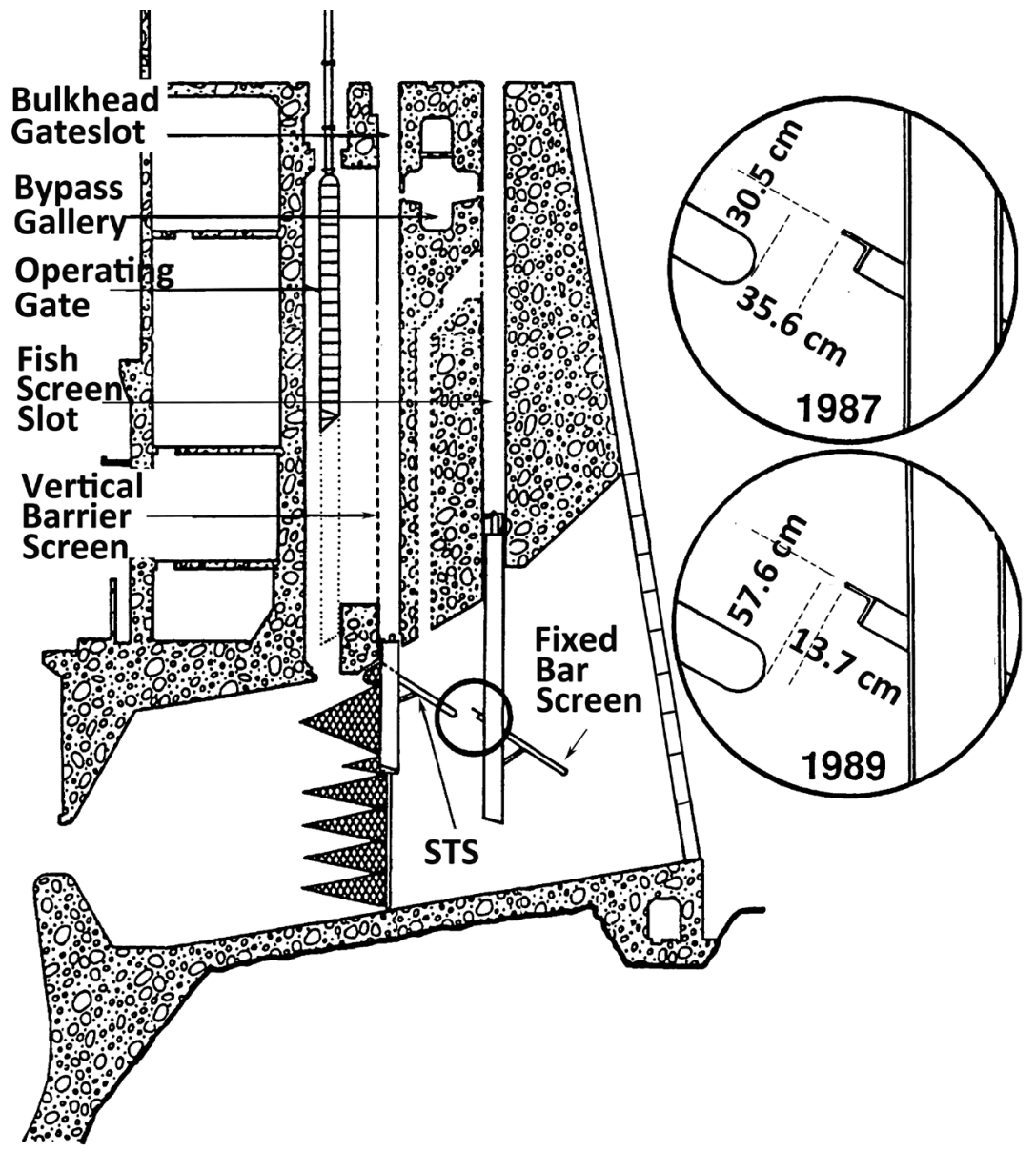

Figure 13.- Schematic of Lower Granite Dam showing configuration of installed submersible traveling screens (STS) in the bulkhead slot and fixed bar screens in the fish screen slot used in 1987 and 1989 to test a concept of a screen placed in the bulkhead gateslot that was double the length of STS evaluated.

er, $68 \mathrm{~cm}$ from the standard position. This configuration increased the throat opening and gap of the STS compared to earlier STS installations at most other projects. The operating gate was also raised $6 \mathrm{~m}$. Results were some of the best seen to date at any dam. Mean FGE for yearling Chinook salmon and steelhead were $78 \%$ and $93 \%$, respectively. The FGE values for steelhead were some of the highest ever recorded. The estimated TFGE's for yearling Chinook salmon and steelhead were also very high: $97 \%$ and $98 \%$, respectively.

In 1987, research also returned to Lower Granite Dam (Ledgerwood et al. ${ }^{58}$ ). To increase the percentage of flow intercepted, a deflector placed in the fish screen slot in conjunction with STS was tested (Fig. 13). It was not considered as a possible permanent solution, but only as a means to evaluate a potentially longer STS. The FGE under control conditions for yearling Chinook salmon and steelhead ranged from $38 \%$ to $70 \%$ and from $64 \%$ to $83 \%$, respectively. The higher values occurred later in the season and corresponded to higher levels of smoltification (Muir et al. ${ }^{60}$ ). The combination of

${ }^{60}$ Muir, W. D., A. E. Giorgi, W. S. Zaugg, W. W. Dickhoff, and B. R. Beckman. 1988. Behavior and physiology studies in relation to yearling Chinook salmon guidance at Lower Granite and Little Goose Dams, 1987. Report to U.S. Army Corps of Engineers, Walla Walla District by NOAA, Natl. Mar. Fish. Serv., Seattle, 47 p. [avail. at https://www.nwfsc.noaa. 
a $62 \mathrm{ft}$ raised operating gate, the deflector, and lowered STS increased FGE approximately $15 \%$ in 15 of 17 tests compared to the condition without the deflector. However, significantly fewer fish entered the slot with the deflector than entered the slot without it.

This led to additional testing in 1989 (Swan et al. ${ }^{61}$ ). It was critically important to determine if the fish in 1987 had only moved sideways, to avoid the hydraulic conditions in the test turbine intake, to adjacent non-deflector intakes or if, potentially, fish might also choose to avoid the conditions created by the deflector and move either to an adjacent turbine or underneath the STS/deflector combination. Therefore, the repeat testing included deflectors in all three turbine intake slots of the test unit.

Additionally the configuration of the deflector/STS interface was altered (Fig. 13) to change the hydraulics in the area because just before the 1987 tests were conducted, USACE hydraulic modeling found that a large downward flow existed in the $35 \mathrm{~cm}$ gap between the end of the STS and the tip of the deflector. The results were that fish did not move laterally from the test turbine unit with bar screen deflectors to adjacent units without them.

For yearling Chinook salmon, FGE under control conditions (no bar screen deflector) ranged from $42 \%$ to $67 \%$ and with the bar screen deflector from $60 \%$ to $81 \%$. Lower values generally occurred earlier in the season and corresponded with lower smoltification values (Muir et al. ${ }^{62}$ ). Lower FGE also

$\overline{\text { gov/assets/26/7194_07042012_131932_Muir. }}$ et.al.1988-rev.pdf ].

${ }^{61}$ Swan, G. A., B. H. Monk, J. G. Williams, and B. P. Sandford. 1990. Fish guidance efficiency of submersible traveling screens at Lower Granite Dam - 1989. Report to U.S. Army Corps of Engineers, Walla Walla District by NOAA, Natl. Mar. Fish. Serv., Seattle, 51 p. [avail. at https://www.nwfsc. noaa.gov/assets/26/8962 11142016 121207 Swan.et.al.1990-FGE-STS-LGR.pdf].

${ }^{62}$ Muir, W. D., C. S. McCutcheon, A. E. Giorgi, Zaugg W. S., Hirtzel S. R., and Beckman B. R. 1990. An assessment of the relationship between smolt development and fish guiding efficiency at Lower Granite Dam, 1989. Report to U.S. Army Corps of Engineers, Walla Walla District by NOAA, Natl. Mar. Fish. Serv., Seattle, 19 p. [avail. at https://www.nwfsc.noaa. occurred when large numbers of fish were recovered from gatewells. Results from paired treatment and control tests indicated that the deflectors significantly increased FGE by $15 \%$ and $7 \%$ for Chinook salmon and steelhead, respectively.

\section{Phase 6: Research at McNary Dam to Develop Screen Alternatives to the STS, 1991-97}

The USACE in 1990 began development of extended-length submersible traveling screens (ESTS) and extended-length submersible bar screens (ESBS) based on positive results from earlier studies at McNary and Lower Granite dams with STS and bar screen deflectors tested to simulate longer screens. The new screens were approximately double the length of the standard STS; approximately 12 $\mathrm{m}$ vs. $6 \mathrm{~m}$. The ESBS were designed with wedge-wire screening material and a mechanical arm with a brush that rotated to the bottom of the screen and then advanced up the screen to remove impinged debris. Field research of these two types of screening systems and their effect on passage configurations in gatewells was mostly conducted at McNary Dam. Variants of screens that worked successfully at McNary Dam were then tested at other dams.

The initial testing of longer screens at McNary Dam began in 1991 (Brege et al. $\left.{ }^{63}\right)$. Due to the size of the frames holding the screens, frames to hold fyke nets were put into the operating gateslot to recover fish not guided up the bulkhead gateslot and the gatewell by the ESBS or ESTS (Fig. 5). Estimated flow that ESTS and ESBS would intercept in the turbine intakes

$\overline{\text { gov/assets/26/7199_07052012_095611_Muir. }}$ et.al.1990-rev.pdf ].

${ }^{63}$ Brege, D. A., Grabowski S. J., W. D. Muir, Hirtzel S. R., Mazur S. J., and B. P. Sandford. 1992. Studies to determine the effectiveness of extended traveling screens and extended bar screens at McNary Dam, 1991. Report to U.S. Army Corps of Engineers, Walla Walla District by NOAA, Natl. Mar. Fish. Serv., Seattle, 32 p. [avail. at https://www.nwfsc.noaa.gov/ assets/26/8855_09162016_111453_Brege. et.al.1992.pdf ]. based on hydraulic model studies was applied to vertical distribution measurements of fish taken from fyke nets to attain an estimated TFGE. The extended length screens would also increase flow up the bulkhead gateslots.

To smooth flows within the gatewell caused by increased flow with longer ESBS and ESTS, modified BFVBS (Fig. 8d) were redesigned for increased gatewell flows. Results from fyke-net studies in late April indicated that the TFGE would exceed $>90 \%$ for yearling Chinook salmon, steelhead, and sockeye salmon, and in the third week of June $>90 \%$ for subyearling Chinook salmon. No vertical distribution measurements were conducted later in the summer.

In early tests, FGE for yearling Chinook salmon was $81 \%$ and $80 \%$ for ESTS and ESBS, respectively; however, unacceptably high descaling rates of $16-23 \%$ were observed with ESTS compared to descaling rates of STS of $7-8 \%$. Descaling rates of ESBS averaged about $60 \%$ of the ESTS and were slightly higher than STS. Measurements of FGE were stopped while efforts were made to alter the ESTS in order to decrease descaling rates. No changes in operating gate position, screen angle, and/or flow through the turbine unit in combination with the extended screens significantly affected descaling rates; however, some baseline descaling likely occurred because of these factors.

Varying the porosity of the perforated plate on the ESTS from $45 \%$ to $34 \%$ lowered descaling rates of ESTS to $\sim 12 \%$ and were similar to descaling rates measured in a control unit with STS. Tests of FGE that resumed in late May found FGE values for the ESTS and ESBS of $92 \%$ and $96 \%$ for steelhead, $93 \%$ and $92 \%$ for Coho salmon, $68 \%$ and $66 \%$ for sockeye salmon, and $81 \%$ and $73 \%$ for yearling Chinook salmon. The mean FGE for subyearling Chinook salmon was $64 \%$ for both the ESTS and ESBS, ranging from a high of $77 \%$ early in the season to $43 \%$ at the end. The mean was significantly higher than the $33 \%$ and $42 \%$ seasonal FGE means obtained in 1986 
and 1987, respectively, using STS. No tests of OPE were made in gateslots with extended-length screens.

In 1992, FGE tests were repeated, but only with ESBS because they caused less descaling of guided fish in 1991 (McComas et al. ${ }^{64}$ ). The ESTS was used only for descaling tests while a redesigned, more streamlined ESTS was being developed for prototype testing in 1993. To potentially increase FGE from values obtained in 1991, new test conditions were evaluated. They included changes in screen angles, height of screens below gatewells, and different perforated plate porosities in combination with different operating gate elevations. Results again indicated that FGE of ESBS for yearling and subyearling Chinook salmon were significantly better than the STS during the spring and summer migration: 80 and 53\% for the yearling and subyearling Chinook salmon, respectively, compared to 61 and $30 \%$ for the STS.

Descaling rates on yearling Chinook salmon with ESTS were, however, often more than double the descaling rates with STS. Lowering ESBS $90 \mathrm{~cm}$ below the standard elevation resulted in lower FGE because fish passed through the gap between the turbine intake ceiling and the screen. Tests with a $60 \mathrm{~cm}$ lowered screen were limited in number and did not appear to provide benefit over the standard elevation. The ESBS at standard screen elevation, set at a $55^{\circ}$ angle, with $30 \%$ perforated plate porosity, and a partially raised operating gate produced descaling rates similar to those with the STS for yearling and subyearling Chinook salmon: $12.7 \%$ vs. $10.9 \%$ and $6.6 \%$ vs. $5.1 \%$, respectively. These rates were lower than descaling rates with other ESBS configurations tested.

\footnotetext{
${ }^{64}$ McComas, R. L., D. A. Brege, W. D. Muir, B. P. Sandford, and D. B. Dey. 1993. Studies to determine the effectiveness of extended-length submersible bar screens at McNary Dam, 1992. Report to U.S. Army Corps of Engineers, Walla Walla District by NOAA, Natl. Mar. Fish. Serv., Seattle, 92 p. [avail. at https://www.nwfsc.noaa. gov/assets/26/6733_12302010_123027_McComas.et.al.1993-rev.p̄ff ].
}

No tests of OPE were made in gateslots with ESBS.

In 1993, the newly designed ESTS and the previously designed ESBS were again tested at McNary Dam (McComas et al. ${ }^{65}$ ). The old ESTS had porosities of $25 \%$ and $34 \%$, while the new ESTS had porosity of $36 \%$. The designs were set to provide an approach velocity at the screen of 0.75 $\mathrm{m} / \mathrm{s}$ and a velocity at the throat of 2.7 $\mathrm{m} / \mathrm{s}$. When all 20 nights of tests were combined for each screen type without regard to whether the operating gate was partially raised or removed, mean FGE for ESTS were significantly higher than for ESBS for yearling Chinook salmon, steelhead, and sockeye salmon: $88 \%, 93 \%$, and $85 \%$ versus $81 \%$, $91 \%$, and $73 \%$, respectively.

For yearling Chinook salmon, no significant difference in FGE or descaling was detected based upon whether the operating gate was partially raised or removed entirely. No significant differences in mean descaling rates of yearling Chinook salmon existed among ESBS, ESTS, or STS. The FGE for subyearling Chinook salmon was significantly higher with ESTS (67\%) than with ESBS (52\%) when both were used with a partially raised operating gate; however, the FGE for ESTS $(67 \%)$ was not significantly different compared to ESBS (59\%) with no operating gate. The descaling rate for ESTS (12.2\%) was significantly higher for subyearling Chinook salmon than all other operating gate/screen type combinations, including the STS. There were no significant differences among any of the other treatments

In 1994, more effort was directed at understanding the effects of bypass system configurations on levels of fish descaling. Studies over the past decade had found that raising operating gates generally increased FGE for STS, however, at the expense of increased

\footnotetext{
${ }^{65}$ McComas, R. L., B. P. Sandford, and D. B. Dey. 1994. Studies to evaluate the effectiveness of extended-length screens at McNary Dam, 1993. Report to U.S. Army Corps of Engineers, Walla Walla District by NOAA, Natl. Mar. Fish. Serv., Seattle, 109 p. [avail. at https://www.nwfsc.noaa. gov/assets/26/6734_12302010_123503_McComas.et.al.1994-rev.pdf].
}

descaling and/or decreased effectiveness of orifices to pass fish out of the gatewell. The recent FGE studies with ESTS and ESBS also increased flows into gatewells and in some cases led to higher rates of descaling. While levels of descaling were sometimes not much different between STS and ESTS or ESBS, the overall levels of descaling were often higher than seen in gatewells with no guidance screens and a stored operating gate.

Two new vertical barrier screen configurations designated VBS1 and VBS2 were tested to determine if they would decrease descaling. Rather than polyester mesh, the upstream surfaces were composed of No. 69 industry-standard profile wire, composed of $1.8 \mathrm{~mm}$ wedge-wire strands with $3.2 \mathrm{~mm}$ spaces between strands. This created an overall surface porosity of $62 \%$. On the downstream surface, vertically variable perforated plate panels were used to disperse flows within the gatewell more evenly over the entire VBS surface. Outlet flow control louvers were installed to control flow through the VBS-gatewell environment and flow deflector bases were used on both test VBS systems to smooth flows during transition into the gatewell. These VBS were compared to conditions with the modified BFVBS with and without a flow deflector (McComas et al. ${ }^{66}$ ). The configuration of the new VBS surface-solid panels and open areas - were the same as used with modified BFVBS.

Results of evaluations found that mean descaling values for yearling and subyearling Chinook salmon were not significantly different among VBS1 and VBS2 with ESBS and a control modified BFVBS used with a STS. Yearling Chinook salmon FGE with ESBS in conjunction with VBS2 was, however, significantly higher than with VBS1: $89 \%$ vs. $85 \%$, respectively. No

\footnotetext{
${ }^{66} \mathrm{McC}$ mas, R. L., B. P. Sandford, and D. B. Dey. 1995. Vertical barrier screen studies at McNary Dam, 1994. Report to U.S. Army Corps of Engineers, Walla Walla District by NOAA, Natl. Mar. Fish. Serv., Seattle, 101 p. [avail. at https://www.nwfsc.noaa.gov/assets/26/6735_12302010_124330_McComas. et.al.1995-rev.pdf ].
} 
significant differences in mean descaling values existed between polyester mesh and profile wire VBS1 surface materials for yearling and subyearling Chinook salmon.

In 1995, efforts were again primarily directed at evaluating descaling rates of yearling and subyearling Chinook salmon (McComas et al ${ }^{67}$ ). Tests were conducted on two new alternative beam extensions with newly designed VBS systems and an ESBS with an inlet flow vane. The two new configurations were compared against the control condition of the now standard McNary Dam configuration of STS, modified BFVBS, and raised operating gate. Additionally, OPE was tested under the conditions that occurred in the gatewell with these particular screen and VBS conditions.

The control condition had significantly higher yearling Chinook salmon descaling rates than for either beam extension treatment used with ESBS and inlet flow vanes. No significant difference in mean descaling values was found for subyearling chinook among the test and control conditions. There was no significant difference in mean descaling values for yearling and subyearling Chinook between either of the test conditions. The OPE averaged $74 \%, 92 \%, 93 \%$, and $87 \%$ for yearling Chinook salmon, steelhead, coho salmon, and sockeye salmon, respectively, in the gatewell using ESBS and VBS2 with an inlet flow vane. No significant difference existed between OPE values for the north and south orifices. Differences in mean descaling values between gatewell and orifice traps for yearling and subyearling Chinook salmon were not significant.

Based on research and testing of screening systems at McNary Dam from 1991 to 1995, ESBS with a flow vane, a modified VBS, and the operating gate removed provided the highest

\footnotetext{
${ }^{67}$ McComas, R. L., B. P. Sandford, and D. B. Dey. 1997. Descaling and orifice passage efficiency studies at McNary Dam, 1995. Report to U.S. Army Corps of Engineers, Walla Walla District by NOAA, Natl. Mar. Fish. Serv., Seattle, 35 p. [avail. at https://www.nwfsc.noaa.gov/ assets/26/5424_12122016_150047_McComas. et.al.1997-OPE-McNary-95.pdf ].
}

level of FGE. As a result, in 1996 the USACE installed ESBS in all turbine intake units at the dam. Subsequent to their installation, a reevaluation of the emergency turbine safety procedures found that it was necessary to have the operating gates remain in the gateslots instead of being removed entirely from the slots (the operating condition for which the ESBS guidance system was developed). Recognizing that the operating gate remaining in the gateslot would change the hydraulic conditions within the gatewell, the USACE conducted hydraulic modelling on a partially raised operating gate.

The results led to changing the VBS. The effect of the change was evaluated in 1997 along with how different levels of turbine discharge and changes of flow into the gatewell from an outlet flow-control device would affect levels of OPE and fish descaling (Brege et al. ${ }^{68}$ ). Turbine discharge was evaluated because during the juvenile fish passage season turbines are supposed to operate within $1 \%$ of peak efficiency. At McNary Dam, that translates into turbines producing essentially between $60-75 \mathrm{MW}$ of power. The difference between the lower and upper bounds equates to turbine discharge of between approximately 224 and $348 \mathrm{~m}^{3} / \mathrm{s}$, depending on head.

Higher turbine discharges cause higher water velocities within turbine intakes and greater flows into the gatewell with resultant higher velocity. Results of studies found that mean OPE for yearling and subyearling Chinook salmon was significantly higher at the $75 \mathrm{MW}$ load than at the $60 \mathrm{MW}$ load, but also descaling rates were significantly higher. With the flow control device limiting the flow into the gatewell, OPE was lower, but descaling rates were also lower.

\footnotetext{
${ }^{68}$ Brege, D. A., Absolon R. F., B. P. Sandford, and D. B. Dey. 1998. Studies to evaluate the effectiveness of vertical barrier screens and ouitlet flow-control devices at McNary Dam, 1997. Report to U.S. Army Corps of Engineers, Walla Walla District by NOAA, Natl. Mar. Fish. Serv., Seattle, 37 p. [avail. at https://www.nwfsc.noaa. gov/assets/26/6732_12202010_174807_Brege. et.al.1998.pdf ].
}

\section{Phase 6: Part Two, System-wide tests of ESTS and/or ESBS}

In 1993, ESTS and ESBS were tested at Little Goose Dam (Gessel et al. ${ }^{69}$ ). Because Little Goose Dam has higher intake velocities than McNary Dam, testing of screens with a lower porosity was needed to limit approach velocities at the screen to the required $0.75 \mathrm{~m} / \mathrm{s}$. In 1993, the ESTS and ESBS were tested with porosities of $22 \%, 25 \%$, and $28 \%$. Initial testing found that none of the porosities created unacceptable levels of descaling and thus, further testing was allowed. Constraints resulting from the listing of Snake River sockeye and spring/ summer Chinook salmon under the U.S. Endangered Species Act influenced the FGE and descaling evaluations because it limited the number of fish that researchers could handle and the potential number that could be collected in fyke nets.

Because of the unusually high ratios of wild to hatchery yearling Chinook salmon, high river flows, and a delay in the outmigration of approximately 2 weeks, only a portion of the desired number of FGE tests were conducted. Test results of ESTS and ESBS had similar values and the combined mean FGE was $85 \%$ and $90 \%$ for yearling Chinook salmon and steelhead, respectively, for the tests successfully completed. The STS had a mean FGE of $74 \%$ and $95 \%$ for yearling Chinook salmon and steelhead, respectively. The mean rate of descaling for yearling Chinook salmon was significantly higher with ESTS (12\%) than with ESBS (9\%) and STS (7\%). No significant difference in mean descaling existed between the ESBS and STS. Descaling rates for steelhead ranged from $\sim 5 \%$ prior to mid-May, $15 \%$ in late May, and $25 \%$ by early June,

\footnotetext{
${ }^{69}$ Gessel, M. H., B. P. Sandford, and D. B. Dey. 1994. Studies to evaluate the effectiveness of extended length screens at Little Goose Dam, 1993. Report to U.S. Army Corps of Engineers, Walla Walla District by NOAA, Natl. Mar. Fish. Serv., Seattle, 42 p. [avail. at https://www.nwfsc.noaa. gov/assets/26/7005_05212012_093420_Gessel. et.al.1994.pdf ].
} 
but, no significant difference existed among the screen types.

In 1994, FGE and descaling evaluations were repeated at Little Goose Dam because of the limited testing that occurred the previous year (Gessel et al. $^{70}$ ). However, only 10 FGE evaluations rather than the 20 originally planned were conducted and only ESBS were tested with fyke nets because of concern about effects on listed wild fish. The ESBS porosities tested were $25 \%$ and $28 \%$. Descaling evaluations were made for STS, ESBS, and one ESTS. None of the descaling results for the two extendedlength screen types or the STS were statistically different for yearling Chinook salmon or steelhead. Descaling rates averaged $7.6 \%$ and $5.4 \%$, respectively. For yearling Chinook salmon, no statistical difference existed in FGE between the two porosities and the combined mean FGE was $76 \%$. For steelhead, the mean FGE was significantly higher (92\% vs. $88 \%)$ for the $25 \%$ vs. $28 \%$ porosity ESBS.

In 1993 and 1994, tests with ESBS and ESTS were also conducted at The Dalles Dam (Brege et al. ${ }^{71}$; Absolon et al. ${ }^{72}$ ). In 1993, ESBS, ESTS, and STS were tested in three of the lower-flow capacity turbine units installed originally in 1960 on the west end of the powerhouse, and in 1994 three of the higher-flow capacity turbines installed in 1973 on the east end of the power-

\footnotetext{
${ }^{70}$ Gessel, M. H., B. P. Sandford, and D. B. Dey. 1995. Studies to evaluate the effectiveness of extended-length screens at Little Goose Dam, 1994. Report to U.S. Army Corps of Engineers, Walla Walla District by NOAA, Natl. Mar. Fish. Serv., Seattle, 33 p. [avail. at https://www.nwfsc.noaa. gov/assets/26/7006_05212012_093752_Gessel. et.al.1995.pdf ].

${ }^{71}$ Brege, D. A., R. F. Absolon, B. P. Sandford, and D. B. Dey. 1994. Studies to evaluate the effectiveness of extended-length screens at The Dalles Dam, 1993. Report to U.S. Army Corps of Engineers, Portland District by NOAA, Natl. Mar. Fish. Serv., Seattle, 72 p. [avail. at https://www.nwfsc. noaa.gov/assets/26/5598 09162016115339 Brege.et.al.1994.pdf ]

${ }^{72}$ Absolon, R. F. D. A. Brege, B. P. Sandford, and D. B. Dey. 1995. Studies to evaluate the effectiveness of extended-length screens at The Dalles Dam, 1994. Report to U.S. Army Corps of Engineers, Portland District by NOAA, Natl. Mar. Fish. Serv., Seattle, 69 p. [avail. at https://www.nwfsc. noaa.gov/assets/26/5599_08082014_120556 Absolon.etal.1995.pdf ].
}

house. In both years, the porosity of the tested STS was the standard $48 \%$. In 1993, the porosity of ESBS and ESTS ranged from $45 \%$ to $55 \%$ and from $49 \%$ to $54 \%$, respectively, and in 1994 from $25 \%$ to $35 \%$ and from $39 \%$ to $44 \%$, respectively.

In 1993, FGE for yearling Chinook salmon was $73 \%, 60 \%$, and $44 \%$ for ESBS, ESTS, and STS, respectively, for steelhead $83 \%, 67 \%$, and $62 \%$, respectively, and for subyearling Chinook salmon 59\%, 51\%, and $23 \%$, respectively. Descaling rates were not significantly different between any of the screens and averaged 4.6\%. In 1994, mean FGE for ESBS was $69 \%$ and ESTS $65 \%$, but were not significantly different for yearling Chinook salmon. Although mean descaling rates were low for all three screen types, the $3.2 \%$ for ESBS and $3.4 \%$ for ESTS were significantly higher than the $0 \%$ STS for yearling Chinook salmon. For subyearling Chinook salmon, mean FGE of 54\% for ESBS was significantly higher than $47 \%$ for ESTS. For subyearling Chinook salmon, ESTS had a significantly higher mean descaling rate $(3.3 \%)$ than ESBS $(1.8 \%)$ or STS $(0.7 \%)$. There was no significant difference between the descaling rates of ESBS and STS. To help assess the results from the 1993 and 1994 studies, the horizontal distribution of fish passing The Dalles Dam was made in 1994. Results indicated that juvenile salmonid passage was considerably higher in the west turbine units of the powerhouse than in either the center or east units.

In 1995, studies were conducted at Lower Granite Dam to determine if good OPE conditions would exist with the use of the VBS and ESBS configuration determined to provide the best conditions at McNary Dam in 1994 (Monk et al. ${ }^{73}$ ). Evaluations

\footnotetext{
${ }^{73}$ Monk, B. H., B. P. Sandford, and D. B. Dey. 1997. Evaluation of orifice passage efficiency and descaling with an extended-bar screen, new vertical barrier screen, and inlet flow vane at Lower Granite Dam, 1995. Report to U.S. Army Corps of Engineers, Walla Walla District by NOAA, Natl. Mar. Fish. Serv., Seattle, 25 p. [avail. at https://www.nwfsc.noaa.gov/ assets/26/6761_08022011_131503_Monk.

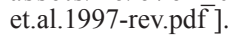

found that when this set up was used at Lower Granite Dam, OPE was over $90 \%$ for yearling Chinook salmon and steelhead. There was no statistically significant difference in OPE between the north and south orifices. Descaling with the test guidance devices was < $1 \%$ for yearling Chinook salmon and $<4 \%$ for steelhead, and these values were not significantly different from descaling measured with STS during the same period. During three OPE tests using orifice traps, approximately $50 \%$ of the daily juvenile salmonid passage occurred between $2000 \mathrm{~h}$ and $2400 \mathrm{~h}$.

\section{Bonneville Dam Conundrum}

At the new Bonneville Dam Second Powerhouse, none of the research throughout the mid- to late 1980's materially improved FGE (Gessel et al., 1991). No clear resolutions to the problem with low FGE were identifiable. At Bonneville Dam First Powerhouse, the evaluations during 1988-89 found lower than expected FGE compared to the initially favorable levels observed with prototype STS in 1981. The initial speculation was that it resulted from changes in the forebay of the powerhouse related to construction of a new navigational lock at the dam site.

In 1991, renewed FGE testing began across the entire powerhouse, with additional testing of a raised operating gate. Results indicated that during the early part of the spring outmigration, FGE for yearling Chinook salmon varied within and among turbine units and ranged from $19 \%$ to $67 \%$; all estimates below the minimum $70 \%$ target level (Monk et al. ${ }^{74}$ ). Tests did find that raising the operating gate in Unit 8 significantly increased FGE for yearling Chinook salmon, from $30 \%$ to $50 \%$.

\footnotetext{
${ }^{74}$ Monk, B. H., Varney G. E., and Grabowski S. J. 1992. Continuing studies to evaluate and improve submersible traveling screens for fish guidance at Bonneville Dam First Powerhouse-1991. Report to U.S. Army Corps of Engineers, Portland District by NOAA, Natl. Mar. Fish. Serv. Seattle, 20 p. [avail. at https://www.nwfsc.noaa. gov/assets/26/7178_07042012_104908_Monk et.al.1992b-rev.pdf ]
} 
Additional testing occurred in 1992 with a lowered STS, but results did not improve over those found with the raised operating gate in 1991 (Monk et al. ${ }^{75}$ ). Also, contrary to results obtained in 1991, raising the operating gate did not significantly improve FGE for yearling Chinook salmon; however, it did significantly increase FGE for subyearling Chinook salmon, Coho salmon, and steelhead although again FGE for several blocks of tests did not reach the minimum goal of $70 \%$. Additionally, both FGE and TFGE for subyearling Chinook showed a progressive decline throughout the field season.

Efforts were then again directed at the Bonneville Second Powerhouse. Studies in the 1980's had all been conducted in Turbine Unit 12, but recommendations at the time to increase FGE at the powerhouse were not implemented and tested. In 1993, tests of FGE in south, middle, and north turbine units, under full and partial powerhouse operation for spring and summer migrations were conducted to evaluate modifications to the powerhouse proposed previously-alternating turbine intake extentions (TIE) between gateslots, lowered STS's, and streamlined trash racks (Monk et al. ${ }^{76}$ ). Results were still disappointing.

For yearling Chinook salmon during the spring migration, with 4-6 turbines operating, mean FGE was $44 \%$ and with eight turbines it was $50 \%$. Over the same turbine operating conditions, the range of FGE for all other species ranged from only $35 \%$ to $60 \%$.

Turbine operations influenced where

\footnotetext{
${ }^{75}$ Monk, B. H., Ross J. A., B. P. Sandford, and D. B. Dey. 1993. Continuing studies to measure and improve fish guidance efficiency of submersible traveling screens at Bonneville Dam First Powerhouse, 1992. Report to U.S. Army Corps of Engineers, Portland District by NOAA, Natl. Mar. Fish. Serv., Seattle, 32 p. [avail. at https://www.nwfsc. noaa.gov/assets/26/6182_11072016_143026_ Monk.et.al.1993-FGE-STSs.pdf ].

${ }^{76}$ Monk, B. H., B. P. Sandford, and D. B. Dey. 1994. Evaluation of fish guidance efficiency of submersible traveling screens and other modifications at Bonneville Dam Second Powerhouse, 1993. Report to U.S. Army Corps of Engineers, Portland District by NOAA, Natl. Mar. Fish. Serv., Seattle, 48 p. [avail. at https://www.nwfsc. noaa.gov/assets/26/6760_08022011_130754 Monk.et.al.1994-rev.pdf ]
}

fish passed the dam. Results indicated that the fewer the number of turbines operating, the greater the percentage of fish that entered a gateslot without a TIE. During the summer migration, with four or six turbine units in operation, FGE for subyearling Chinook salmon ranged from $23 \%$ to $42 \%$ (nonTIE slots) and was significantly higher with six units in operation than with four. In 1994, tests were repeated with a more limited turbine operation and FGE was measured only in non-TIE turbine intakes (Monk et al. ${ }^{77}$ ). Results were essentially the same as in 1993.

A complete review of all studies associated with FGE at the Bonneville Second Powerhouse was completed in 1999 (Monk et al. ${ }^{78}$ ). While it provided some possible explanations for the poor FGE levels that existed at the dam, because precise data on nearfield behavior of migrating fish arriving at the powerhouse and how fish interacted with the hydraulic conditions they encountered was not known, the review could not attribute the low guidance to any particular factors at the dam.

Finally, to address low FGE found at Bonneville First Powerhouse, ESBS with raised operating gates were tested in 1998, along with assessing how these conditions might potentially affect OPE and descaling (Monk et al. ${ }^{79}$ ). In the spring, FGE for yearling and subyearling Chinook salmon aver-

\footnotetext{
${ }^{77}$ Monk, B. H., B. P. Sandford, and D. B. Dey. 1995. Evaluation of fish guidance efficiency of submersible traveling screens and other modifications at Bonneville Dam Second Powerhouse, 1994. Report to U.S. Army Corps of Engineers, Portland District by NOAA, Natl. Mar. Fish. Serv., Seattle, 29 p. [avail. at https://www.nwfsc. noaa.gov/assets/26/7180_07042012_110617_ Monk.et.al.1995-rev.pdf ].

${ }^{78}$ Monk, B. H., M. H. Gessel, and Ferguson J. W. 1999. An evaluation of the biological database for improving fish guidance efficiency at Bonneville Dam Second Powerhouse. Report to U.S. Army Corps of Engineers, Portland District by NOAA, Natl. Mar. Fish. Serv., Seattle, 62 p. [avail. at https://www.nwfsc.noaa. gov/assets/26/6762_08022011_132022_Monk. et.al.1999-rev.pdf ].

${ }^{79}$ Monk, B. H., B. P. Sandford, and D. B. Dey. 1999. Evaluation of extended-length submersible bar screens at Bonneville Dam First Powerhouse, 1998. Report to U.S. Army Corps of Engineers, Portland District by NOAA, Natl. Mar. Fish. Serv., Seattle, 48 p. [avail. at https://www.nwfsc.
}

aged $72 \%$ and $67 \%$, respectively. For steelhead, coho salmon, and sockeye salmon FGE averaged $85 \%, 80 \%$, and $51 \%$, respectively. During the same time period, in a comparison between the test conditions and a control STS with stored operating gate, OPE for yearling Chinook salmon was $90 \%$ and $80 \%$, respectively.

A significant difference existed between the descaling rates of $10 \%$ for spring Chinook salmon with the ESBS test conditions compared to $8 \%$ for the standard STS condition. No significant differences in descaling rates existed between the two conditions for subyearling Chinook salmon, steelhead, coho salmon, or sockeye salmon. During summer evaluations of subyearling Chinook salmon, FGE averaged 55\% from 22 to 27 June, but dropped to $27 \%$ from 29 June to 17 July. The values were much higher than the average FGE of $11 \%$ and $4 \%$, respectively, during similar periods in 1988 and 1989. During the summer migration, OPE averaged 97\% with the ESBS and $98 \%$ with the standard STS and descaling values averaged $3 \%$ with the ESBS and 2\% with the standard STS.

\section{Phase 7: Implementation}

Nearly all field research to test and develop screening systems for turbine intakes or orifices in gatewells was conducted by BCF-NMFS. When research results indicated configurations of screens and/or orifices would potentially increase the percentage of fish that would pass a non-turbine route, the information was considered by the USACE and fishery agencies. Recommendations/decisions were made about implementing those that appeared promising. The USACE would then include costs in budgets submitted to Congress.

Installation of systems and/or parts to systems began in 1968. The turbine intake screening systems and orifice combinations installed at USACE dams on the Lower Snake and Colum-

noaa.gov/assets/26/6582_07202010_121023 Monk.et.al.1999-rev.pdf ]. 
bia Rivers were essentially completed in 1997 (Table 1). Complete turbine intake screening systems or retrofits to ESBS from STS, after taking into account the expected decrease in turbine mortality that would occur for populations of fish passing a dam, were not installed at all powerhouses.

A few small changes to installed systems were made after 1997. The original ESBS had perforated plates attached to the downstream side to balance flow so that juvenile salmon were not impinged on the face of the guiding device. The perforated plate was bolted or welded to the framework that supports the ESBS. Within a year of use, in some instances, vibration caused by flow through the perforated plate caused the bolts or welds to break. Hydraulic model studies, conducted at the Iowa Institute of Hydraulic Research, indicated that changing the perforated plate to one that had $30^{\circ}$ full-chamfered perforations would dampen the vibration.

In 1999, research was conducted at Lower Granite Dam in the spring and McNary Dam in the summer to evaluate such a perforated plate design against the original design to determine if it would affect condition of fish diverted by ESBS into the bulkhead slot gatewell (Gessel et al. ${ }^{80}$ ). The condition of fish guided by ESBS with the new design was also observed at Little Goose Dam. Results from the comparative studies found that the changed perforation did not increase descaling and/or injury to the fish compared to the standard perforated plate. At Little Goose Dam, the long-term (19 h) descaling for yearling Chinook salmon was significantly lower with the chamfered plate, indicating that the new design might have also decreased turbulence in the gatewell.

\footnotetext{
${ }^{80}$ Gessel, M. H., B. H. Monk, B. P. Sandford, and J. W. Ferguson. 2000. Evaluation of a chamfered perforated plate for extended-length bar screens at Little Goose and McNary dams, 1999. Report to U.S. Army Corps of Engineers, Walla Walla District by NOAA, Natl. Mar. Fish. Serv., Seattle, 23 p. [avail. at https://www.nwfsc.noaa. gov/assets/26/6553 07122010_100734_Gessel. et.al.2000a-rev.pdf ].
}

Table 1.-Installation of turbine intake screens, orifices, and vertical barrier screens (VBS) at USACE operated dams on the Lower Snake and Columbia River dams, 1969-97.

\begin{tabular}{|c|c|c|c|c|c|c|}
\hline Dam & $\begin{array}{l}\text { Screen } \\
\text { type (no.) }\end{array}$ & $\begin{array}{c}\text { Year } \\
\text { installed }\end{array}$ & $\begin{array}{c}\text { Orifice } \\
\text { diameter (cm) } \\
\text { [no./gatewell] }\end{array}$ & $\begin{array}{c}\text { Year } \\
\text { installed }\end{array}$ & VBS type & $\begin{array}{c}\text { Year } \\
\text { installed }\end{array}$ \\
\hline Bonneville First & None & & & 1969 & None & \\
\hline Bonneville Second & STS & 1982 & $30.5(2)$ & 1982 & BFVBS & \\
\hline The Dalles & None & & $15.2(1)$ & 1969 & None & \\
\hline John Day & & & $15.2(1)$ & 1969 & VBS & 1985 \\
\hline John Day & STS & $1985-86$ & $35.6(1)$ & $1985-86$ & MBFVBS & $1985-86$ \\
\hline McNary & STS (3) & 1978 & $15.2(2)$ & $1968-69$ & VBS (9) & 1978 \\
\hline McNary & STS (39) & 1981 & $30.5(2)$ & 1981 & VBS (33) & 1979 \\
\hline McNary & ESBS & 1997 & & & MBFVBS (42) & 1997 \\
\hline Ice Harbor & STS (24) & $1992-93$ & $15.2(1)$ & 1970 & MBFVBS & 1992 \\
\hline Ice Harbor & & & $35.6(2)$ & $1992-93$ & MBFVBS & 1992 \\
\hline Lower Monumental & STS (18) & 1992 & (24) $15.2(1)$ & 1969 & & \\
\hline Lower Monumental & & & (24) 30.5 (2) & 1991 & & \\
\hline Little Goose & STS (6) + (13) & $1973 \& 1981$ & $15.2[1]$ & 1969 & VBS (9) & $1973 \& 1981$ \\
\hline Little Goose & ESBS (18) & 1997 & $30.5[1]$ & 1984 & MBFVBS2 & 1997 \\
\hline Lower Granite & STS (9) & $1975-76$ & $20.3[2]$ & 1975 & VBS (3) \& (6) & $1975-76$ \\
\hline Lower Granite & STS (18) & 1978 & 25.4 [2] & 1990 & MBFVBS & 1976 \\
\hline Lower Granite & ESBS (18) & 1997 & & & MBFVBS2 & 1997 \\
\hline
\end{tabular}

\section{Discussion}

The research to develop effective turbine intake screens to guide/divert juvenile salmon away from turbines and into gatewells, vertical barrier screens to hold fish within gatewells, and orifices to provide a safe passage route from gatewells took much longer than initially envisioned in the 1960's. We ascribe this to the following two general factors.

First, throughout nearly the entire 30-y period of testing, biologists lacked detailed knowledge on how juvenile salmonids responded to variations in flow and velocity. Without this, they could not provide engineers the specific criteria needed to design effective screens and orifices. Additionally, engineers did not know how equipment would affect hydraulic conditions on a scale fine enough so that it could be matched with results from biological testing. As a result, although most tests in the first couple of decades were conducted based on the best intuition about how fish would respond to hydraulic conditions they encountered, when a piece of test equipment didn't work as presumed, it was often unclear as to why.

Second, the period for successful testing of research equipment was limited to times when migrant fish were in the river. For yearling migrants, this generally limited testing to the months of April and May. For subyearling mi- grants, tests were generally limited to a 60-day window from late June into late August. These limited time periods strained the ability to conduct field research with sufficient replication to meet good experimental design for more than a few different test conditions per year. This also made it difficult to compensate for late delivery or breakdown of equipment. Finally, because of test equipment size, in cases where it was clear early in a testing season that results were not nearly as good as expected, it was generally not possible to make any alterations to the equipment in time to re-test within a migration year.

As a consequence of these two major factors, annual incremental increases in knowledge and/or increases in FGE or OPE with concomitant low levels of descaling were often small to none-even after months of planning, design, and construction of new test equipment based on the best knowledge of dozens of biologists and engineers working to develop the new equipment to test. Most discouragingly, sometimes test equipment worked well at one site or under one particular condition, which then implied that a bypass solution was found. Subsequently, tests were scheduled at another dam, but similar positive results were not obtained. The most glaring example occurred at Bonneville Dam Second Powerhouse where tens of millions of dollars spent on fish passage 
facilities failed to meet passage criteria, yet they were designed based on what were considered good FGE and passage conditions at McNary Dam.

Initially, field studies attempted to determine FGE or OPE for all salmonid species, but often the variety of test conditions plus the ever changing juvenile salmonid population made this impossible. For any one test, it could often lead to over-sampling of some species and under sampling others. The former led to unnecessary handling and incidental mortality, and the latter, too few fish to provide sufficient statistical precision. Thus, testing was focused on yearling spring Chinook salmon in the spring and subyearling Chinook salmon in the summer.

Data for steelhead, coho salmon, and sockeye salmon were collected and evaluated as available. Fishery agencies and tribes also began limiting field research to decrease the number of fish handled in dip nets and sacrificed in fyke nets. The fyke nets used to capture nonguided fish resulted in $100 \%$ mortality. To decrease fyke-net mortality, testing protocol was changed to use only the center row of nets. This change was based on analyses of initial FGE field research with complete complements of fyke nets which found multiplying by 3 just the number of fish recovered from the center column of nets provided a reasonable estimate of the total number of nonguided fish. Further, by the mid-1980's, researchers set a target number of 250 total fish to collect for each replicate. This number included fish dipped from the gatewell plus those recovered from fyke nets.

For statistical purposes, a minimum of three replicates was needed for each test configuration. The Federal listing of Snake River sockeye salmon $\left(\mathrm{NMFS}^{81}\right.$ ) under the U.S. Endangered Species Act (ESA) in fall 1991 and

\footnotetext{
${ }^{81}$ NMFS. 1991. Endangered and threatened species; endangered status for Snake River sockeye salmon. Federal Register 56: No. 224 (November 20, 1991), p. 58619-58624. U.S. Dep. Commer., NOAA, Washington, D.C. [avail. at http://www. westcoast.fisheries.noaa.gov/protected species/ salmon_steelhead/salmon_and_steelhead_listings/sockeye/sockeye_salmon_federal_register_ notices.html ].
}

Snake River yearling and subyearling Chinook salmon(NMFS ${ }^{82}$ ) in spring 1992 placed additional onus on developing better means to divert fish away from turbines. Yet, at times, all research to obtain needed information was stopped when large percentages of wild fish were in the migration.

The listings led to consideration of trade-offs between sampling methodologies to attain FGE estimates and mortalities to test fish. Nonetheless, because the extended screens had a large impact on turbine intake flow, and preliminary analyses from research at McNary Dam indicated that the center row of nets would under estimate the number of nonguided fish, studies that evaluated FGE of extended screens used a complete array of fyke nets.

For decades, biologists were fairly certain that successful FGE and OPE, or lack thereof, were related to behavior of fish, yet the degree that behavior played in attaining successful results compared to changes in physical structures or conditions at dams was not clearly known. A review of factors effecting FGE was conducted in the mid-1990's in an effort to try to understand why researchers found such variable FGE over the previous decades (Williams et al. ${ }^{83}$ ).

Fish behavior appeared to play a large role. The review outlined laboratory studies that provided some of the first evidence that migrating juvenile Chinook salmon smolts actively avoided areas with decreasing water velocity, such as occurs upstream of guidance screens in turbine intakes. Enders et al. (2012) subsequently found that juvenile Chinook salmon

\footnotetext{
${ }^{82}$ NMFS. 1992. Threatened status of Snake River spring/summer Chinook salmon, threatened status for Snake River fall Chinook salmon. Federal Register 57: No. 78 (April 22, 1992), p. 1465314663. U.S. Dep. Commer., NOAA, Washington, D.C. [avail. at http://www.westcoast.fisheries. noaa.gov/publications/frn/1992/57fr14653.pdf ].

${ }^{83}$ Williams, J. G., M. H. Gessel, B. P. Sandford, and J. J. Vella. 1996. Evaluation of factors affecting juvenile Chinook salmon fish guidance efficiency. Report to U.S. Army Corps of Engineers, Walla Walla District by NOAA, Natl. Mar. Fish. Serv., Seattle, 35 p. [avail. at https://www.nwfsc. noaa.gov/assets/26/6850_03012012_121748 Williams.et.al.1996.pdf ].
}

also actively avoided rapidly increasing water velocity conditions. Most interestingly, the threshold change in water velocity that elicits avoidance response has a similar magnitude for increasing and decreasing water velocity conditions.

On hindsight, while the specifics of water velocity/acceleration were not specifically known, it certainly appears that they correlated with general differences in FGE and OPE attained in studies. With respect to effects of screens in turbine intakes, configuration of the intakes appeared to influence FGE. At the four oldest dams with curved ceiling intakes, in general, higher FGE has been obtained than at the five newer powerhouses with a relatively straight turbine intake ceiling (Fig. 3.) We think the higher FGE resulted from more favorable conditions as fish approached screens. The flow into turbine intakes at the older dams accelerates more gradually because of the longer curved ceilings.

We conjecture that a higher percentage of fish remained higher in the water column before approaching the decelerating water conditions caused by screens and thus, more were guided or deflected into the gatewell. In contrast, we think at dams with straight ceiling intakes, water velocity increased more rapidly farther upstream than at intakes with curved ceilings. As a result, a higher percentage of fish detected decreasing water velocities farther upstream of STS and lower FGE resulted when fish actively moved to avoid the decreasing water velocity conditions caused by screens.

The conditions in the gatewell and the size of the orifice influence the OPE. The research on orifices found that sufficient submergence and head to create water velocities of $>3 \mathrm{~m} / \mathrm{sec}$ were required to obtain high OPE values. This velocity exceeds the swimming ability of juvenile salmonid smolts. It suggests that flow into orifices traps fish.

All orifices at the same submergence and head have the same increase in water acceleration, but the area of acceleration is more abrupt in orifices with 
smaller diameter than those with a larger diameter. Fish may have detected this acceleration in the original 15.2 $\mathrm{cm}$ diameter orifices and avoided getting trapped. Since larger orifices have a greater trapping area, fish may not detect the acceleration in time to avoid it. The vertical barrier screen research led to conditions that were somewhat benign in the area of the orifices, while greater velocity and turbulence through the vertical barrier screens existed in areas away from the orifice. We think the effect was to provide "sanctuary" areas near the orifices that attracted fish, and then fish in the area were trapped by the orifice flow.

With the exception of the new Bonneville Dam Second Powerhouse, levels of FGE above $70 \%$ were nearly always attainable for steelhead with STS and raised operating gates. However, despite nearly 20 yr of research, a $70 \%$ FGE target level was often not attainable throughout the entire migration season at all dams for yearling Chinook salmon, and seldom attained $70 \% \mathrm{FGE}$ on incidental tests for sockeye salmon.

Of particular concern was the inability under nearly any circumstance to attain $70 \%$ FGE for subyearling Chinook salmon. Potentially, these general results were related to fish size. Larger fish with greater swimming abilities may not have responded to the changes in water acceleration to the same extent as did smaller fish. We do note, however, that at dams where measured, subyearling Chinook salmon FGE tended to decrease over the period from early June to August when no changes occurred in guidance systems at dams. The decrease in FGE did correspond to lower vertical distribution of fish passing into turbine intakes.

A number of modifications to the original STS tested at Ice Harbor Dam were made over the next $20 \mathrm{yr}$ and testing led to gains in FGE, however, they were not all straightforward. The 1984 study at Lower Granite Dam indicated that more than STS configurations effected FGE. The interaction of high spill attracting fish toward the spillway in connection with a $\log$ boom designed to reduce debris arriving at the dam, appeared to induce migrants in surface waters to pass through the spillway. This apparently decreased the percentage of guidable fish that entered the turbine intakes in the test unit. Thus, FGE was lower.

Secondly, FGE increased as the season progressed, yet the general test conditions remained unchanged. The changes in FGE appeared related to differences in physiology between fish stocks. Taken together, it suggested that modifications to STS alone would not sufficiently increase FGE to lower the number of fish passing through turbines.

To limit turbine passage might also require major modifications at dams, such as adding trash rack deflectors, redesigning STS, or considering other devices that could intercept a greater percentage of Chinook salmon in the water column flowing into turbine intakes. This was considered a potentially very difficult task to address when looking at the continuing poor measures of FGE after major structural modifications had been made at the new Bonneville Dam Second Powerhouse.

At the time that the initial research on screening systems for turbine intakes began in the 1960's, the dams installed in the lower Snake and Columbia rivers were designed primarily to produce power. They were built as "run of river" structures with little storage capacity. All river discharge was expected to go through turbines unless total discharge exceeded powerhouse capacity. It focused the research to develop systems to divert fish from turbine passage.

Despite completion of bypass systems at nearly all dams, the upriver salmon stocks did not rebound to historic levels. This has led to voluntary spill programs at dams as a further means of decreasing turbine passage. Had this operation scenario been in effect at the time the screening system studies began, it is not clear that all of systems now in place at each dam would have been installed.

During most of the $30 \mathrm{yr}$ of screening research, it was quite clear that fish behavior played a significant role in whether or not some screening configurations worked. Despite this recognition, the tools needed to determine fine-scale fish behavior and the resolution of hydraulic conditions on the scale at which fish responded was unknown.

In recent years, technology improvements with computers, videography, and modeling has made the ability to obtain this information feasible. Where not known, we highly recommend initially focusing efforts at quantifying fish behavior for species of interest under variable flow conditions, prior to design, construction, and installation of prototype screening systems envisioned to divert or guide fish at dams.

\section{Acknowledgments}

We thank the dozens of biologists working over decades, initially with the U.S. Department of the Interior, Fish and Wildlife Service, Bureau of Commercial Fisheries, and subsequently with the U.S. Department of Commerce, National Oceanic and Atmospheric Administration, National Marine Fisheries Service (Northwest Fisheries Science Center) whose field and laboratory research led to the juvenile salmonid passage systems now in place at Federal dams on the lower Snake and Columbia Rivers. We particularly thank those with whom we directly worked; many of whom developed the proposals and conducted the field research that this paper details: Clifford W. Long, Wesley J. Ebel, Richard F. Krcma, George A. Swan, William M. Marquette, Donn L. Park, Earl F. Prentice, Gene M. Matthews, Jim R. Smith, Tom E. Ruehle, George T. McCabe, Earl M. Dawley, Bruce H. Monk, Dean A. Brege, R. Lynn McComas, Lyle G. Gilbreath, Richard D. Ledgerwood, William D. Muir, Randal F. Absolon, Albert E. Giorgi, Douglas B. Dey, and John F. Ferguson. Our colleague Winston E. Farr provided the engineering designs for the initial STS and fyke-net frames. For installations of large equipment at dams, we are indebted to a large number of engineers and biologists from the U.S. Army 
Corps of Engineers who conducted hydraulic model studies, helped with development of prototype designs, and oversaw the modification of dams and construction of test equipment. We particularly thank John V. Elman, James E. Simonson, Phillip G. Weitz, Ira W. Brickey, Wallace C. Iceberg, William J. Ryan, Frank C. Cobb and Robert K. Manus at the NMFS shops in Pasco and Seattle, Wash., who fabricated nearly all of the test equipment in the first 2-3 decades of research, installed it in the field, and then operated cranes that handled the equipment during field testing. We are indebted to the hundreds of biological and field technicians hired to help conduct the field and laboratory tests. Willis Hobart at NOAA, Scientific Publications Office provided valuable editing. Finally, without the huge effort of Joanne Butzerin at NWFSC to make electronic copies of decades of unpublished gray literature reports available on the NOAA, Northwest Fisheries Science Center website, we could not have produced this paper.

\section{Literature Cited}

Basham, L. R., M. R. DeLarm, J. B. Athearn, and S. W. Pettit. 1982. Fish transportation oversight team annual report-FY 1981: Transportation operation on the Snake and Columbia Rivers. U.S. Dep. Commer., NOAA Tech. Memo. NMFS F/NWR-2, 58 p. +4 appendix tables.

Bates, D. W., E. W. Murphey, and E. F. Prentice. 1970. Design and operation of a cantilevered traveling fish screen (Model V). In Preliminary designs of traveling screens to collect juvenile fish, p. 6-15. U.S. Fish Wildl. Serv., Spec. Sci. Rep.-Fish. 608

Bates, D. W., and J. G. Vanderwalker. 1970. Traveling screens, for collection of juvenile salmon (Models I and II). In Preliminary designs of traveling screens to collect juvenile fish, p. 1-5. U.S. Fish Wildl. Serv., Spec. Sci. Rep.-Fish. 608

and R. Vinsonhaler. 1957. Use of louvers for guiding fish. Trans. Am. Fish. Soc. 86:38-57. (doi: https://doi. org/10.1577/1548-8659(1956)86[38:UOLFG F]2.0.CO;2).

Bentley, W. W., and H. L. Raymond. 1968. Collection of juvenile salmonids from turbine intake gatewells of major dams in the Columbia River system. Trans. Am. Fish. Soc. 97:124-126. (doi: https://doi. org/10.1577/1548-8659(1968)97[124:COJSF $\mathrm{T}] 2.0 . \mathrm{CO} ; 2)$.

$$
\text { and }
$$

1969. Passage

of juvenile fish through orifices in gatewells of turbine intakes at McNary Dam. Trans. Am. Fish. Soc. 98:723-727. (doi: https://doi.
org/10.1577/1548-8659(1969)98[723:POJFT O]2.0.CO;2).

Chapman, D. W. 1986. Salmon and steelhead abundance in the Columbia River in the nineteenth century. Trans. Am. Fish. Soc. 115:662-670. (doi: https://doi. org/10.1577/1548-8659(1986)115<662:SAS $\mathrm{AIT}>2.0 . \mathrm{CO} ; 2$ ).

Collins, G. B., C. H. Elling, J. R. Gauley, and C. S. Thompson. 1963. Effect of fishway slope on performance and biochemistry of salmonids. Fish. Bull. 63(1):221-253.

Craig, J. A., and R. L. Hacker. 1938. The history and development of the fisheries of the Columbia River. Bull. U.S. Bur. Fish. 49:133-216.

Dietrich, W. 1995. Northwest passage: the great Columbia River. Simon and Schuster, N.Y., $448 \mathrm{p}$.

Ebel, W. J. 1980. Transportation of Chinook salmon, Oncorhynchus tshawytscha, and steelhead, Salmo gairdneri, smolts in the Columbia River and effects on adult returns. Fish. Bull. 78:491-505.

D. L. Park, and R. C. Johnsen. 1973. Effects of transportation on survival and homing of Snake River Chinook salmon and steelhead trout. Fish. Bull. 71:549-563.

Enders, E. C., M. H. Gessel, J. J. Anderson, and J. G. Williams. 2012. Effects of decelerating and accelerating flows on juvenile salmonid behavior. Trans. Am. Fish. Soc. 141(2):357364. (doi: https://doi.org/10.1080/00028487.2 012.664604).

Gauley, J. E., R. E. Anas, and L. C. Schlotterbeck. 1958. Downstream movements of salmonids at Bonneville Dam. U.S. Dep. Int., Fish. Wildl. Serv., Spec. Sci. Rep.-Fish. 236, $11 \mathrm{p}$

Gauley, J. R., and C. S. Thompson. 1963. Further studies on fishway slope and its effect on rate of passage of salmonids. Fish. Bull. 63:45-62.

Gessel, M. H., J. G. Williams, D. A. Brege, R. F. Krcma, and D. R. Chambers. 1991. Juvenile salmonid guidance at the Bonneville Dam second powerhouse, Columbia River, 1983-1989. N. Am. J. Fish. Manage. 11(3):400-412. (doi: https://doi. org/10.1577/1548-8675(1991)011<0400:JSG $\mathrm{ATB}>2.3 . \mathrm{CO} ; 2)$.

Giorgi, A. E., G. A. Swan, W. S. Zaugg, T. Coley, and T. Y. Barila. 1988. Susceptibility of Chinook salmon smolts to bypass systems at hydroelectric dams. N. Am. J. Fish. Manage. 8:25-29. (doi: https://doi.org/10.1577/15488675 (1988) $008<0025:$ SOCS T $>2.3$. $\mathrm{CO} ; 2)$.

Griffin, L. E. 1935. Certainties and risks affecting fisheries connected with damming the Columbia River. Northwest Sci. 9:25-30.

Holmes, H. B., and F. G. Morton. 1939. The success of the Bonneville fishways during their first year of operation. Prog. Fish Cult. 6(45):1-11. (doi: https://doi. org/10.1577/1548-8640(1939)6[1:TSOTBF] 2.0.CO;2)

Liscom, K. L. 1971. Orifice placement in gatewells of turbine intakes for bypassing juvenile fish around dams. Trans. Am. Fish. Soc. 100(2):319-324. (doi: https://doi. org/10.1577/1548-8659(1971)100<319:OPIG $\mathrm{OT}>2.0 . \mathrm{CO} ; 2$ )

Long, C. W. 1968. Diel movement and vertical distribution of juvenile anadromous fish in turbine intakes. Fish. Bull. 66:599-609. and R. F. Krcma. 1969. Research on a system for bypassing juvenile salmon $\&$ trout around low-head dams. Comm. Fish. Rev. 31(6):27-29.

Marquette, W. M., and C. W. Long. 1971. Laboratory studies of screens for diverting juvenile salmon and trout from turbine intakes. Trans. Am. Fish. Soc. 100:439-447. (doi: https://doi. org/10.1577/1548-8659(1971)100<439:LSO $\mathrm{SFD}>2.0 . \mathrm{CO} ; 2$ )

Monan, G. E., R. J. McConnell, J. R. Pugh, and J. R. Smith. 1969. Distribution of debris and downstream-migrating salmon in the Snake River above Brownlee Reservoir. Trans. Am. Fish. Soc. 98:239-244. (doi: https://doi. org/10.1577/1548-8659(1969)98[239:DODA DS]2.0.CO;2).

Monk, B. H., D. Weaver, C. S. Thompson, and F. J. Ossiander. 1989. Effects of flow and weir design on the passage behavior of American shad and salmonids in an experimental fish ladder. N. Am. J. Fish. Manag. 9:60-67. (doi: https://doi.org/10.1577/15488675(1989)009<0060:EOFAWD >2.3. $\mathrm{CO} ; 2)$.

Netboy, A. 1980. Columbia River salmon and steelhead trout: their fight for survival. Univ. Wash. Press, Seattle, 192 p.

Pugh, J. R., G. E. Monan, and J. R. Smith. 1970. Effect of water velocity on the fish-guiding efficiency of an electrical guiding system. Fish. Bull. 68:307-324.

Raymond, H. L. 1979. Effects of dams and impoundments on migrations of juvenile Chinook salmon and steelhead from the Snake River, 1966 to 1975 . Trans. Am. Fish. Soc. 108:505-529. (doi: https://doi. org/10.1577/1548-8659(1979)108<505:EOD $\mathrm{AIO}>2.0 . \mathrm{CO} ; 2)$

Schoeneman, D. E., R. T. Pressey, and C. O. Junge. 1961. Mortalities of downstream migrant salmon at McNary Dam. Trans. Am. Fish. Soc. 90:58-72. (doi: https://doi. org/10.1577/1548-8659(1961)90[58:MODM SA]2.0.CO;2)

Smith, J. R., and W. E. Farr. 1975. Bypass and collection system for protection of juvenile salmon and trout at Little Goose Dam. Mar. Fish. Rev. 37(2):31-35.

Swan, G. A., R. F. Krcma, and W. E. Farr. 1979. Dip basket for collecting juvenile salmon and trout in gatewells at hydroelectric dams. Prog. Fish-Cult. 41:48-49. (doi: https://doi. org/10.1577/1548-8659(1979)41[48:DBFCJS 12.0.CO;2).

Trefethen, P. S. 1968. Fish passage research, review of progress, 1961-66. U.S. Dep. Commer., Dep. Int., USFWS, Bur. Comm. Fish. Circ. 254, 23 p.

VanDerwalker, J. G. 1970. Responses of fingerling coho and Chinook salmon to modified flows in a simulated turbine intake. Trans. Am. Fish. Soc. 99:532-539. (doi: https://doi. org/10.1577/1548-8659(1970)99<532:ROFC $\mathrm{AC}>2.0 . \mathrm{CO} ; 2$ ).

Williams, J. G., and G. M. Matthews. 1995. A review of flow and survival relationships for spring and summer Chinook salmon, Oncorhynchus tshawytscha, from the Snake River Basin. Fish. Bull. 93:732-740.

and M. E. Tuttle. 1992. The Columbia River: fish habitat restoration following hydroelectric dam construction. In G. W. Thayer (Editor), Restoring the nation's marine environment, p. 405-422. Maryland Sea Grant College, College Park, Md 